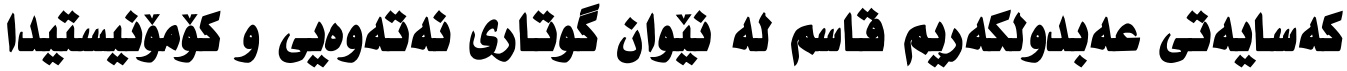

\section{سوزان كريم مصطفى}

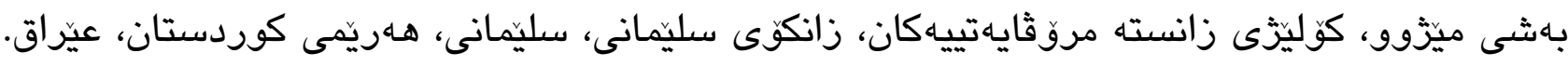

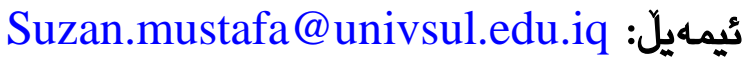

هوخته: يو:

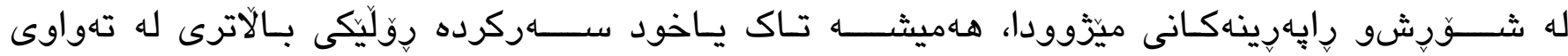

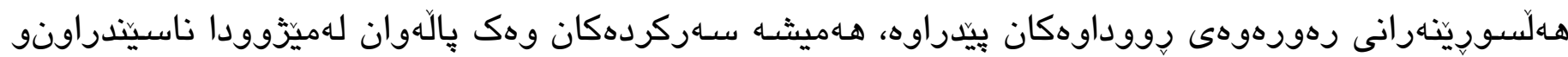

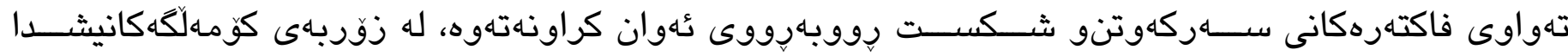

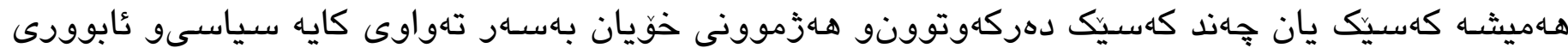

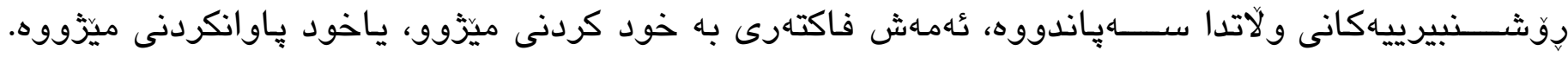

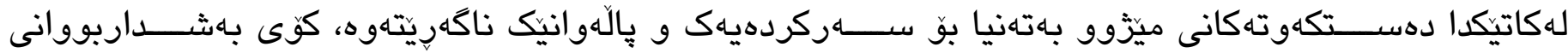

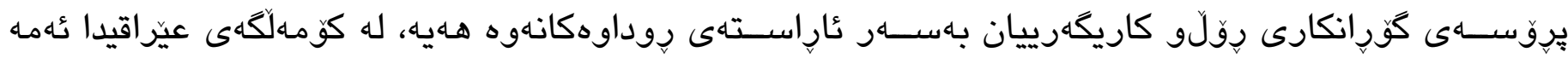

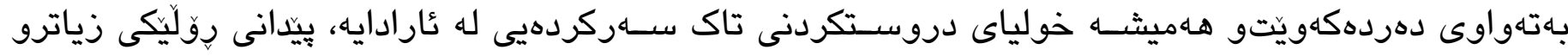

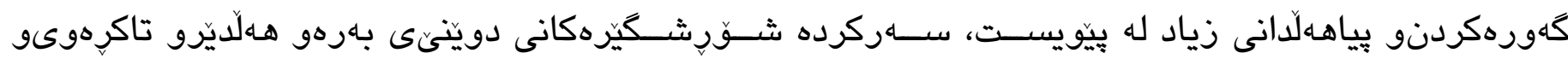
ديكتاتقرى بردووه.

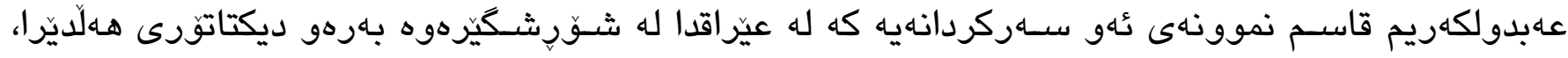

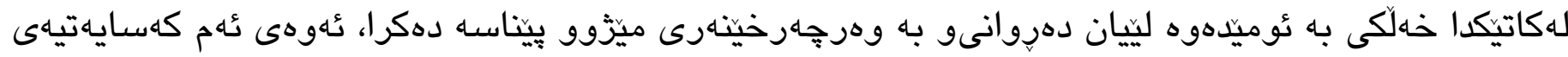

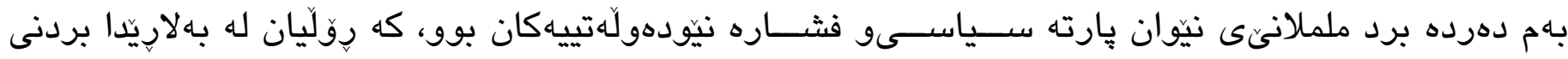

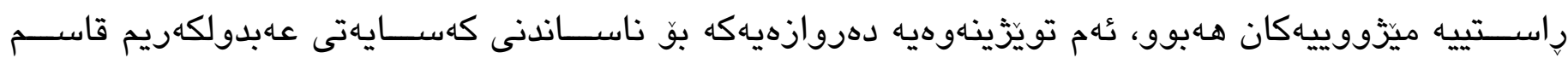

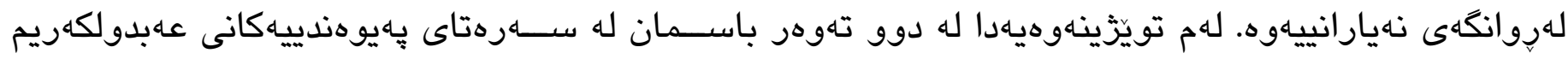

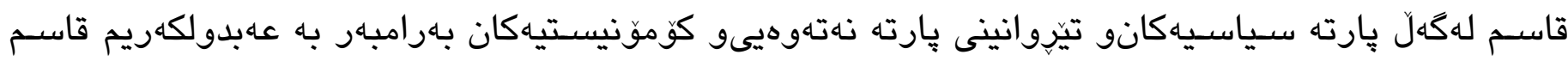

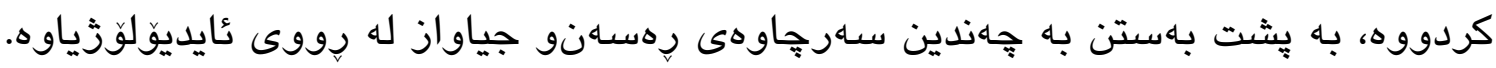

كليله وشُهكان: پِارت، شوّرشى تهمموز، عهبدولكهريم قاسم، شيوعى، ئهفسهره عازاديخوازهكان. 


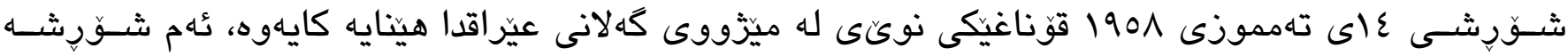

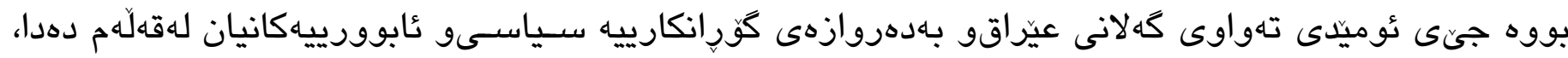

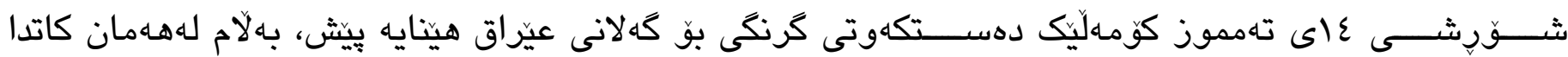

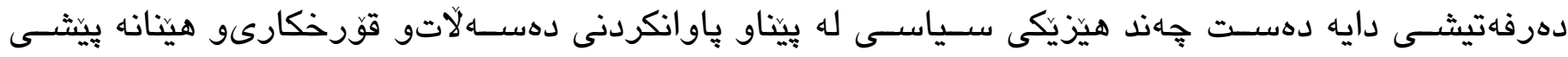

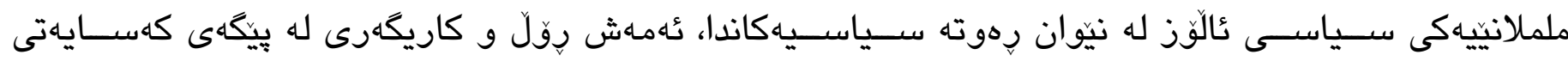

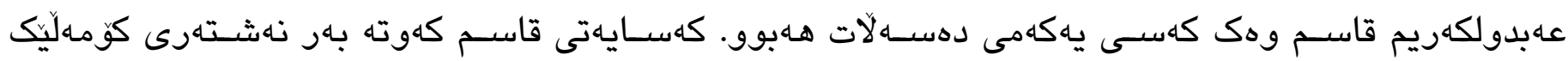

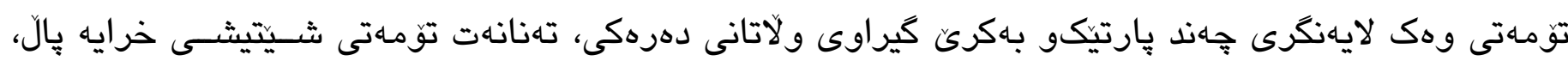

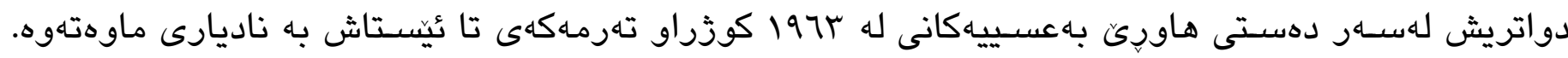

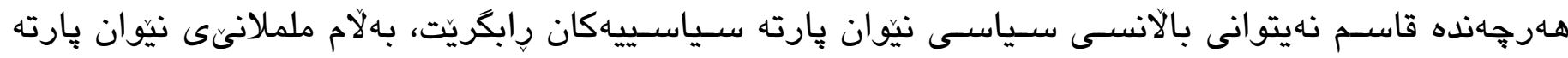

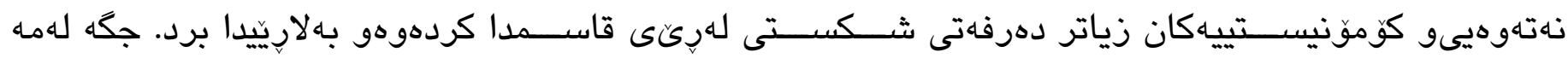

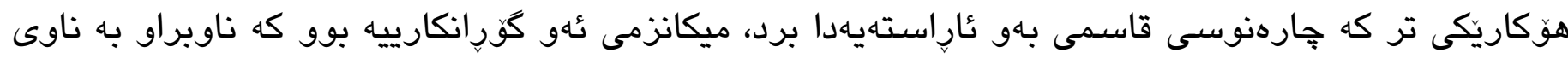

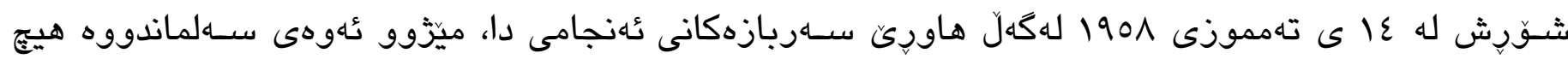

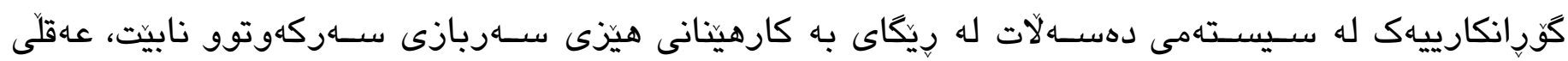
سـاربازى تواناى بـهِيْوهبردنى ولَّاتى نابيتيت.

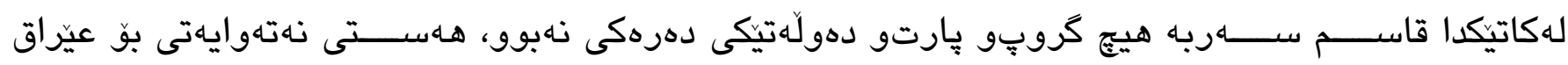

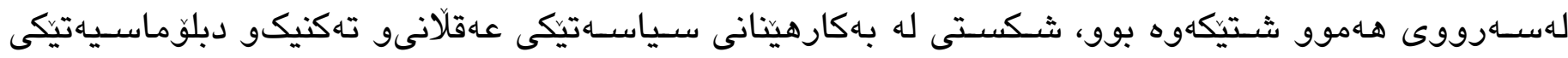
ســـاركهوتووانه بووه هوَكارى دزايهتييهكى زوّرى ناوخوّيىو دهرهكى، جياوازى نهكردن له نيّوان دوّســت و

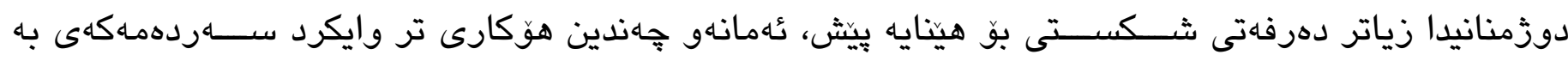

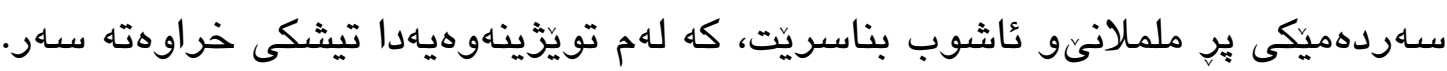

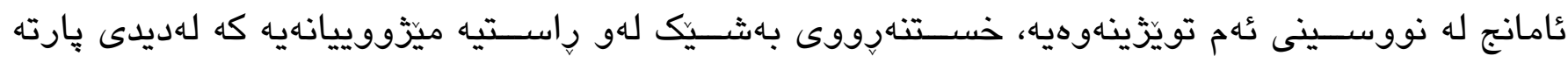

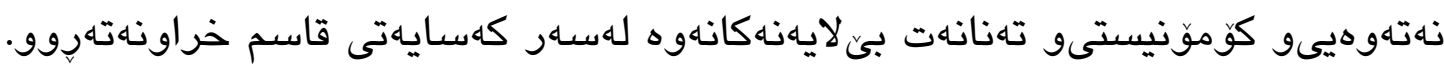

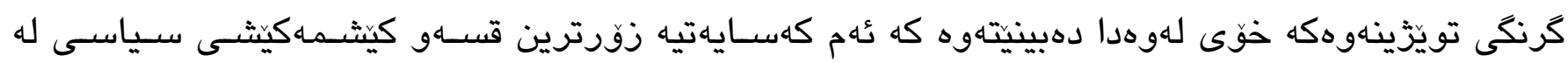

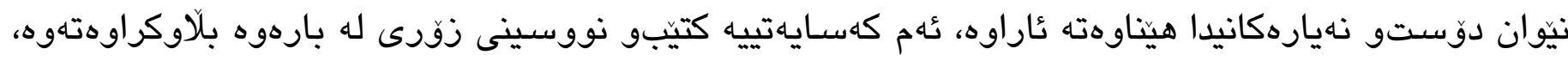

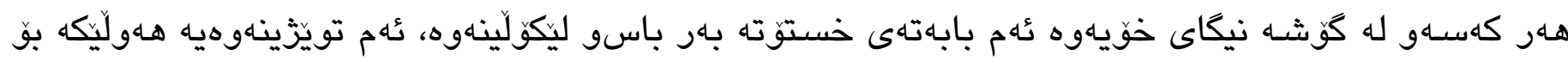
خستناهووىى لايهنه دروستو ناكوكهكان له يِيكهاتهى كهايانتى قاسمدا.

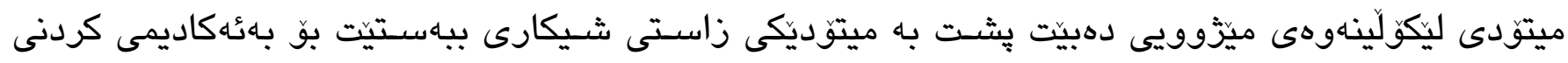

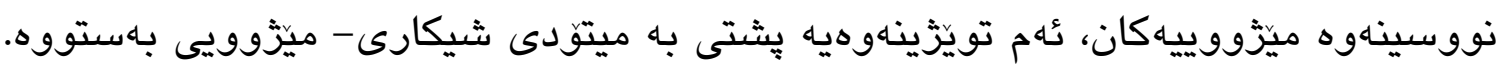

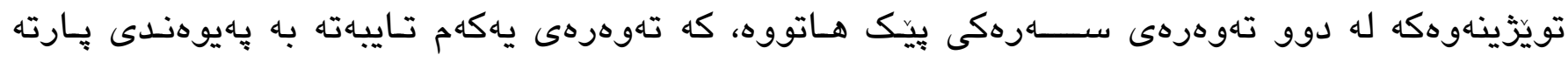

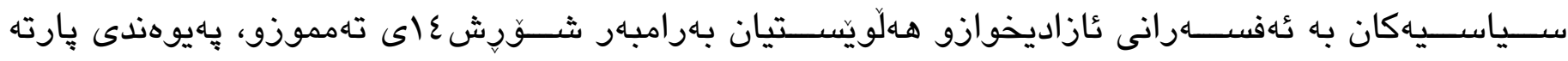




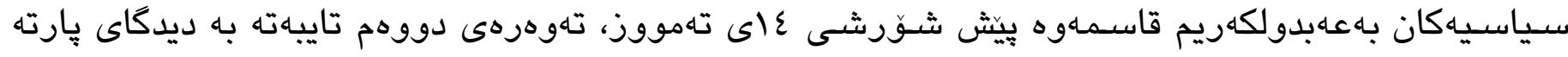

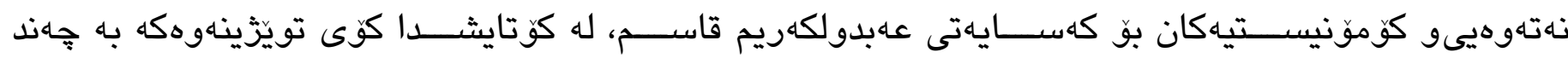
تئهنجاميكِ خراوهتهروو.

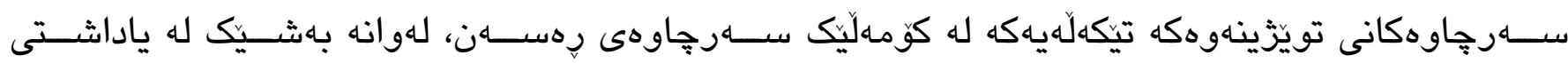

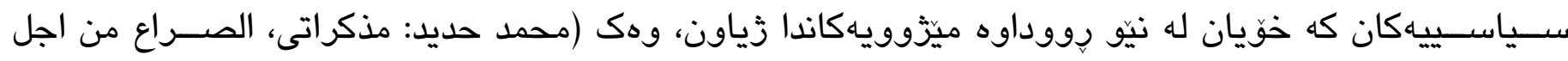
الديمقراطية في العراق، مسـعود بارزانى: بارزانىو بزوتنهوهى رزكاريخوازى كورد، سـيف الدين الدورى: علي هـالح السـدي، نائب رئيس الوزراء و وزير الداخلية و سـلطة البعث الاولى في العراق ب79 (1) هـهووها وتهكانى عهبدولكهريم قاسـم كه له كوبوونهوه جياوازهكاندا خستونيهتيهروو، (ماجد شبر: خطب الزعيم عبدالكريم قاسـم 1901- 1909، مبادىء الثورة عا تموز في خطب ابن البار الزعيم عبدالكريم قاســـ 1909) هـروهها بهاشــيكى

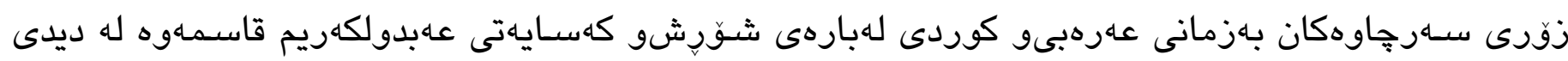
نوســـره بيانىو عهرهبييهكانهوه نووسـراون، وهك(فيبى مار: ميّزووى نوكنى عيّراق، د.طه ناجى: ثورة العراق المجيدة عاى تموز 1901 و الرهان علي العسكر، د. فاضـل محمد حسين البدراني: الفكر القومى لدى الاحزاب و الحركات السياسية في العراق خلدون ساطع الحصرى: ثوره عا تموز و حقيقة الثيوعيين في العراق).

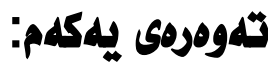

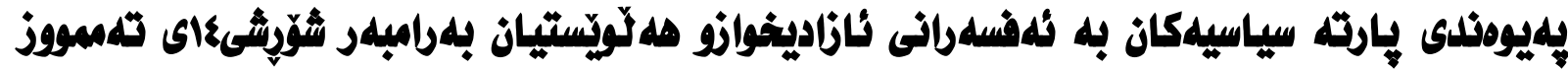

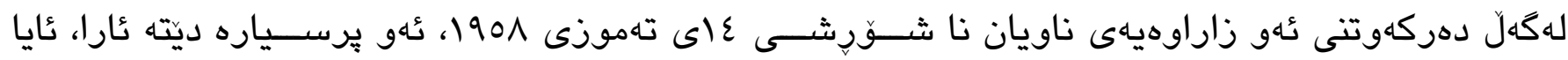

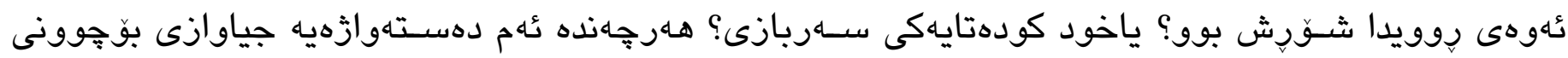

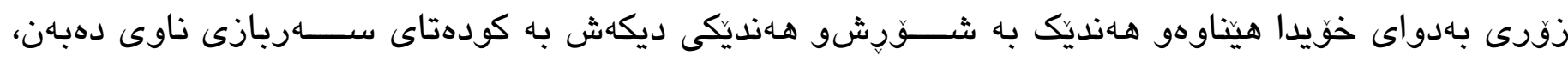

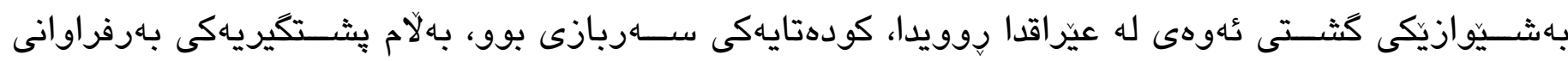

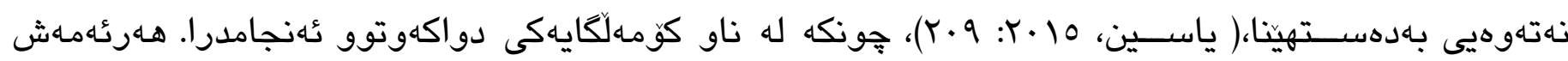

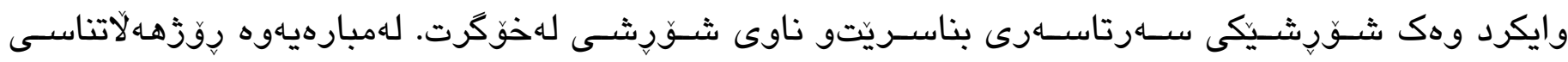

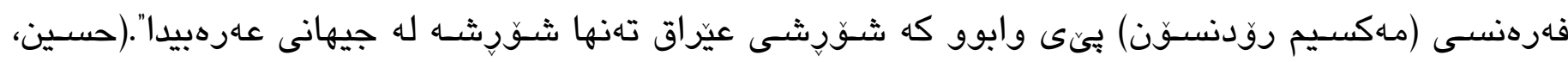

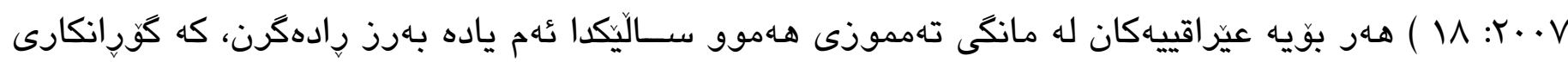

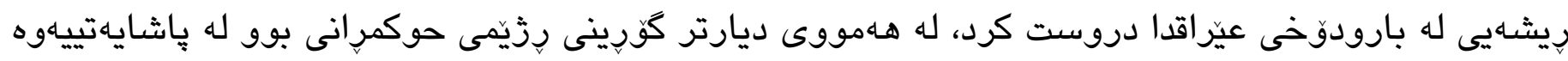

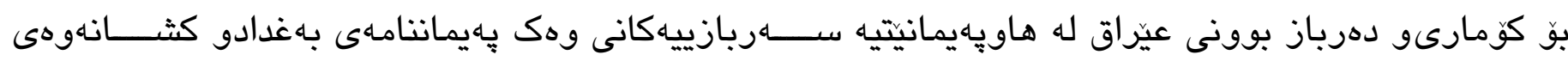

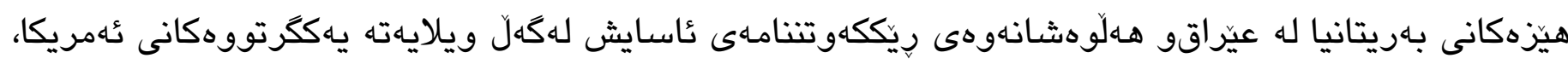

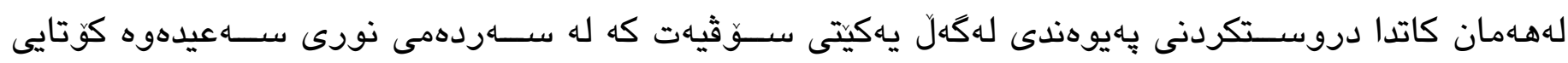




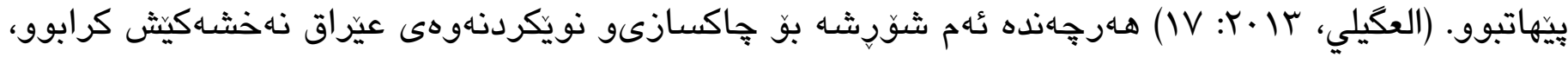

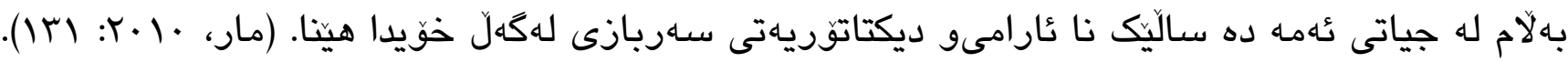

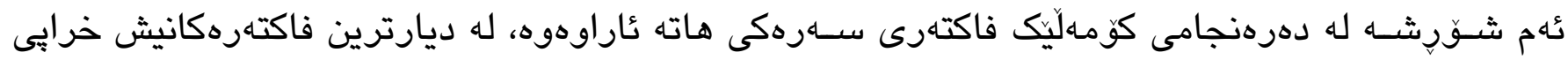

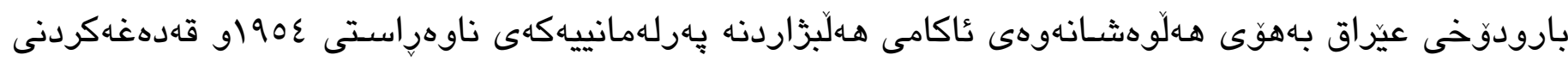

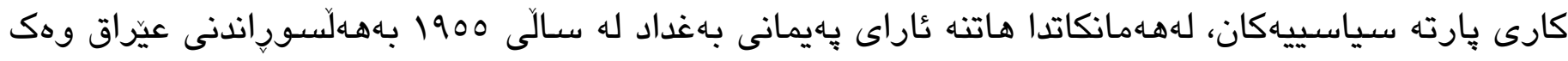

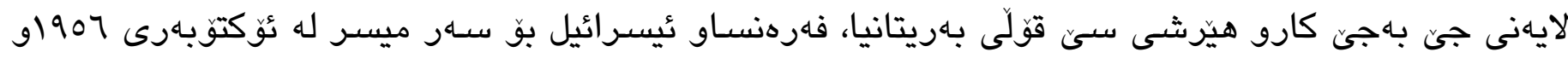

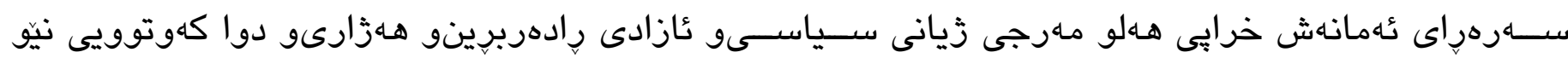

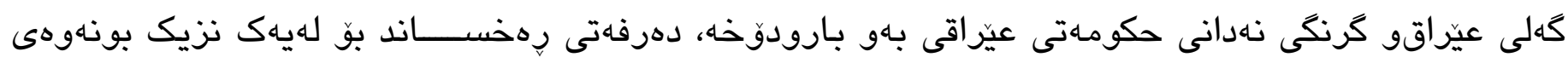

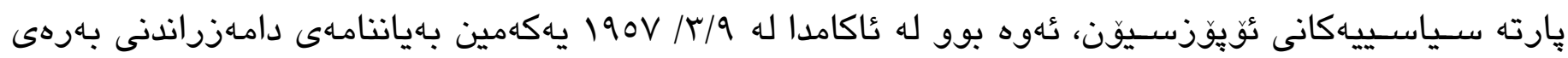

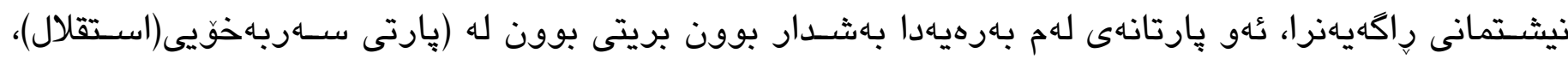

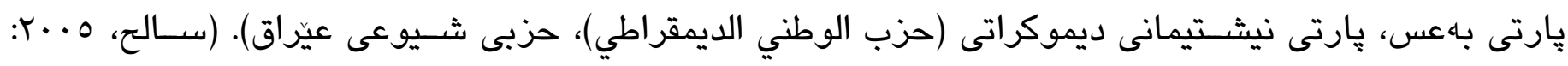

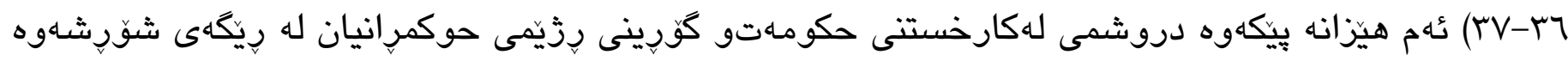

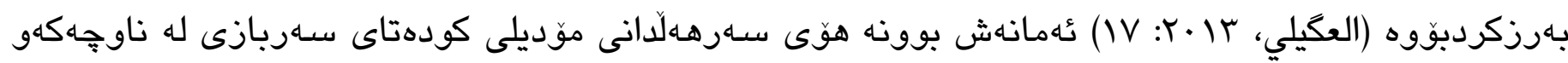
كاريكَرى كودتاكهى سالّى به الى جهمال عهبدولناصرى ميسريان بهسهردوه بوو. له ئهنجامى ئهو بارودوخه

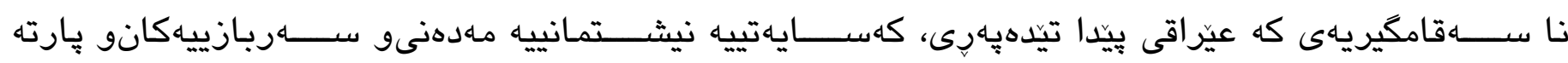
نيشتمانييهكان دهستيان به يِهيوهندى كرد، بوّ را كُورينهوهو رِيككهوتن سـهبارهت بهو باردوخهى كه له عيّراقدا

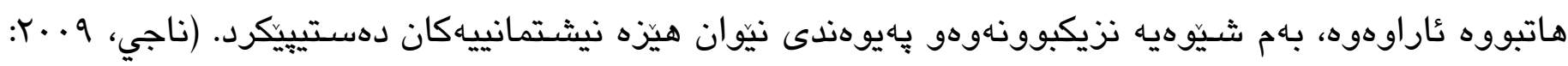

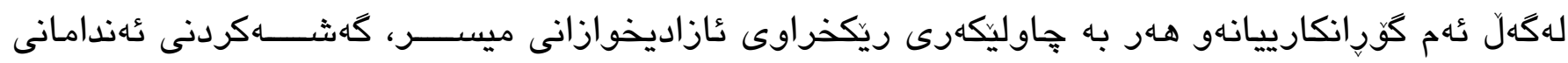

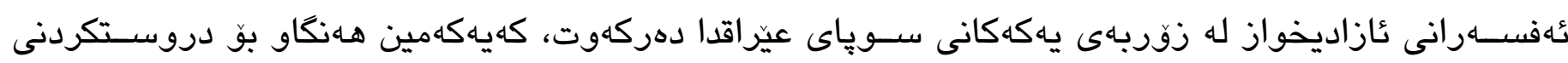

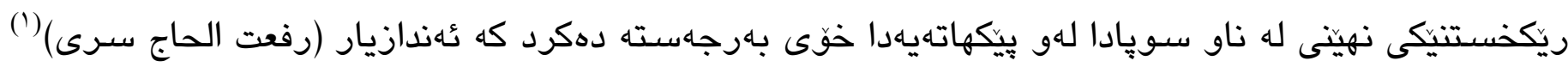

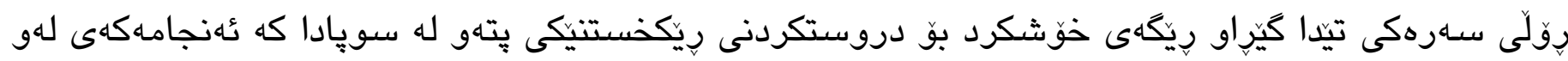

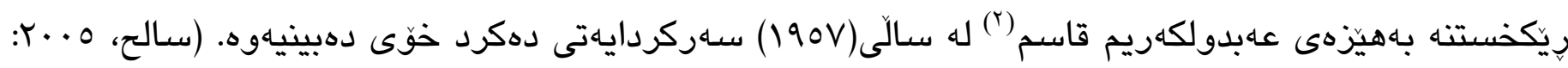

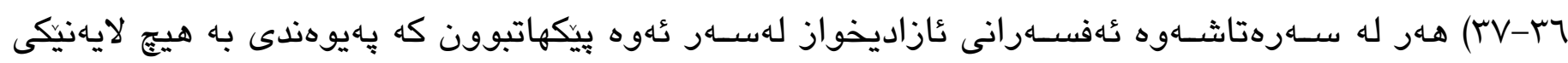

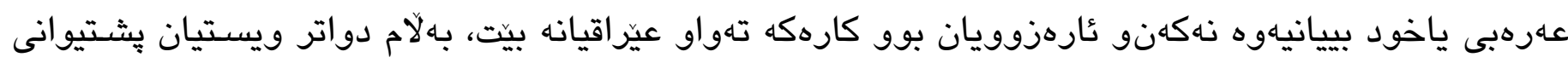

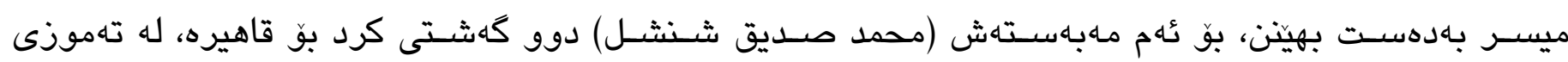

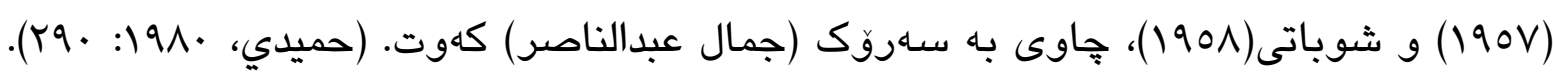

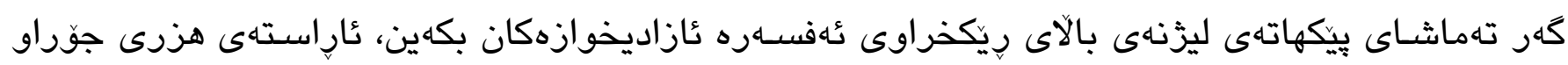

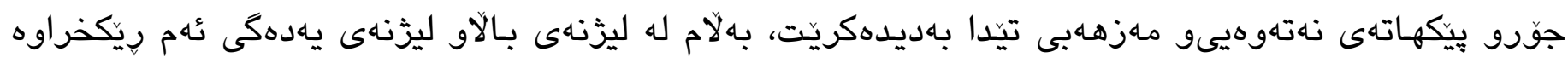

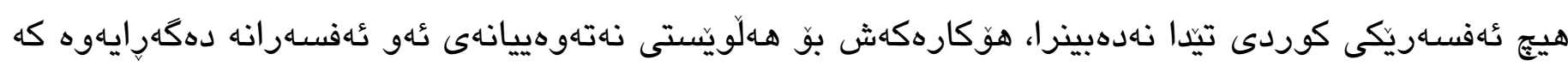




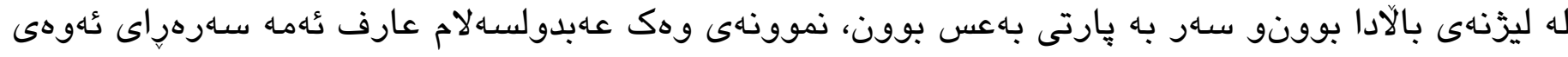

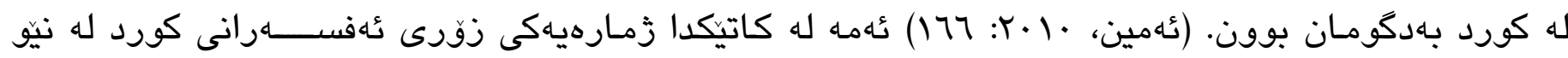

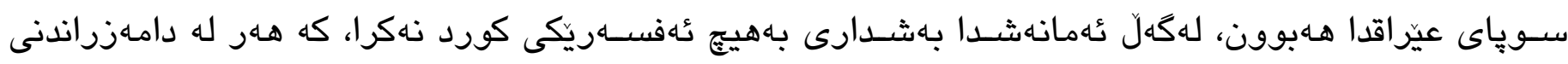

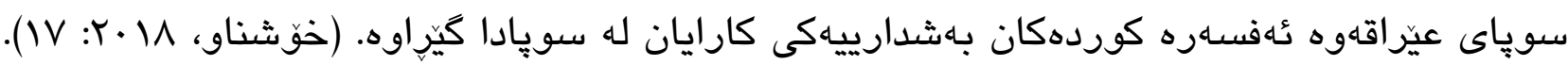

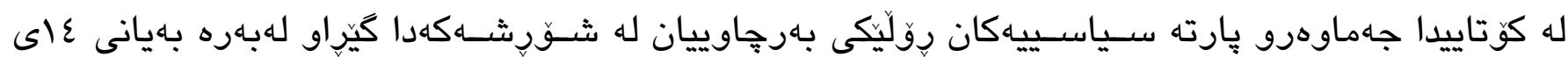

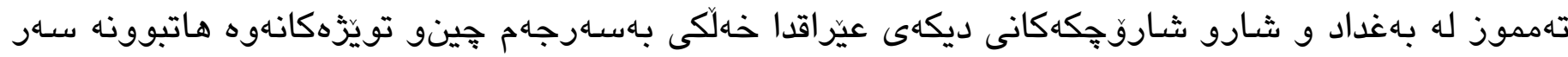

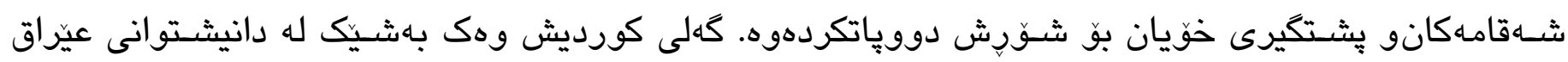

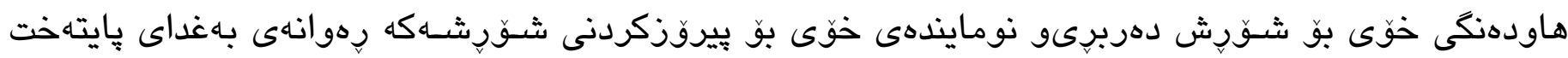
كرد. (ئهمين، · •l • (IV)

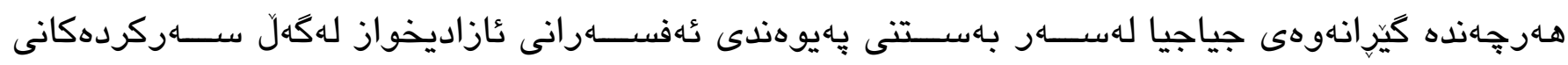

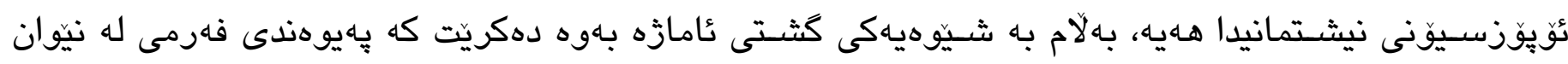

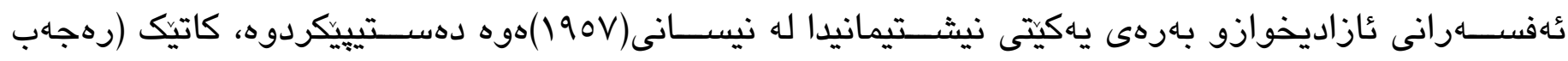

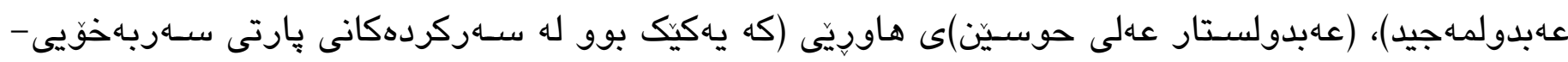

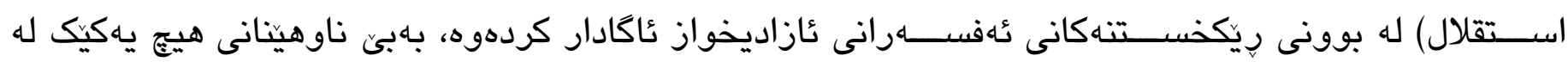

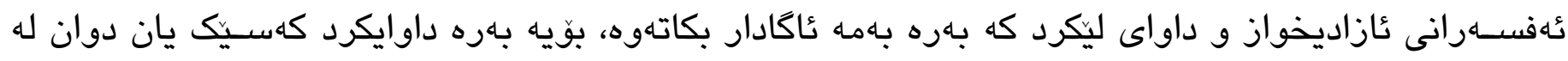

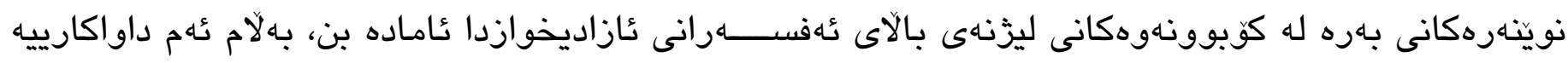

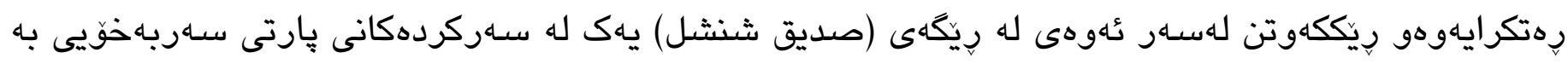

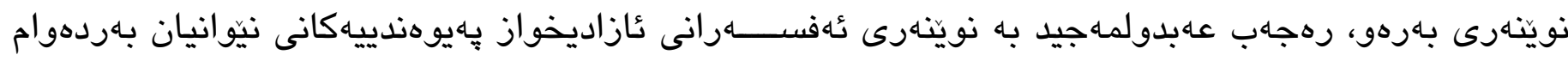

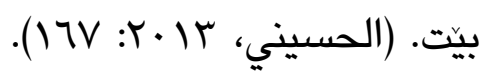

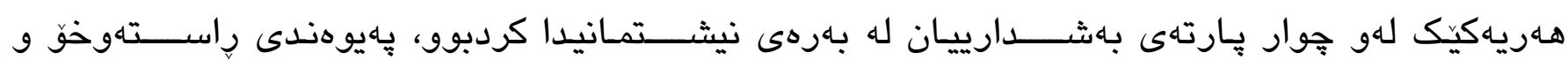

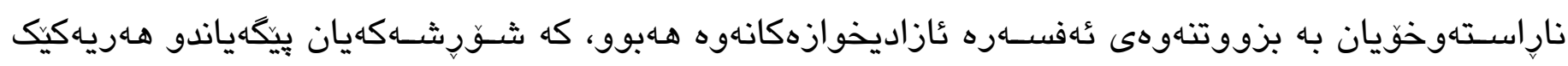

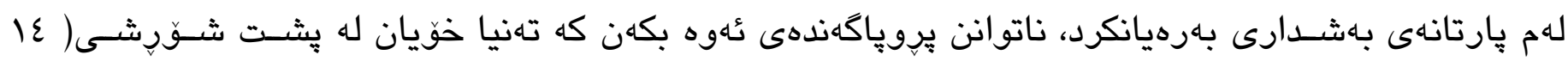

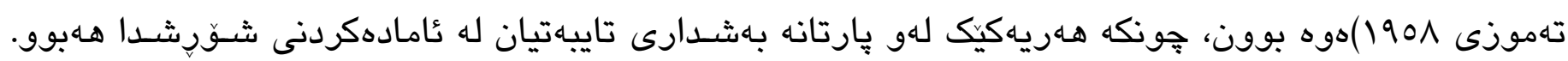

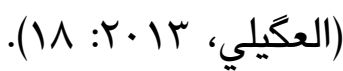

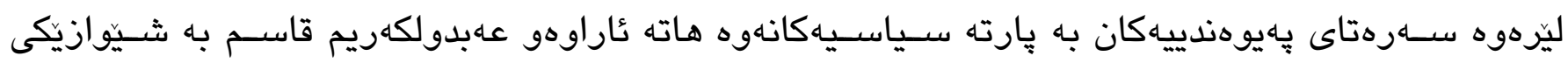

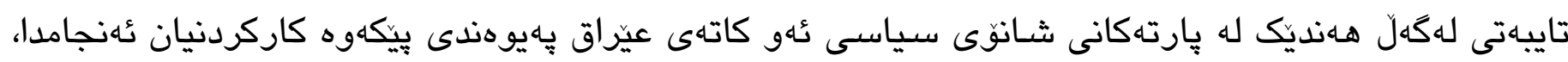
له يِيناو بهدهستهينانى يشتيوانييهكى زياترى شوّرشو ئامادهارييهكى باشتر.

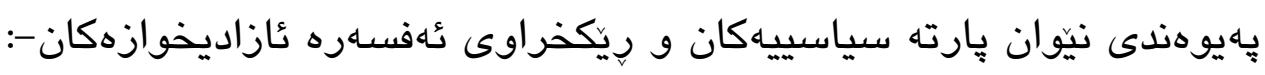




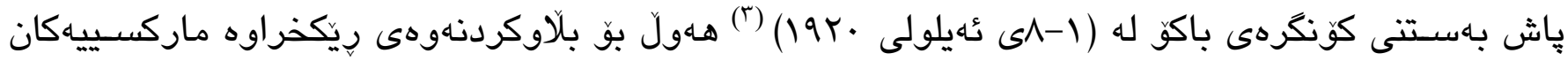

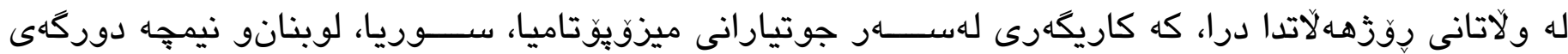

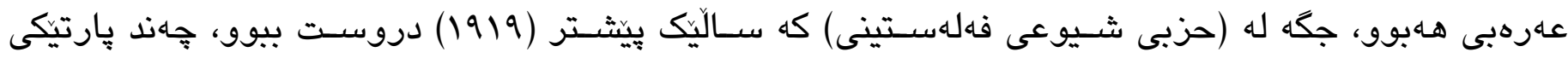

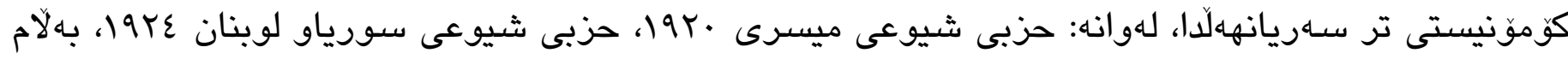

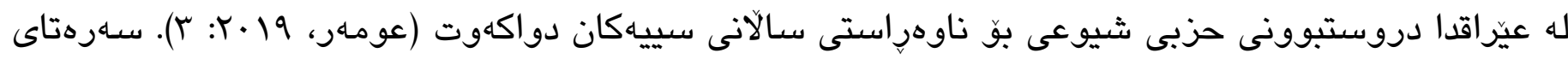

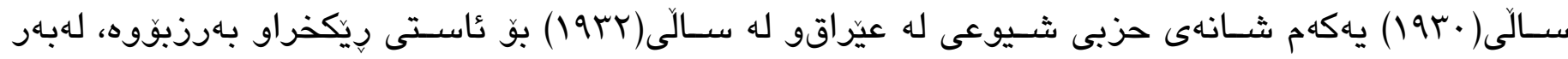

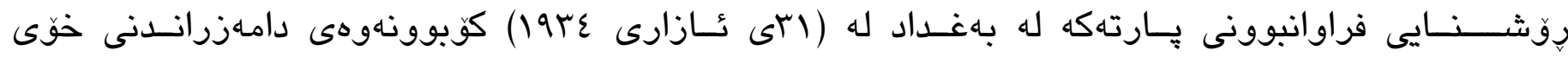

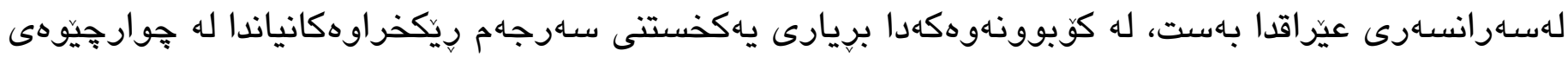

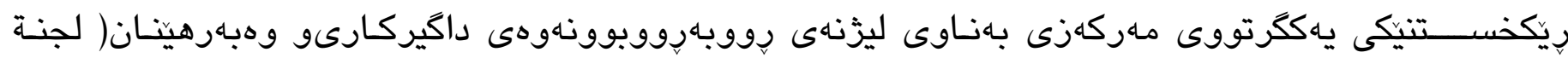

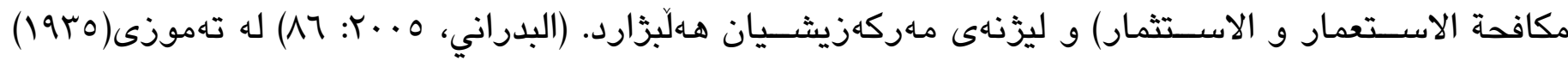

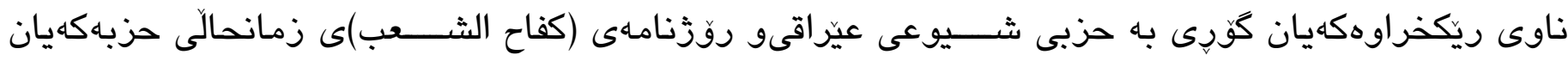

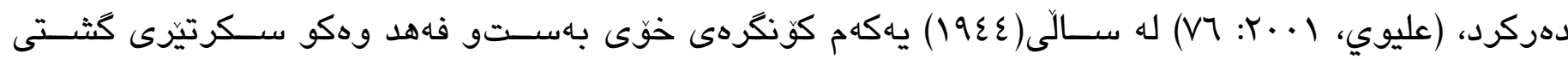

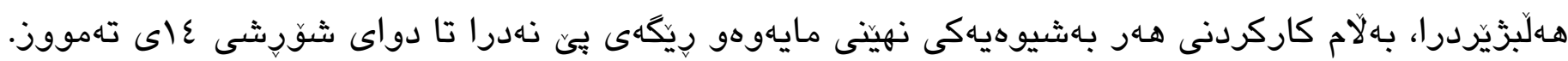

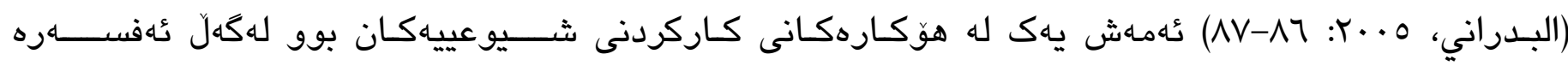

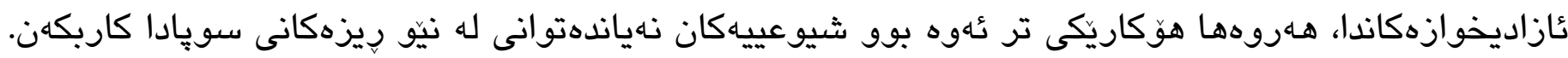

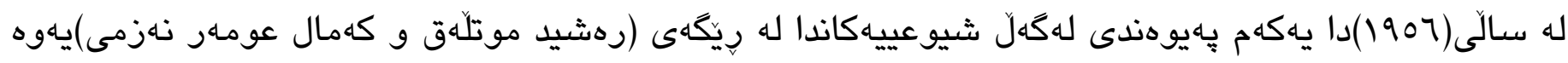

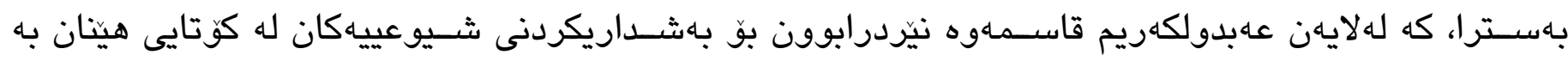

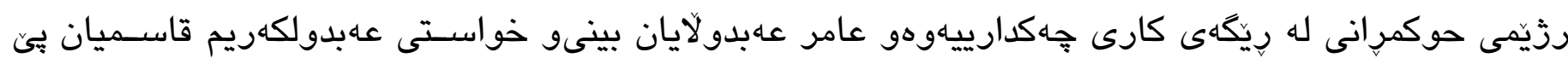

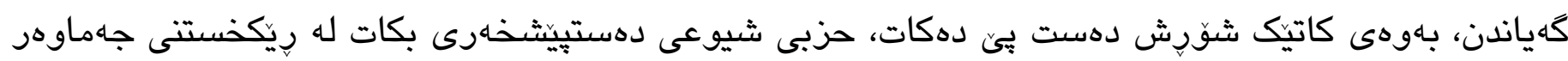

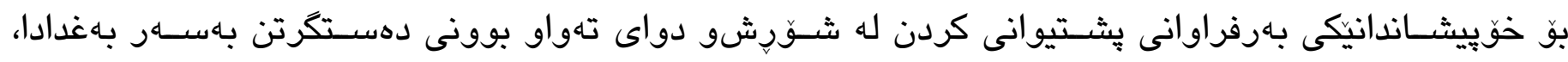

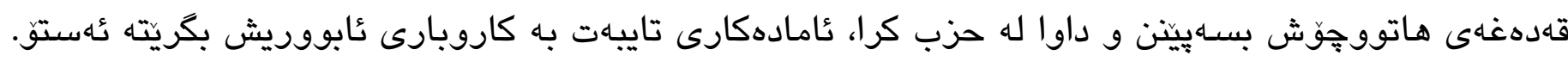

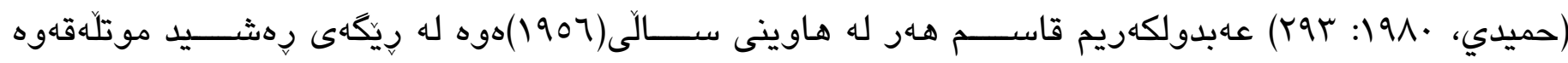

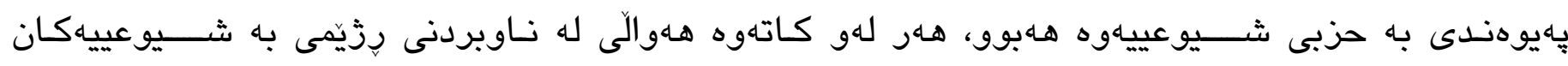

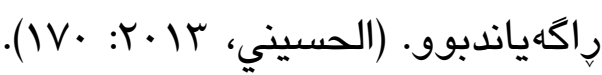

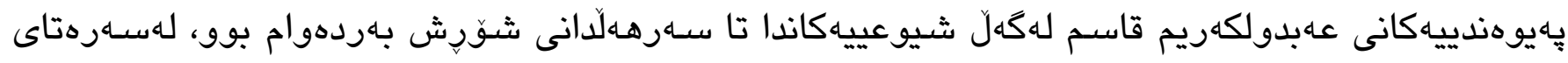

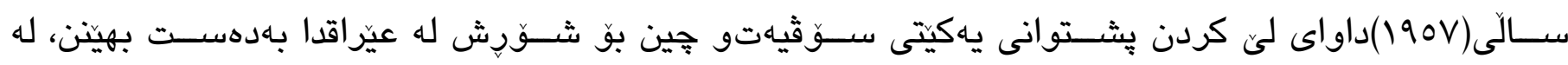

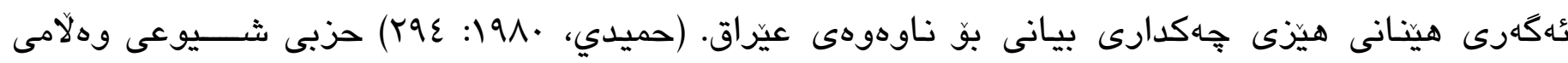

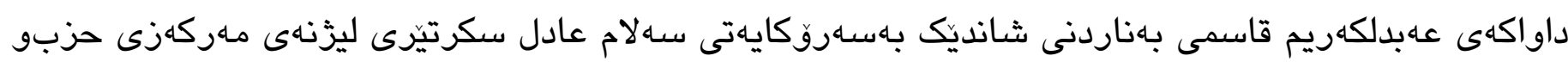

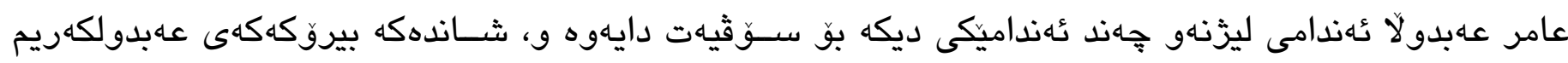




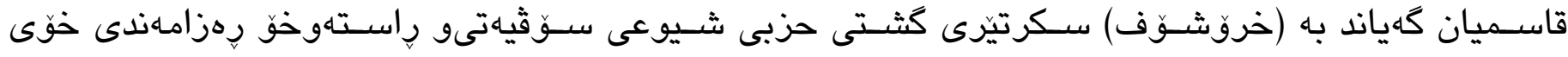

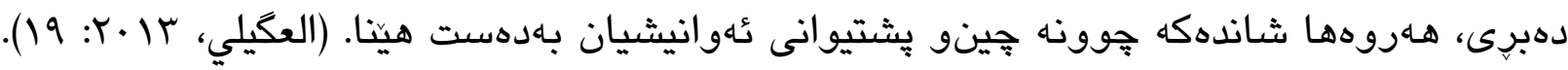

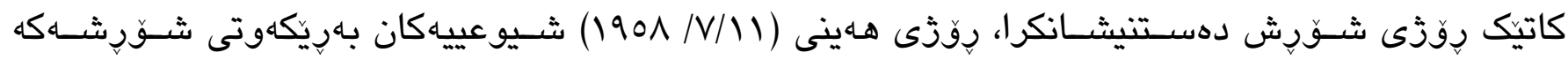

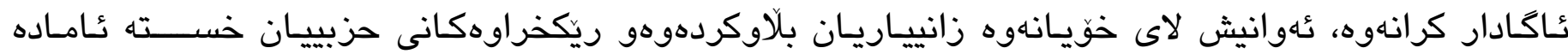

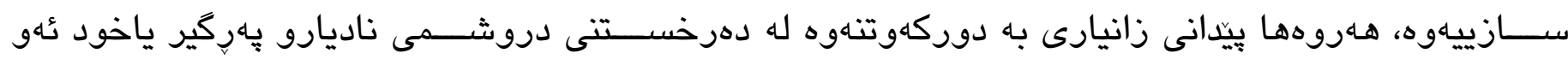
دروشمانهى كه دهبنه هوَى يِيروزكردنى عاهو سـاركردانهى سـهروكايهتى بزووتنهوهى نيشتمانى، ياخود عارهبى

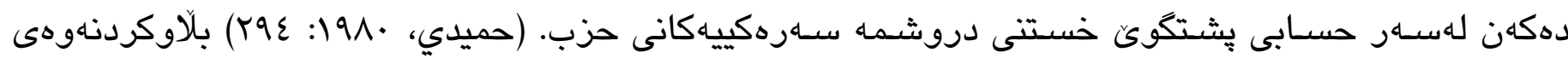

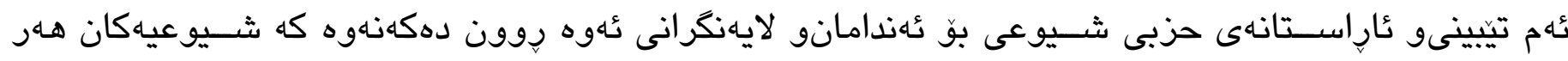

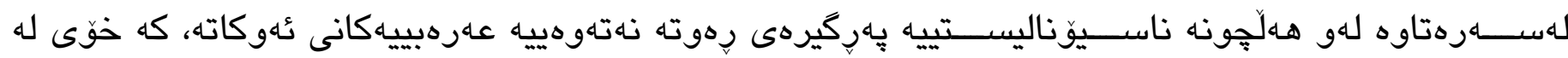
رهوتى ناسرييهكانو بهعسييهكاندا دهبينيهوه و كهوتبوونه مهترسيهوه، دهرهنجاميش مـترسييهكهيان به راست

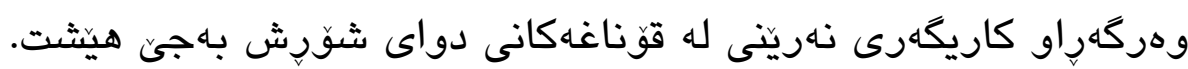

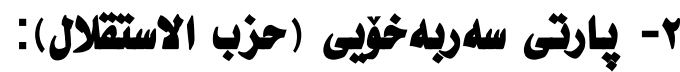

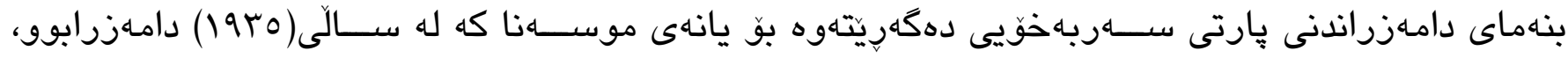

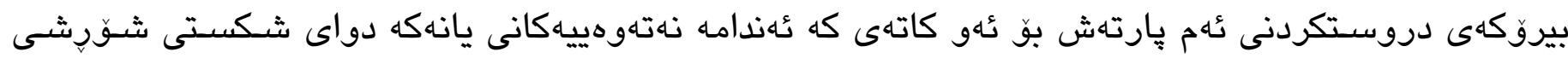

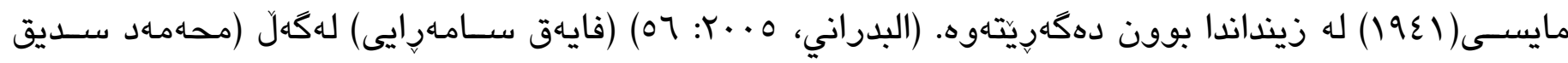

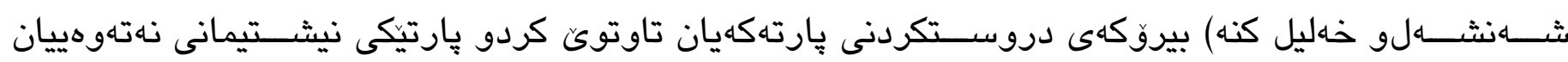
دامهزراند، جكَه لهو سـى كهـسـى ناويان هاتووه، هـريهك له (داود سـهاعدىو ئيسـماعيل غانمو فازل موعلهو

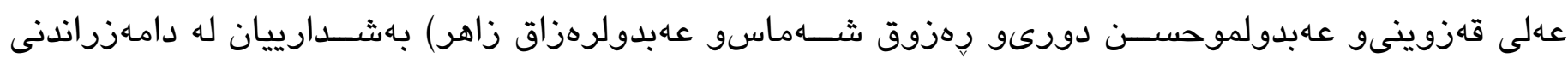

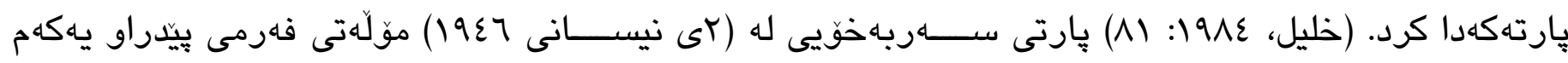

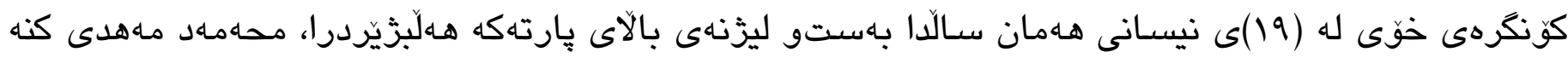

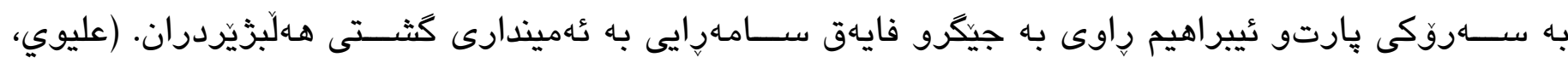

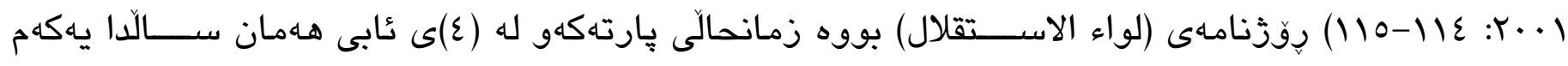

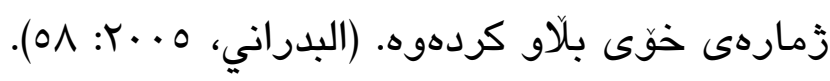

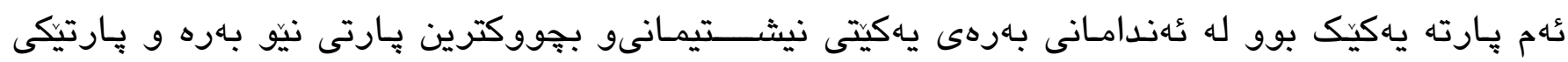

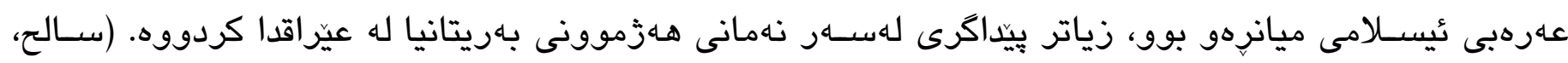

. (rV: Y.०O

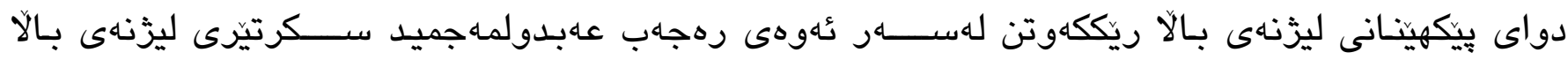

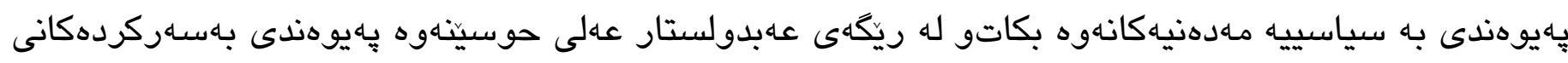

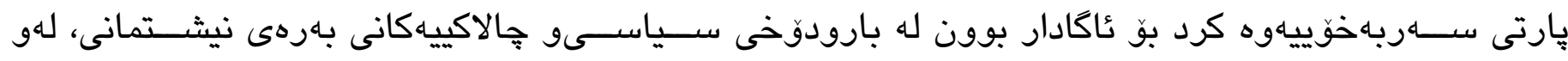




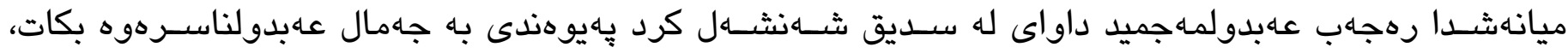

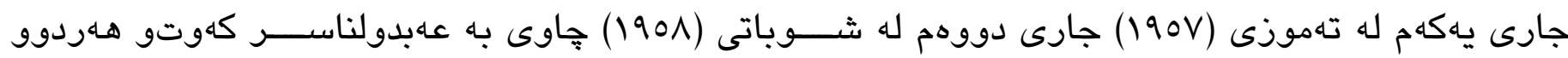

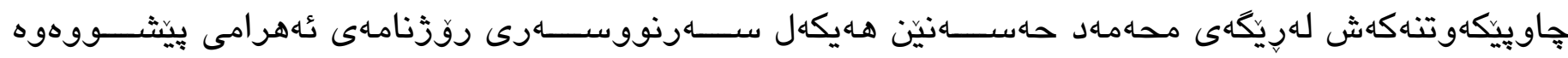

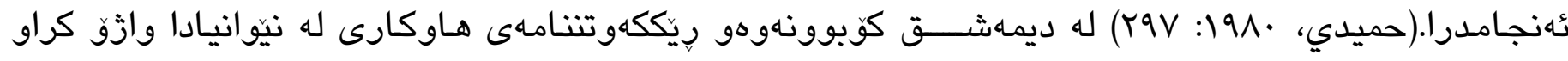

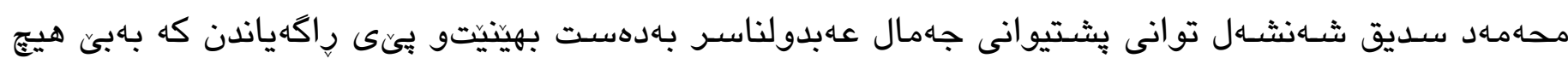
دوو دلّييه لهيال ئهنجامدهرانى كودهتاكهدا دهوهستيت. (محمد، محمد، 19 • ب: عَr). هـروهها كاتيك رهفعهت حاج سـرو رِهجهب عـبدولمهاجميد لهيهكهم رِيكخستنى ئهفسهره ئازاديخوازهكاندا

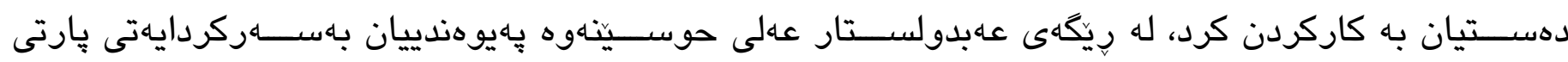

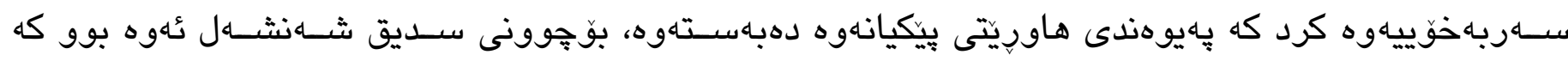

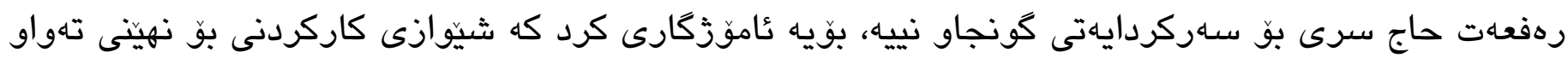

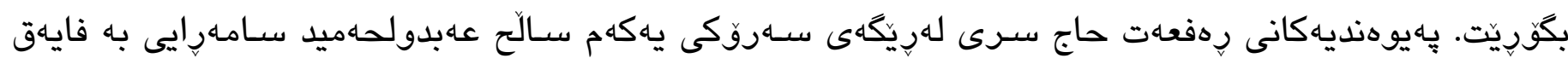

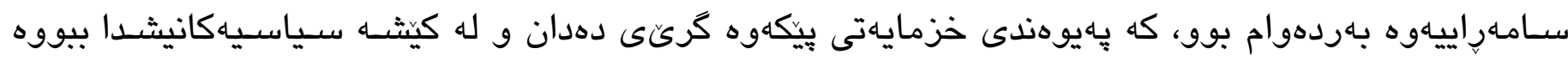
راويّزكارى. (حميدى، • • (191:

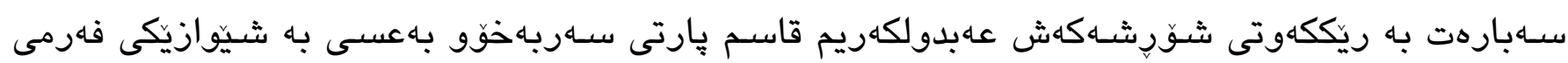

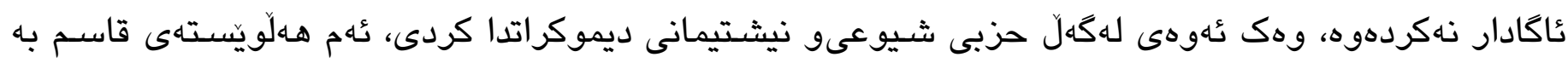

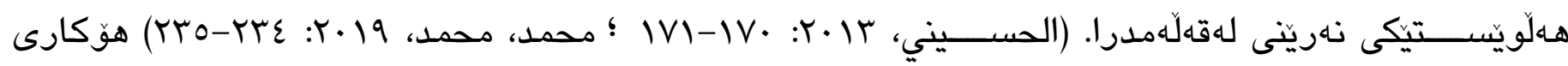

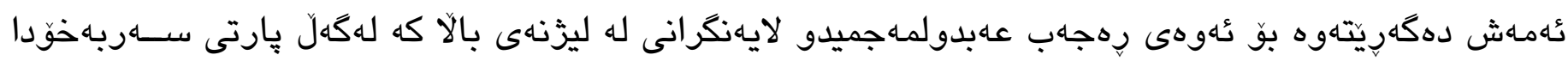

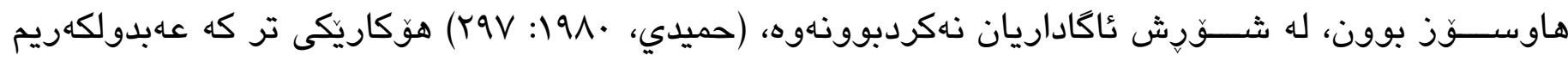

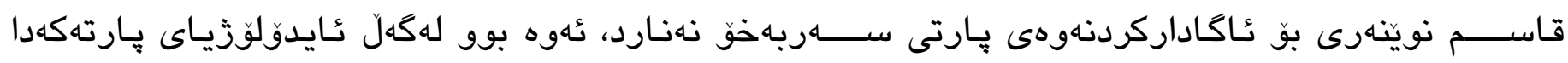

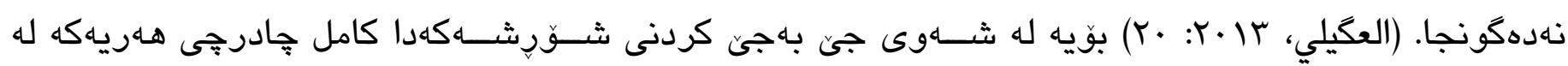

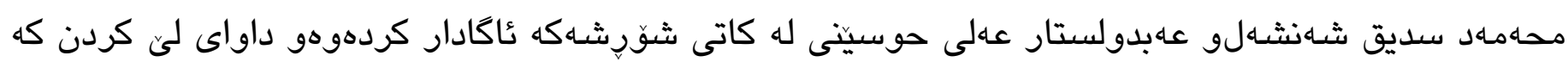

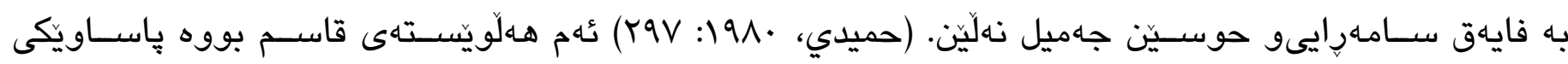

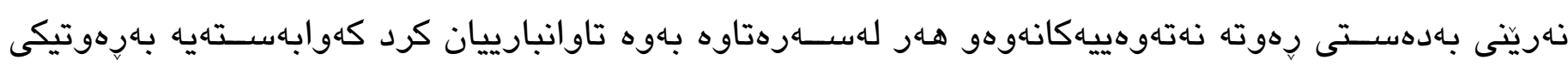
ديارى كراوهوه.

\section{ץ--هارقى ثيشتيمانى ديموكراتى (حزب الوطني الديعقراطي)}

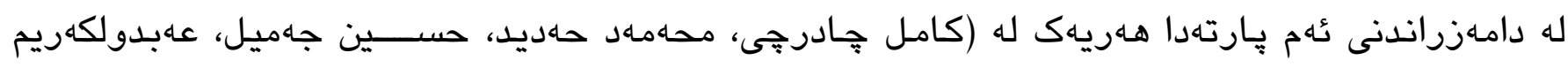

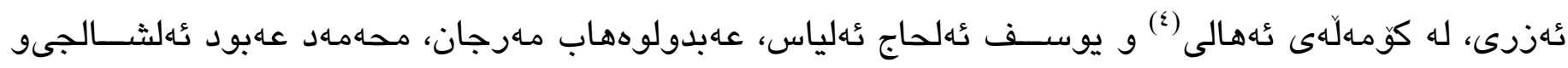

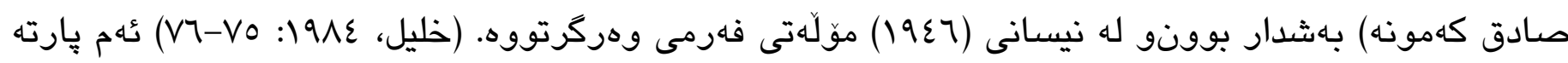

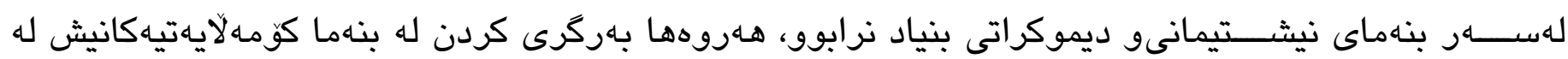


عامانجه سـهرهكييهكانيان بوو، بهلاّم زياتر جهختى له بنهماى ديموكراتى دهكردهوه وهك له باره كومهالاّيهتييهكه.

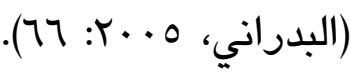

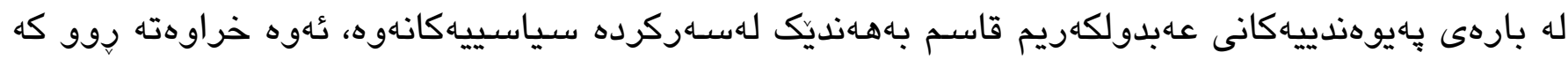

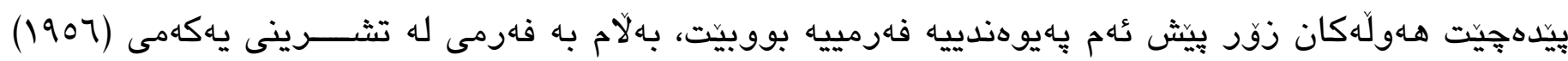

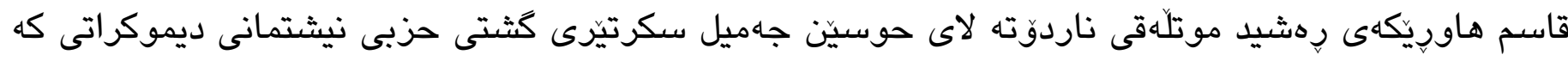

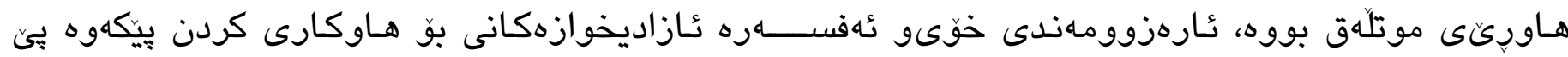
راكَياندووهو دهلّيت: حوسـينِ جهميل بوّ موتلّهقى رِوونكردوّتهوه كه كودهتا لهوانهيه هـنديَّك لهو بارودوخهى

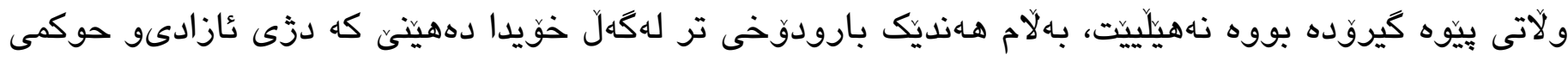

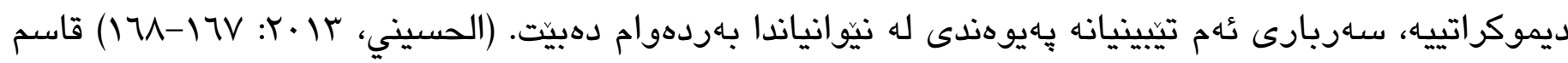

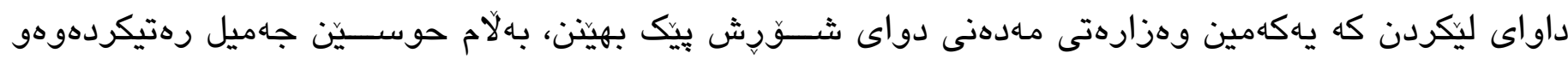

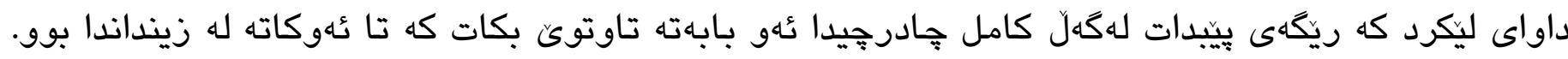

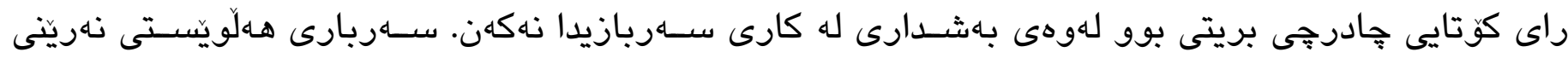

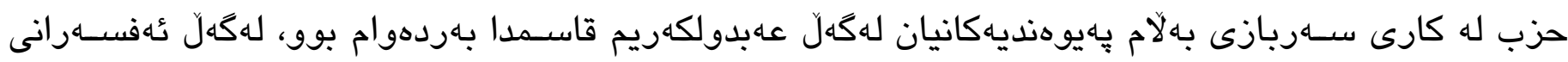

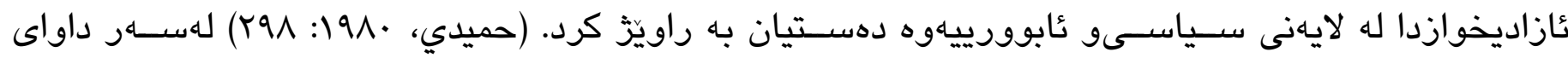

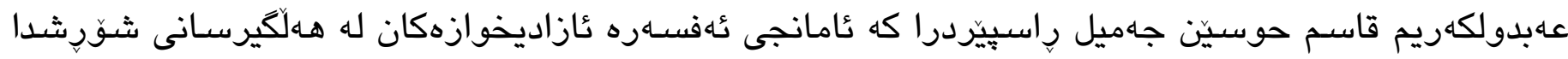

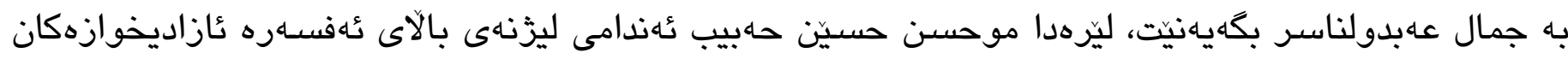

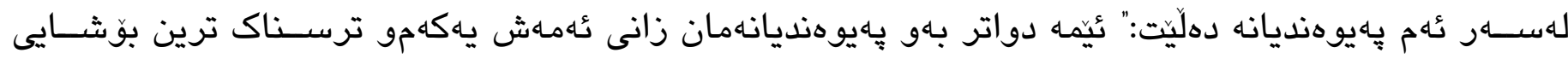

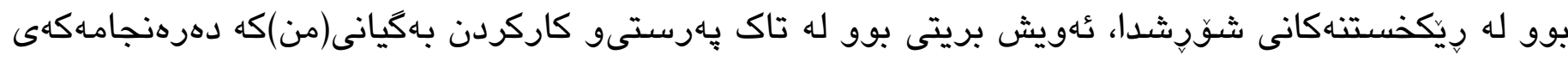

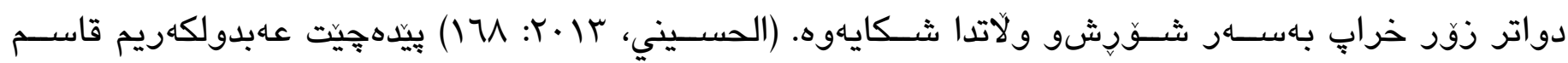

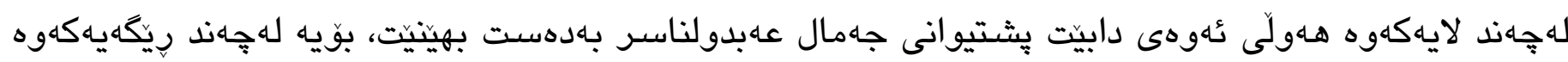

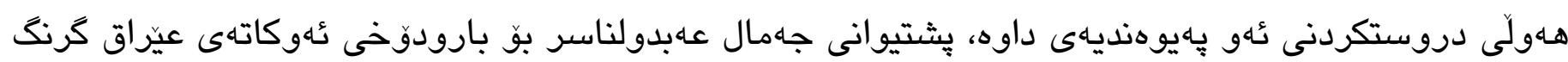

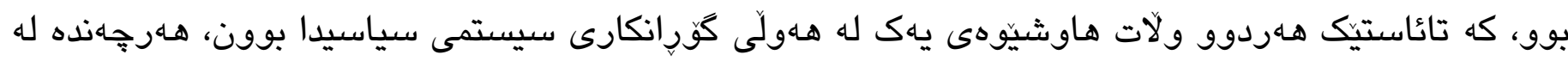
ميسر كُورانكارييهكان يِيشتر تُهنجامدرابوون.

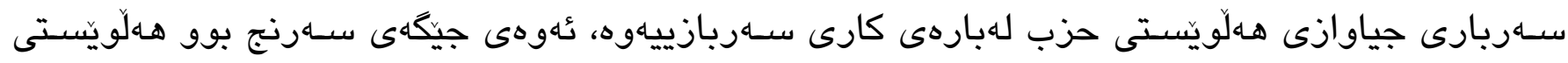

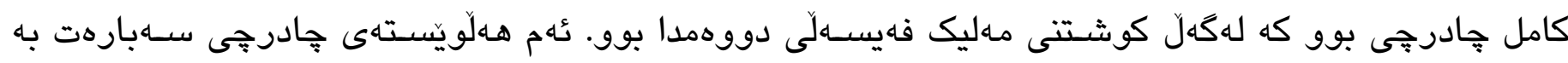

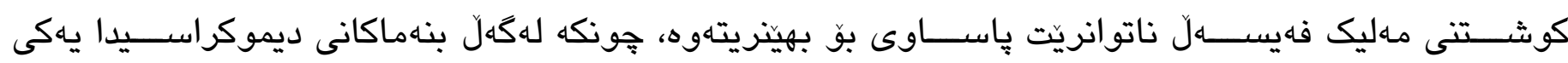

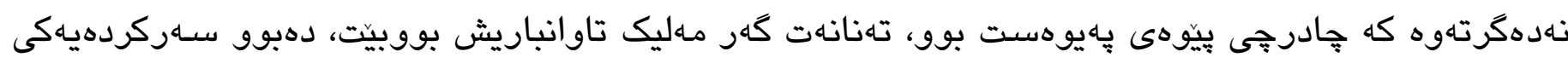
ديموكراسـى خواز يِيثـنيارى ثُهوهى بكردايه بو دياريكردنى جارهنووسى مهليك رهوانهى دادكا بكريّ. (جعفر حميدي، •(191: (191). 


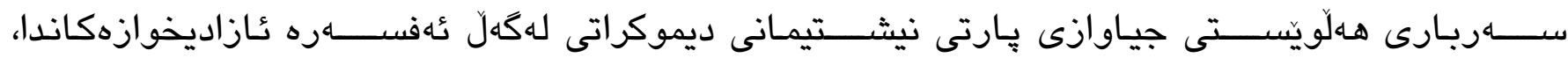

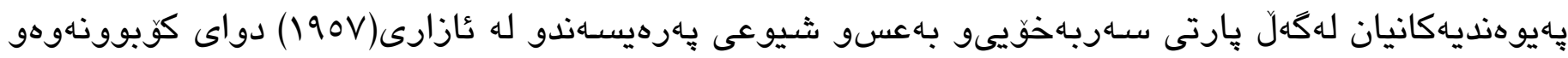

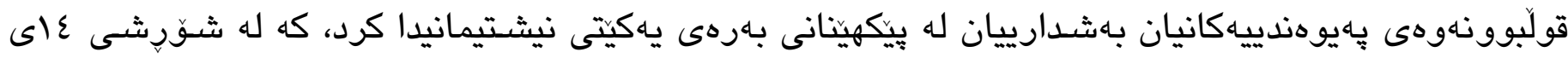
تهمموزدا بهشدارييهكى كاراى له ريِيهرى كردنى جهماوهريدا هـبوو.

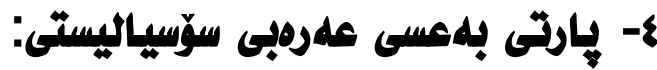

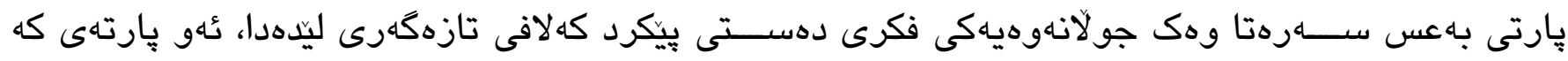

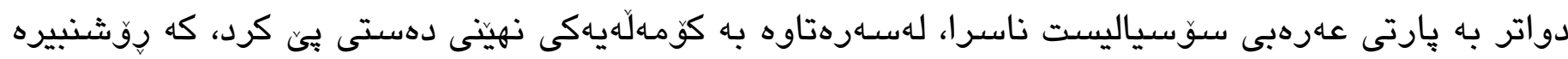

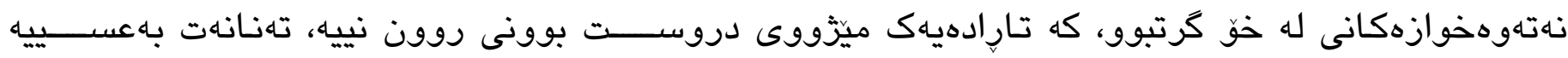

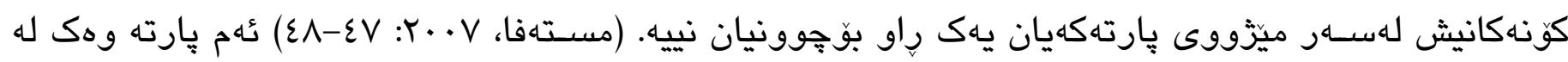

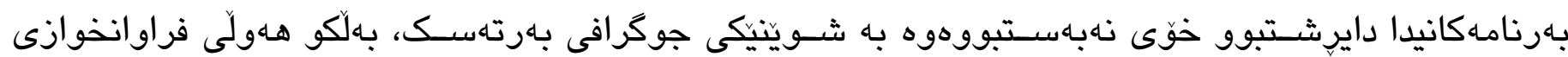

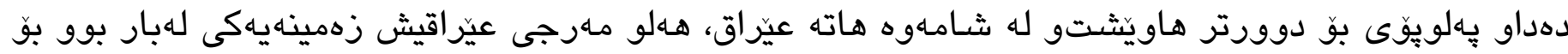

تهشهنهكردنى رِيكخستنهكانى حزبى بـاعس. (مستهفا، (1) • (190)

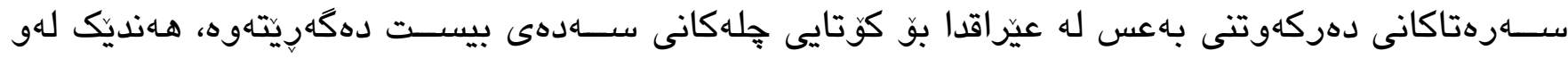

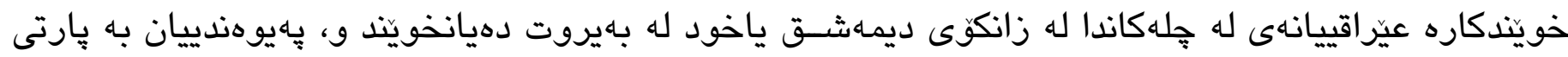

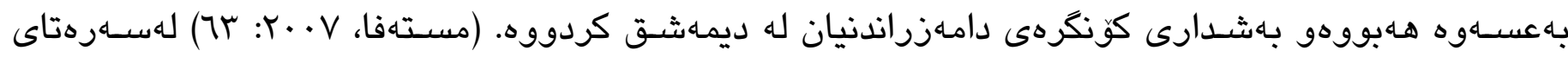

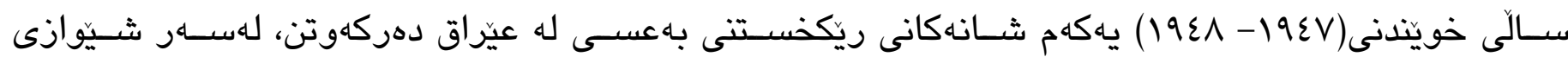

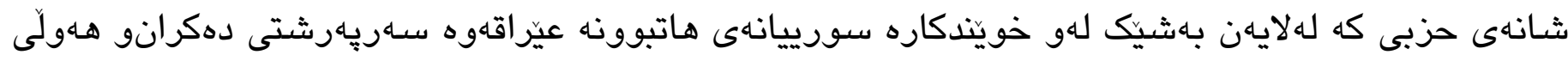

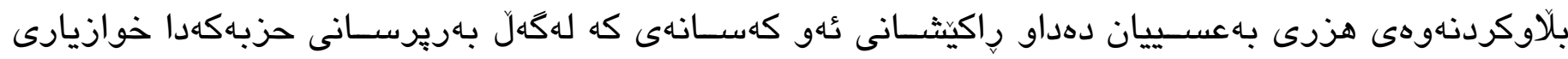

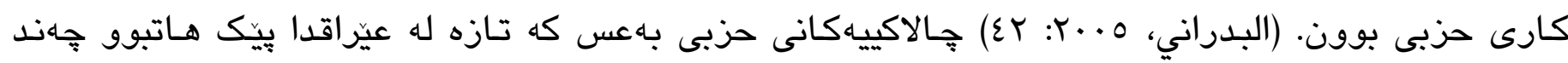

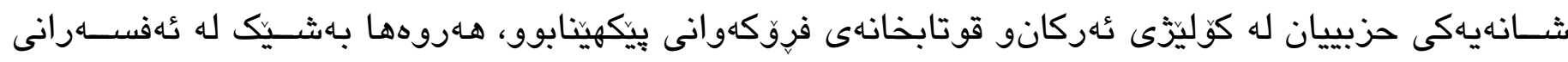

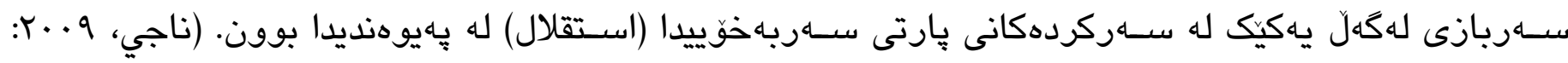

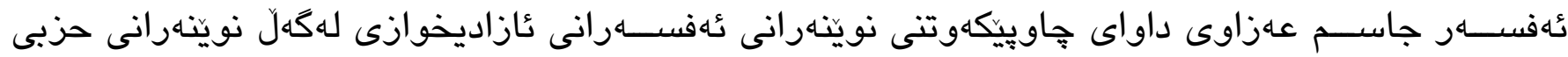

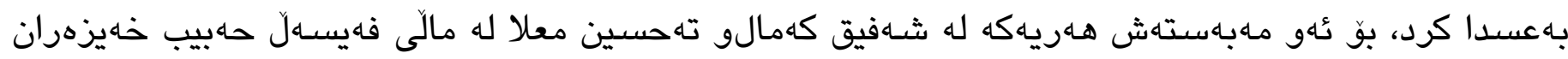

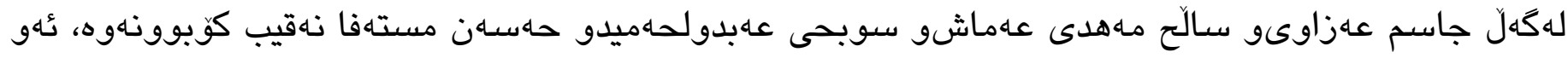

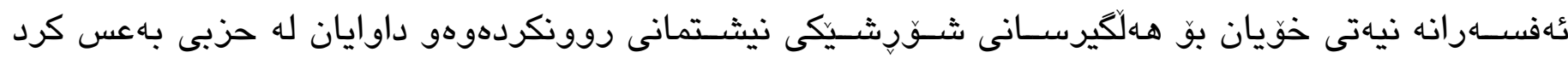

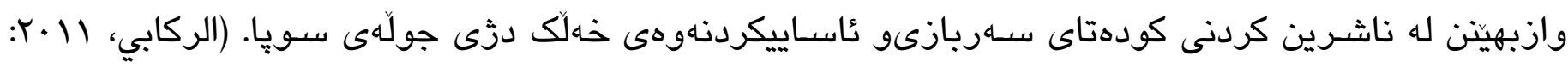

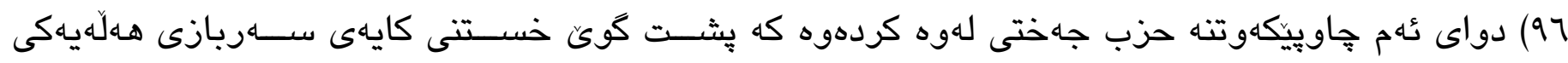

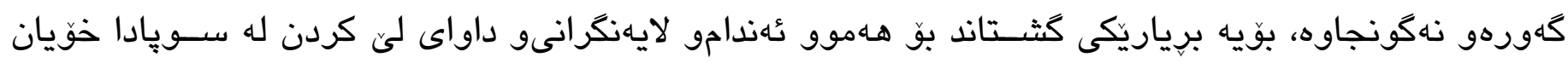




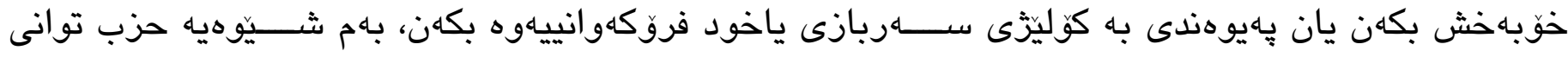

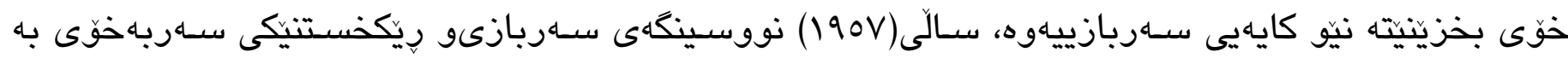

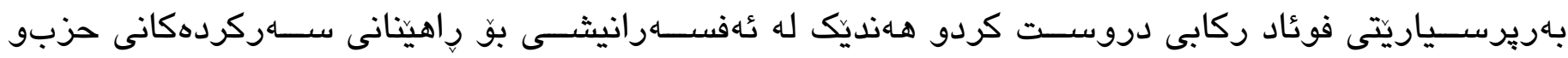

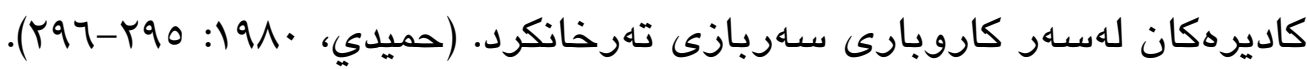

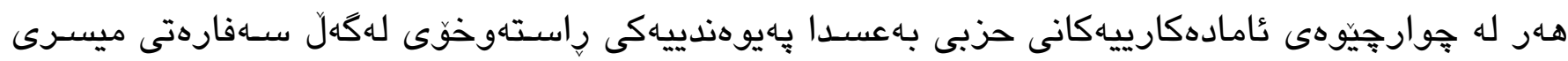
له عيّراقدا هـاهوو، وهك مـهيد فهريدو تهلعهات سـدقىو محهمهد كهبول، كه نامهيهكى له ســلاحهدين بيتارهوه بو حزب هينابوو، هـاهوهها حزب له محهمهد كهبولهوه تهقهمهنىو جههكى ســووك كه له ســورياوه هينترابووه

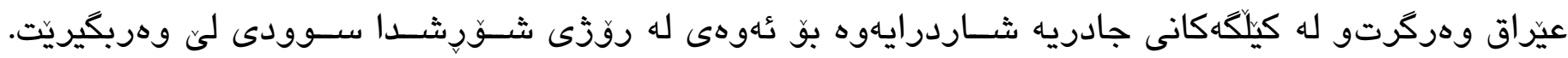

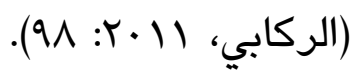

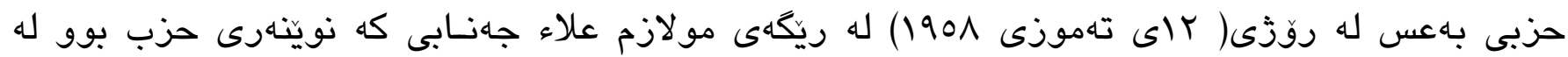

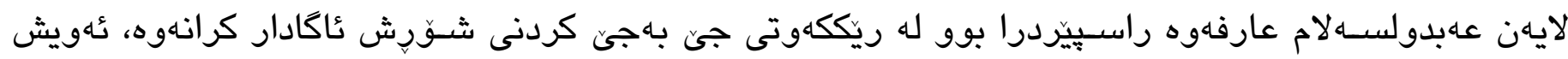

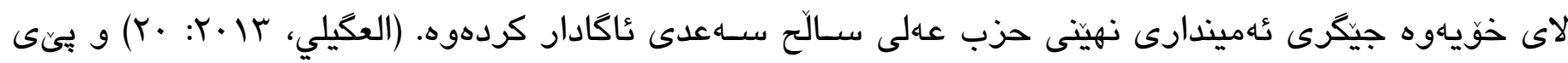

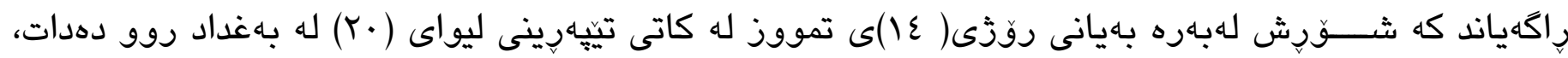

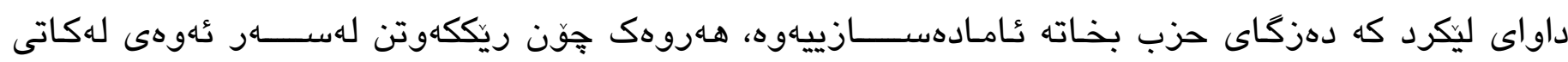

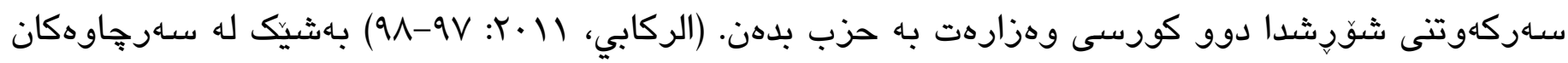

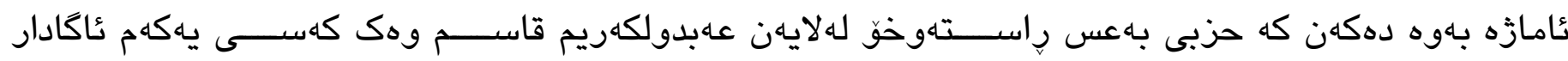
نهكراوهتهوهو ئهمهثيان وهك خالَيكى مـترسيدار ئهزماردووه، كه قاسم جياكارى حزبى بـكارهيناوه له مامـلّه

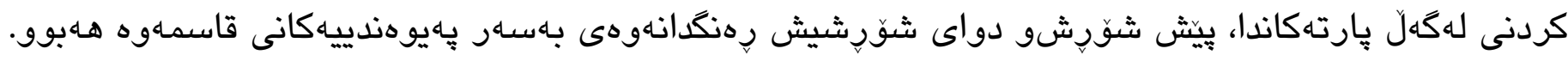

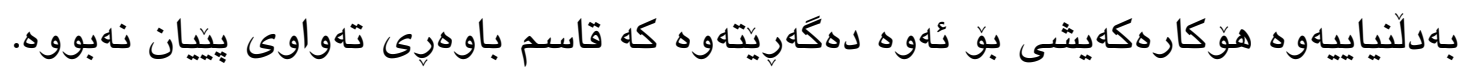

\section{ه-هارتى ديموكراتى كوردبشان:}

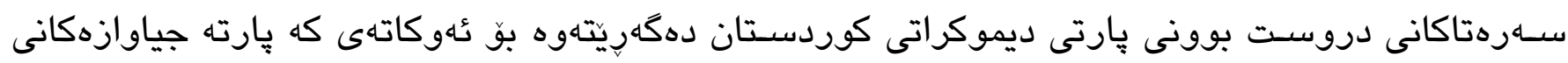

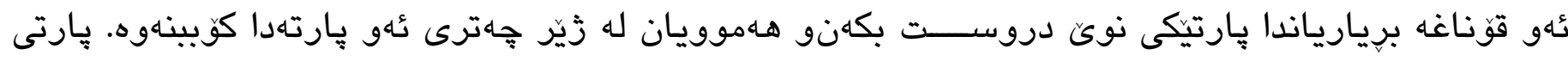

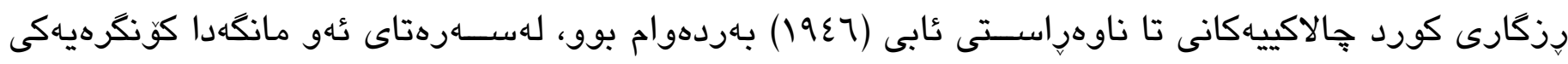

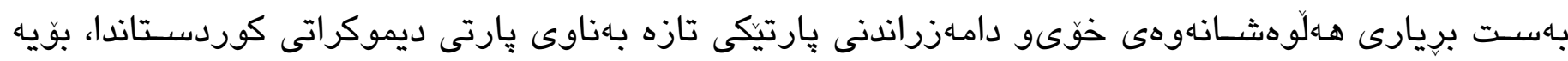

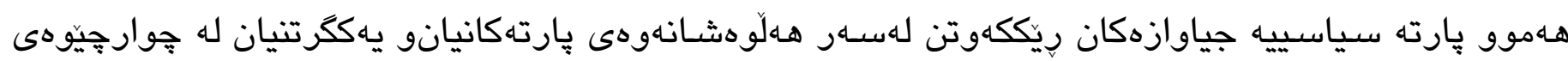

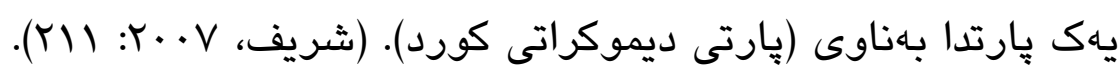
سـاهبارهت به پارتى ديموكراتى كوردستان كه ناوى لهكهل يارتهكانى بهرهى ياكيتى نيشتمانيدا نهاتووه، له

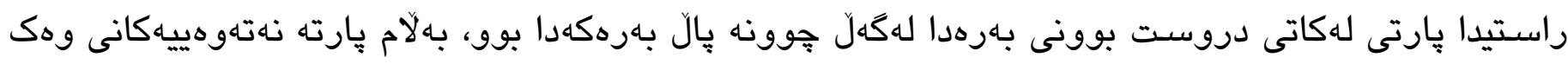

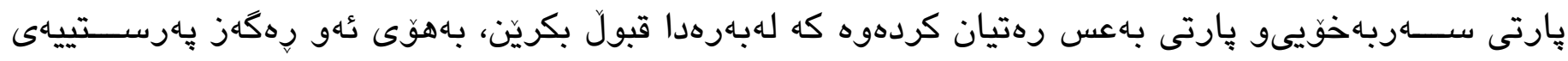




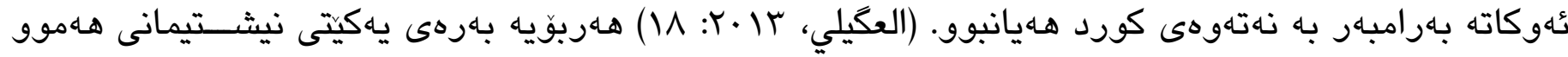

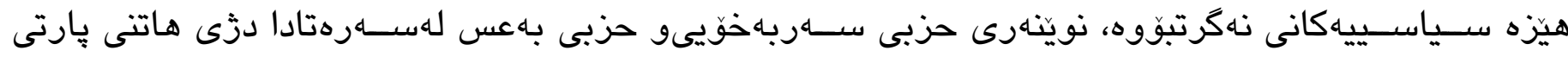

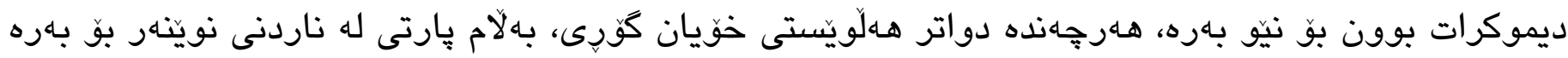

ساردبوّوه. (الزبيدي، (9191: (9V). لهبهرامبهردا پيارتى ديموكراتى كوردسـتان رهخنهى له ثامانج و بـرنامهى بهره كرت، بهوهى ئهو داواكارييه

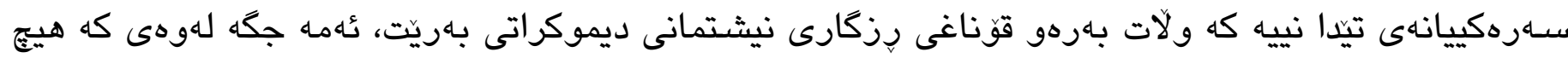

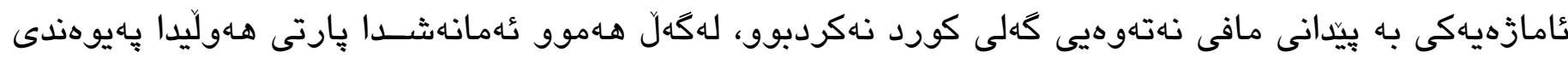

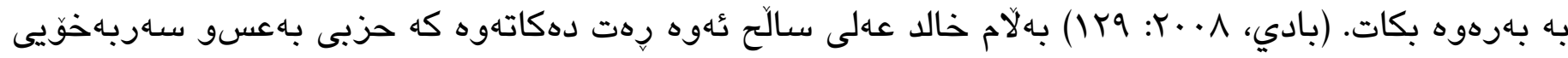

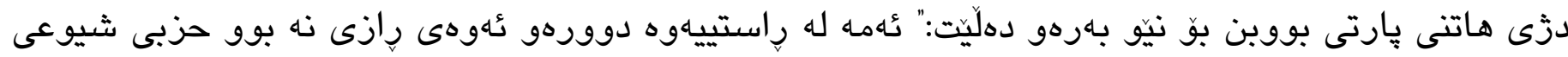

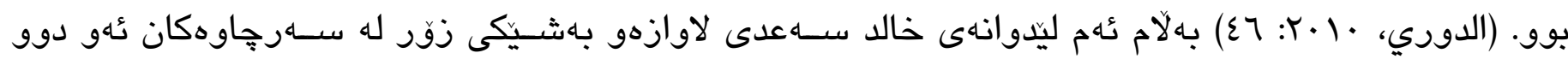

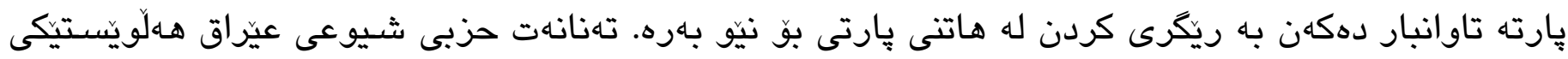

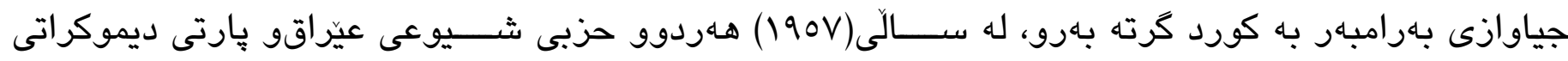

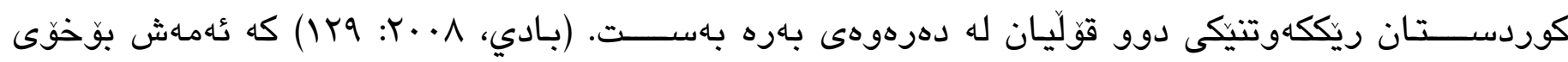

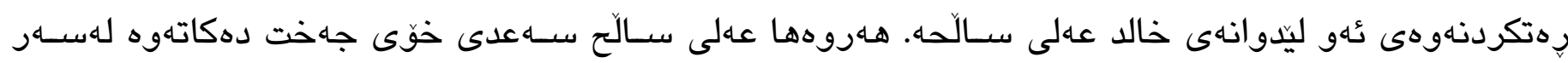

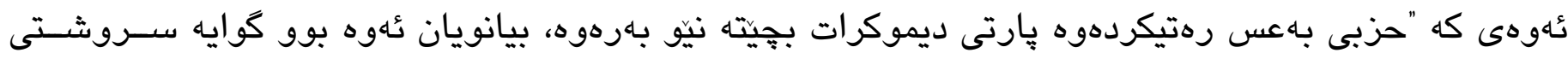

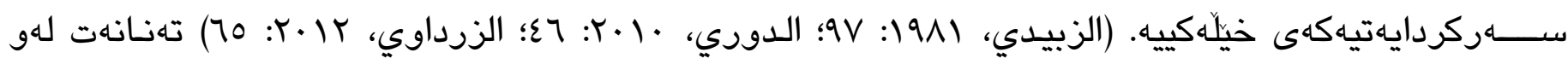

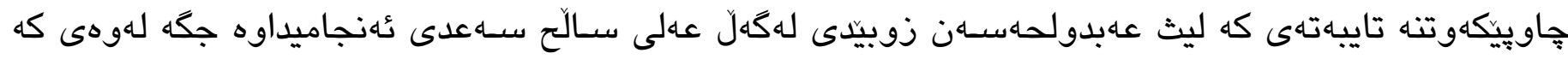

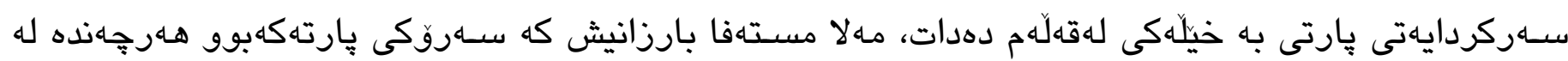

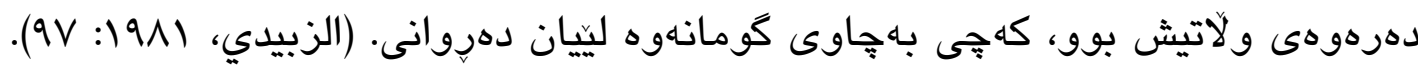

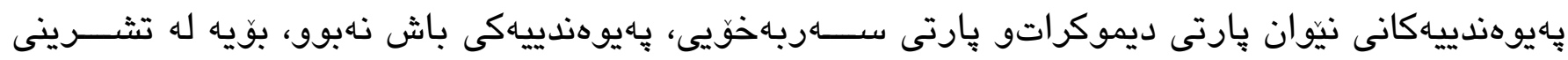

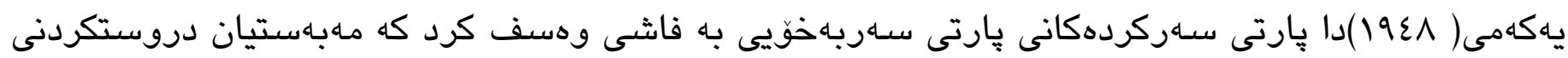

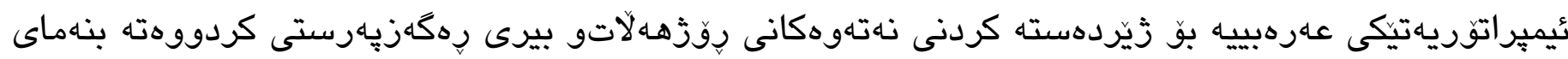

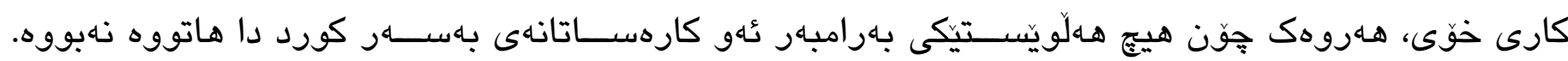

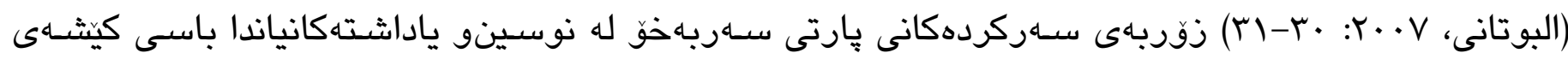

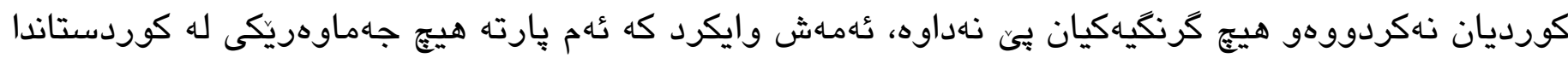

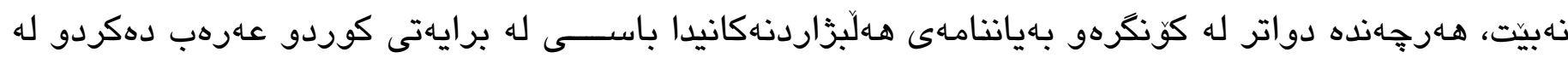

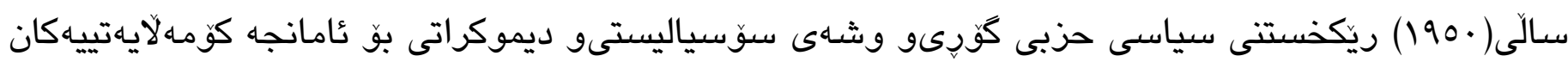

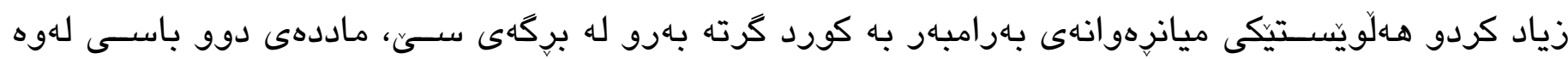
كردووه كه حزب ريزّ له نهتهوهكانى تر دهكريتو هاولّاتيان به عهرهبو كوردهوه لهم نيشـــتماندا هاوبهشــن.

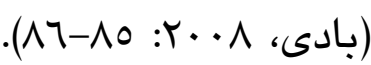




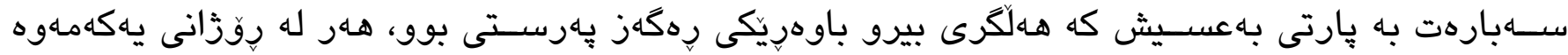

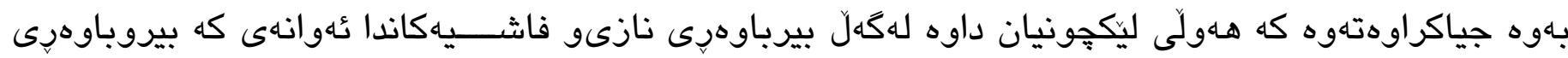

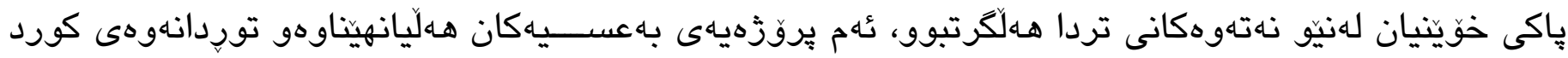

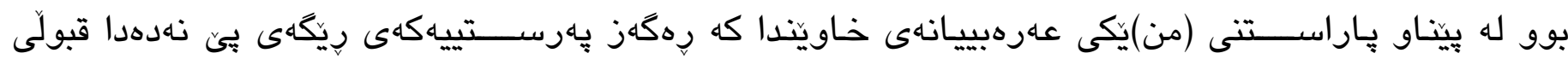

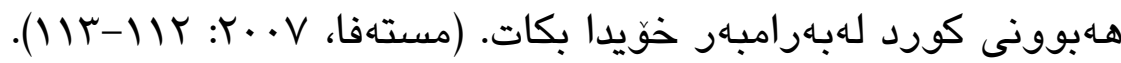

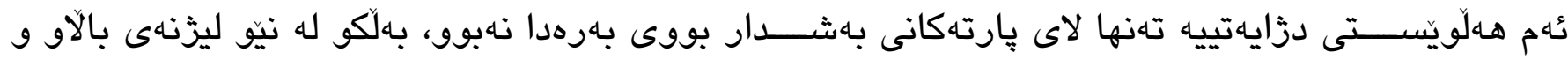

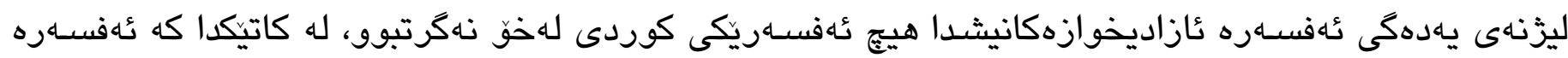

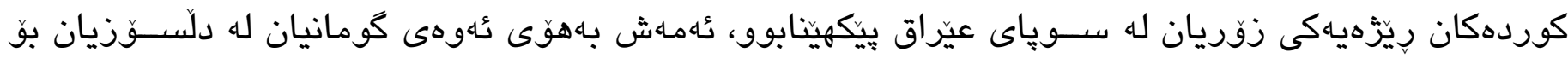

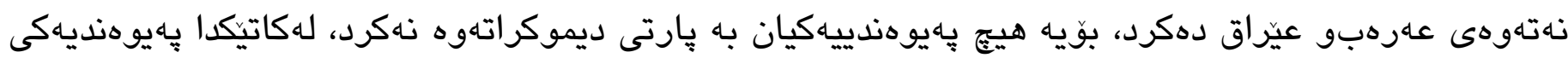

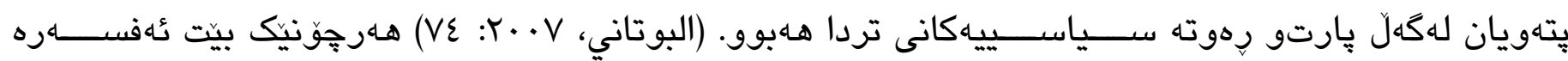

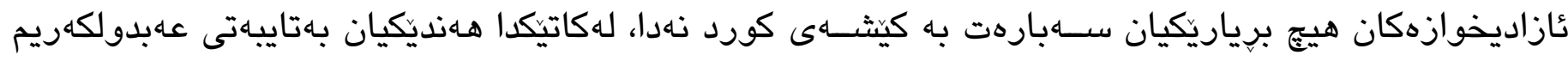
قاسـم بيريان له كيثـاهى كورد كردبووهو لهكَل يّيّانى بهشـيك له مافه نهتهوهييهكانى كورددا بوون. (البوتاني،

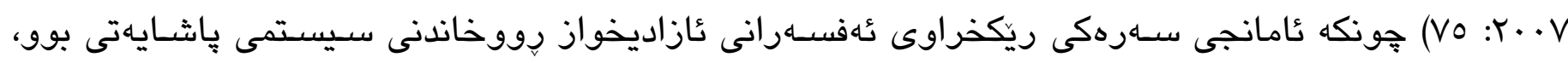

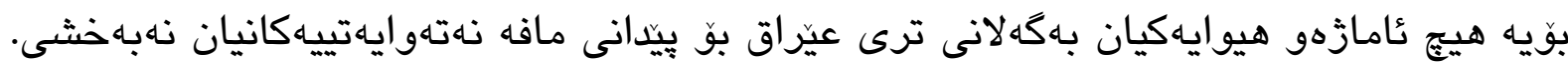

\section{تلهومروى دوومم:}

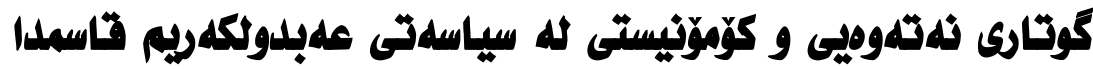

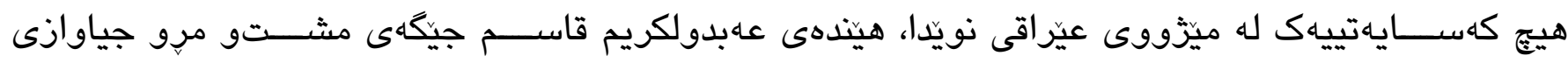

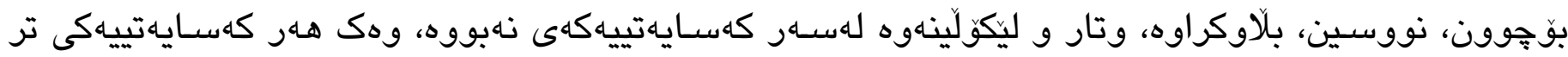

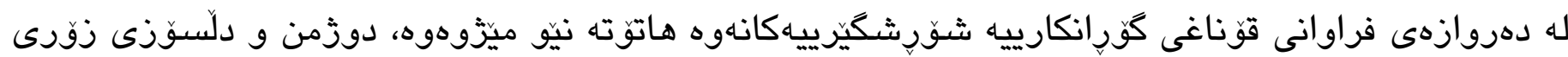
هـهبووه، بوّيه شيّواندن و تومـهتى زوّى تُاراسته كراوه. لهوانه توماهى ليكترازانى نهتهوهو حزبه سياسيهكانو

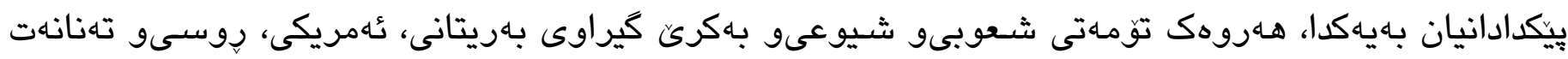

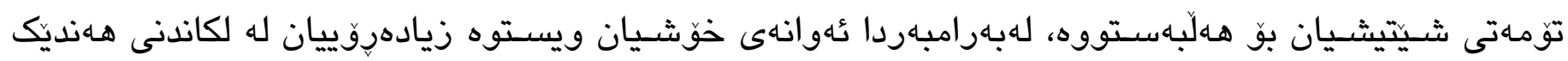

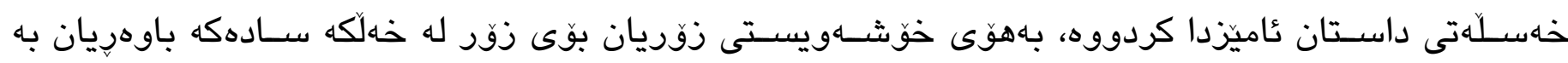

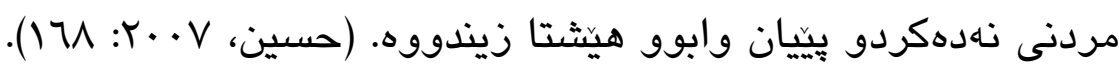

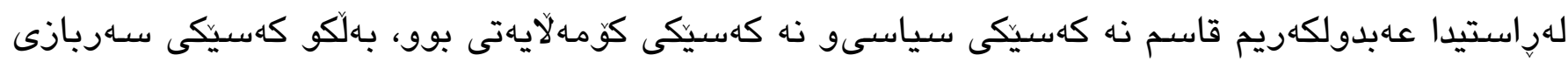

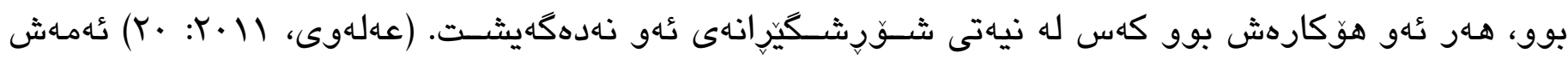

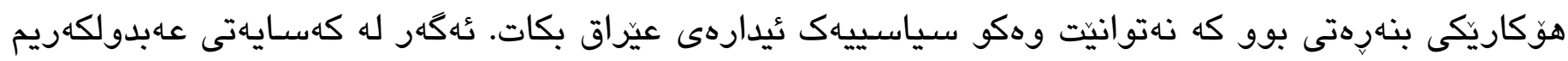

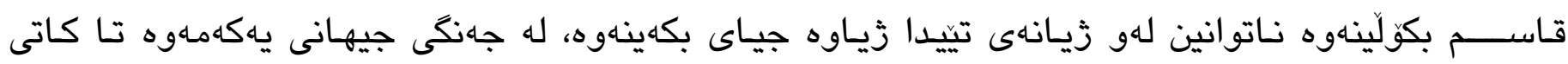




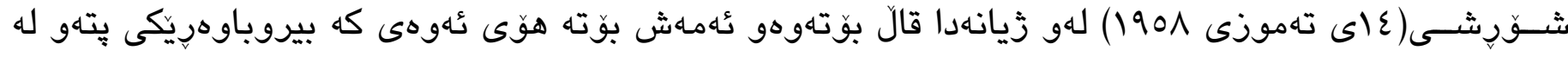

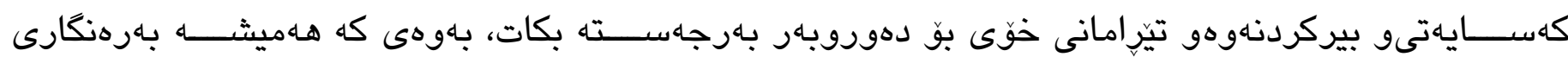

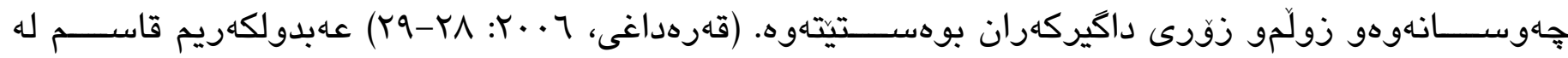

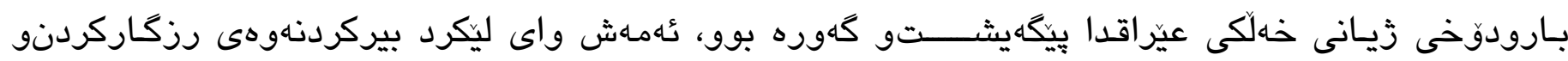

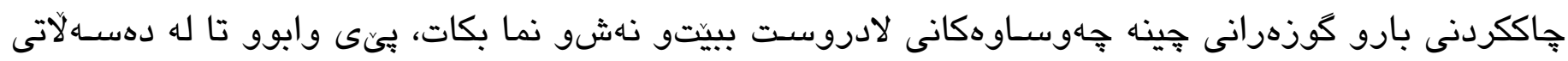

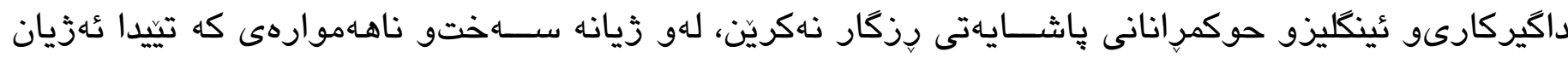

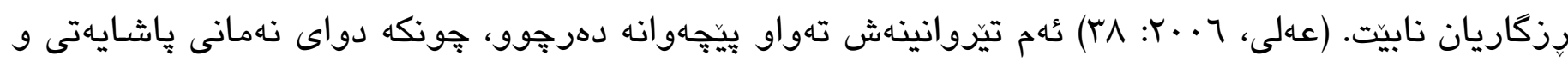

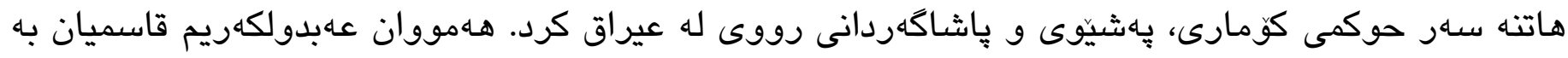

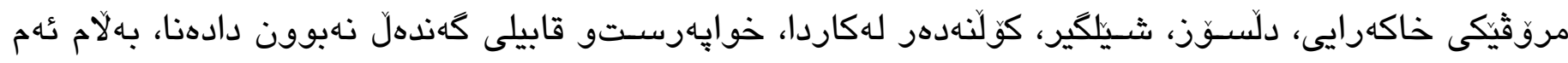

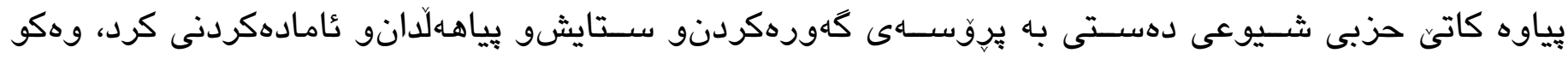

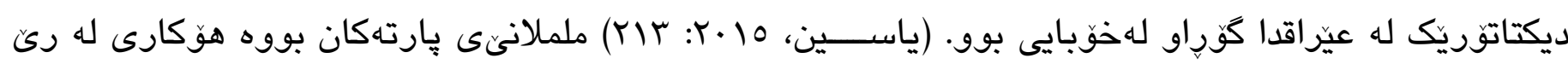

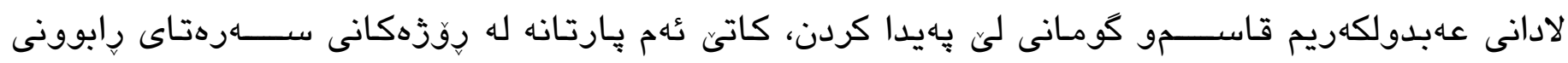

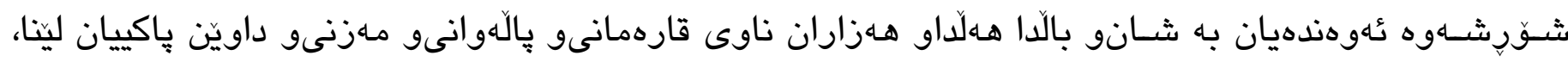

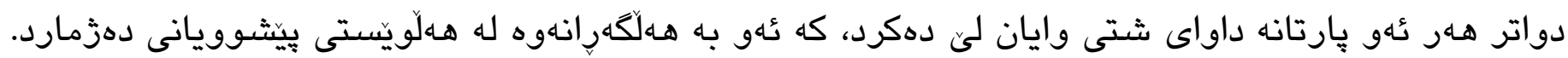
(بارزانى، r) عهبدولكهريم قاسـم تا ئهوكاتهش بيرى للهوه نهدهردهوه بييته سـهركردهى تاكو تهنياو مـزنى ولاّت، بهلاّم

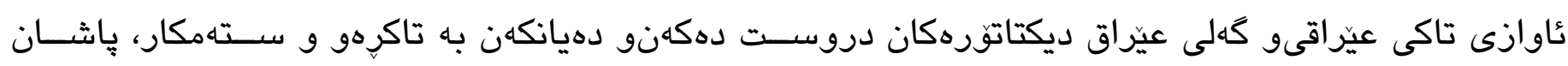

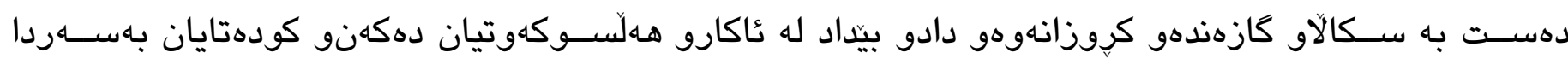
دهكهنو دهيانكوزنو لهناويان دهبهن. (ياسـين، 10 •r: YIT) لهوبارهيهوه عهبدولكهريم قاسـم دواى جوار مانك له بـريابوونى شوّرش له كونكرهى ياريّزهراندا كه له ئوتيل بهغداد بهسترا، دواى ئهوهى لهناوكونكرهكهدا زيّده

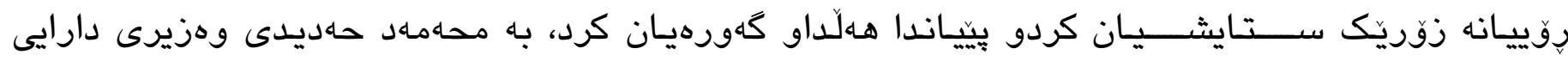

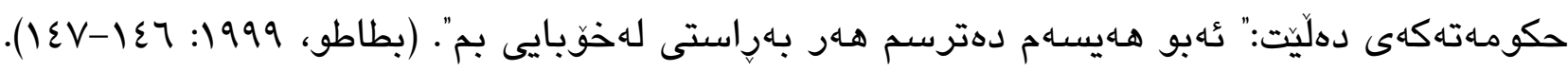

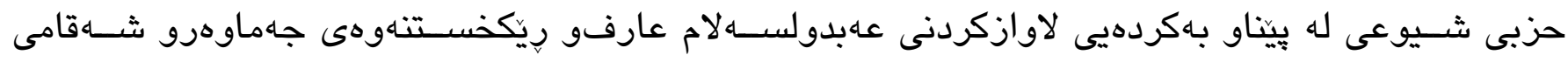

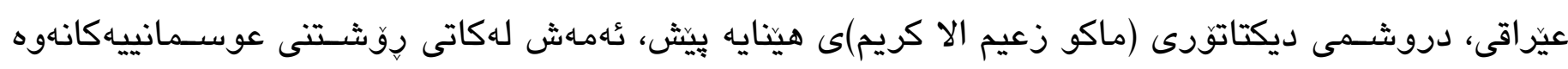

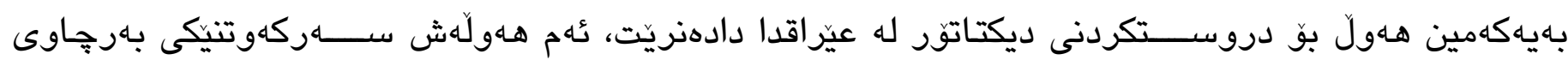

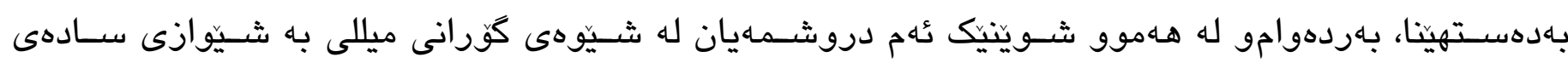

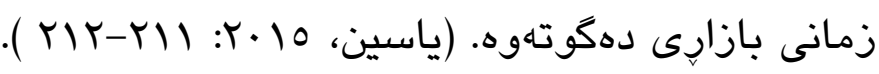

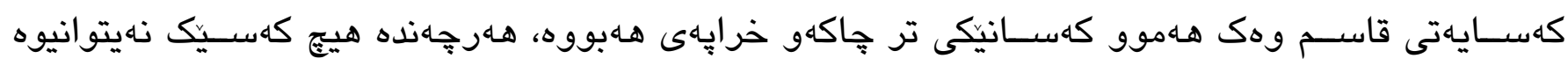

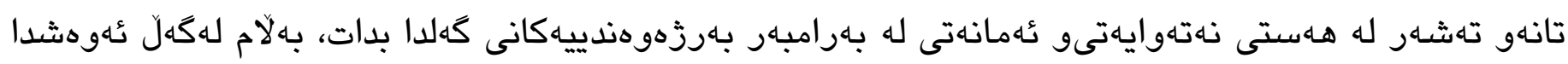

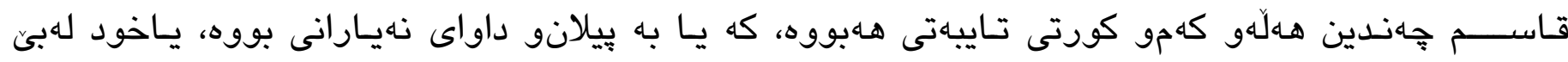




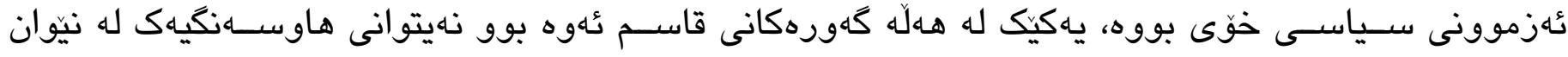

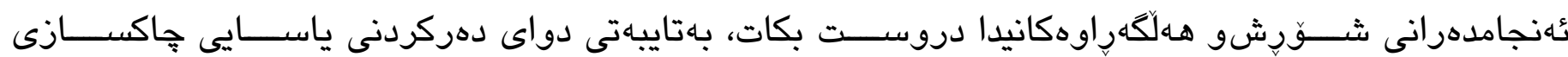

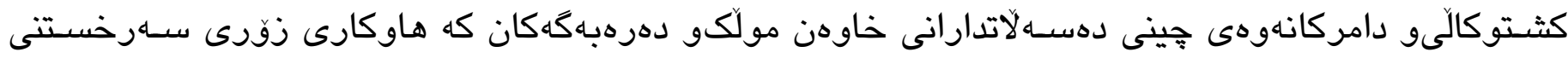

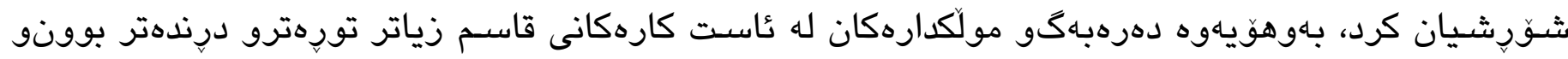

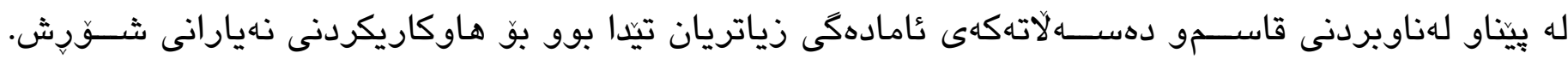

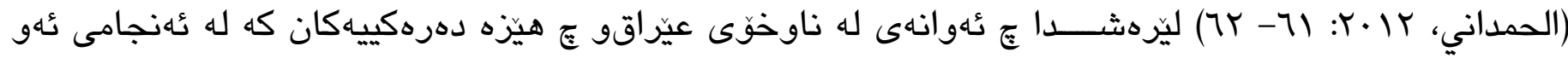

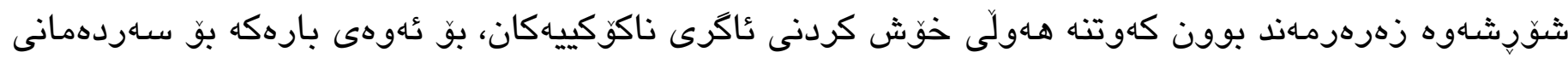

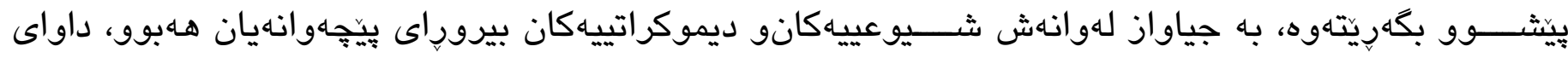

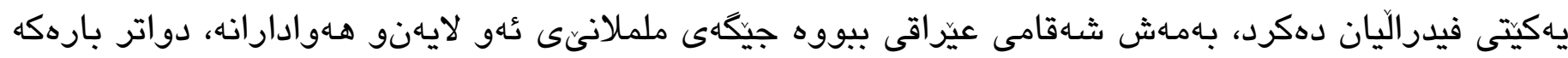

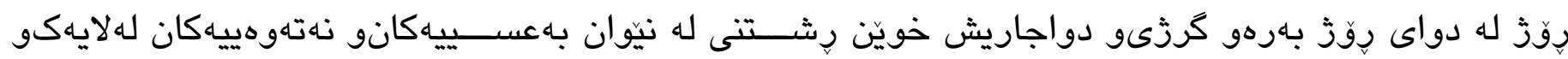

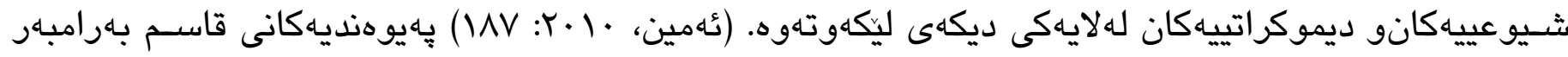

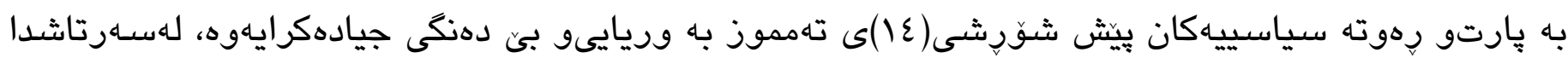

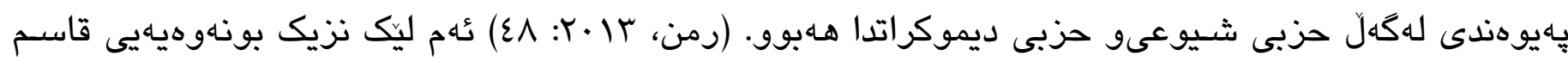
له شيوعييهكان دواتر سهرئيثـاهيهى زورىى بو دروستكرد.

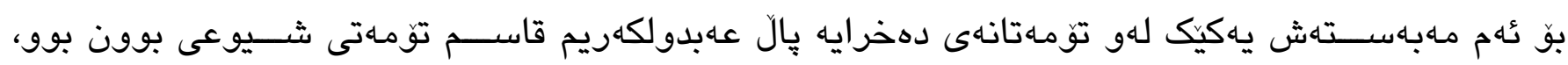

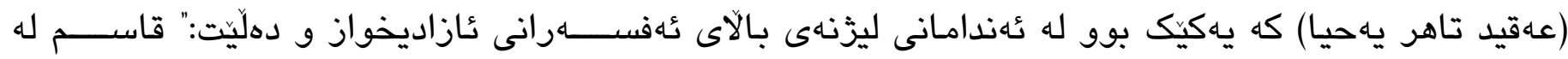

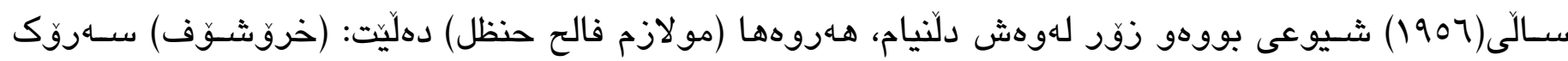

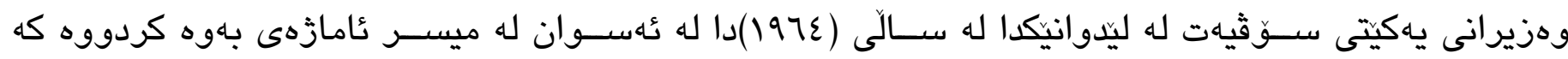

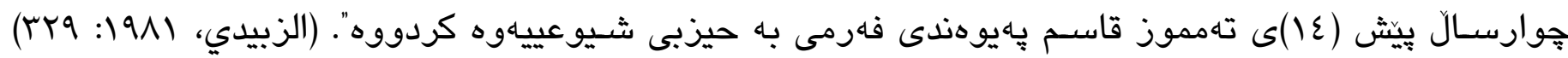

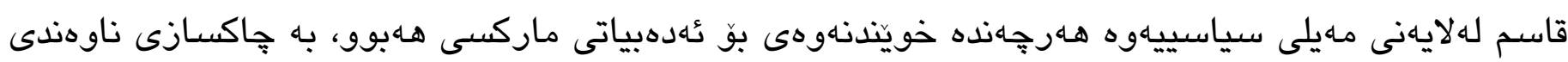
ديموكراتى كاريكَهر بوو، بهلاّم نهماركسى بوو نهديموكراتيش بوو، له سـهرهتاى زيانيدا هـاهليدا له بزوتنهوهى

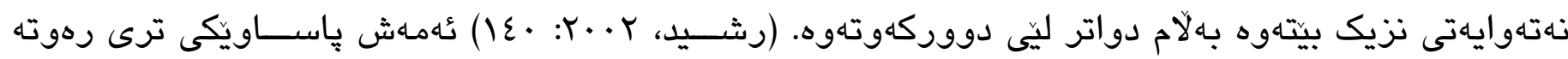
نهتهوهييهكان بوو دز به قاسم.

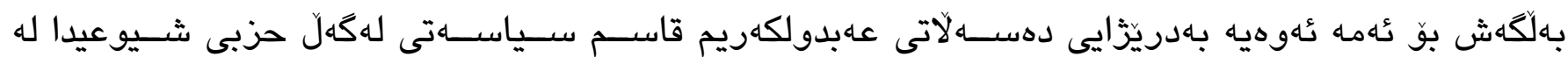

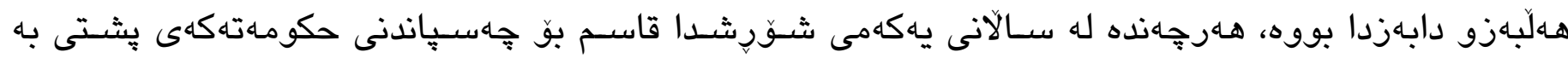
حزبى شــيوعىو ريكخراوه جهماوهرييهكانى وهكو هاويهيمانيتيهك دز به دوزمنو دزه ســياســيـياكانى خوّى بهسـت بوو، بوّيه قاســـ عازادييهكى تهواوى به ريكخراوه ميلليهكاندا كه روكارى حزبى شــيوعى بوون، ثئم

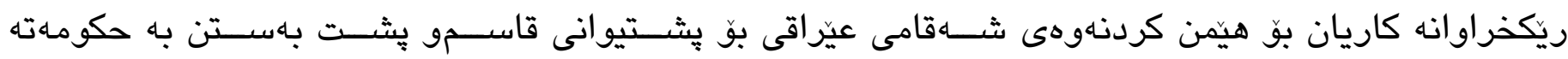

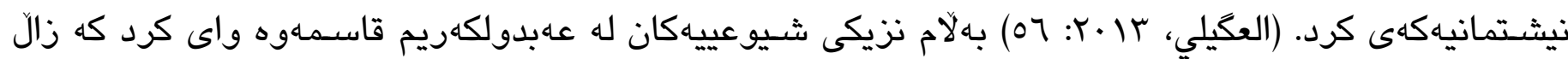

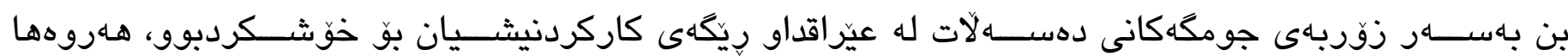




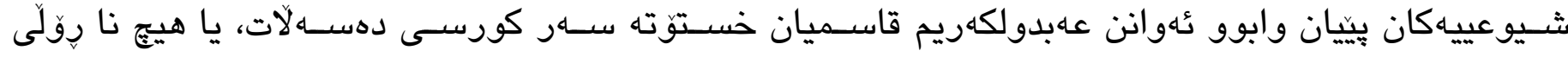

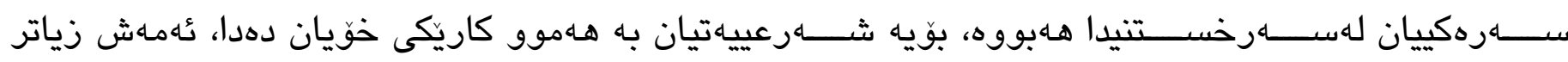

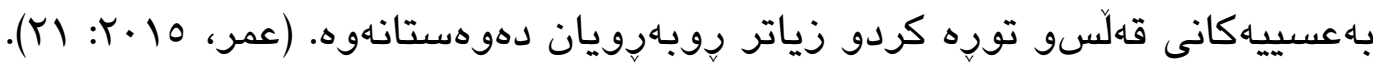

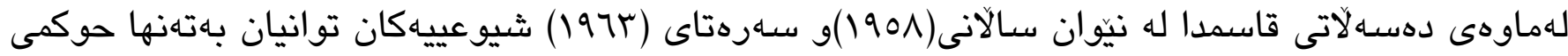

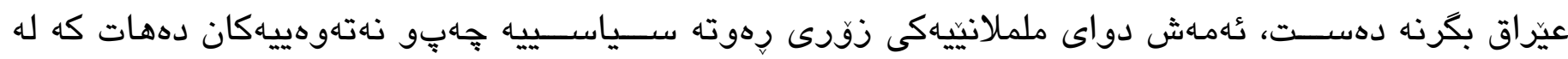

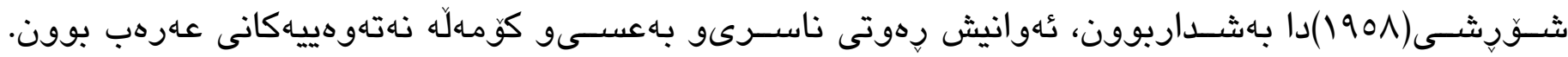

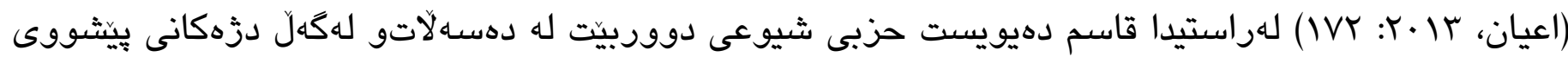

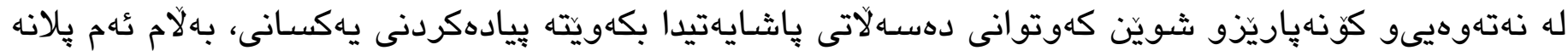

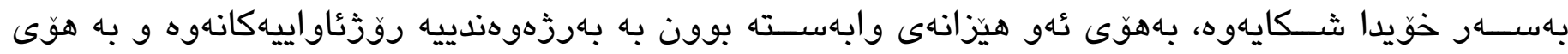

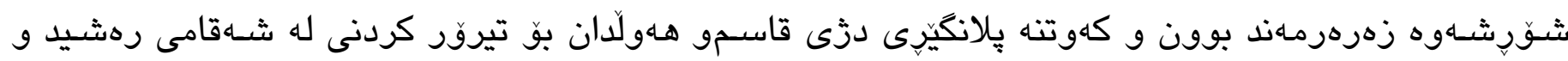

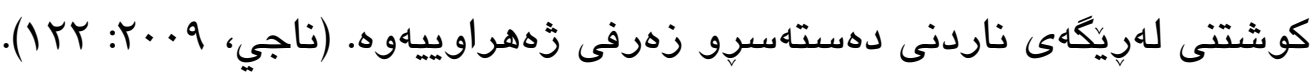

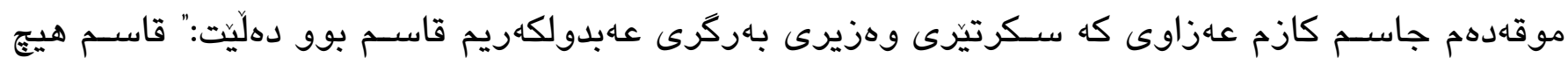

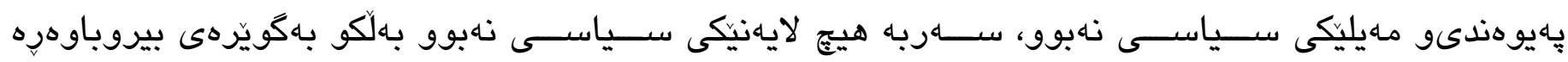

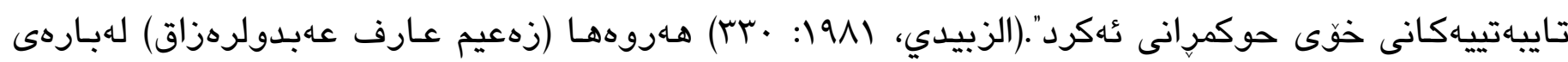

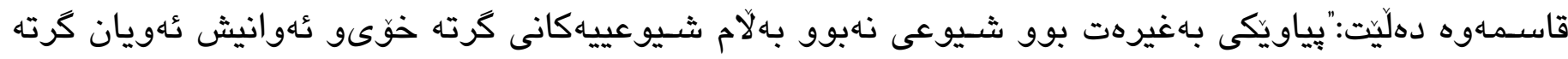

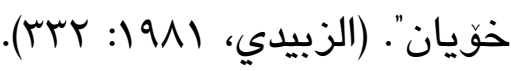

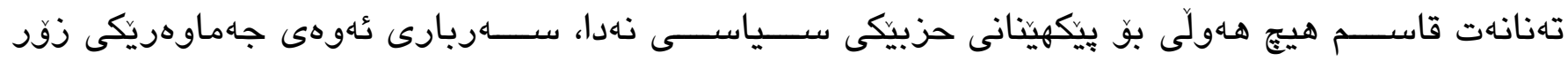

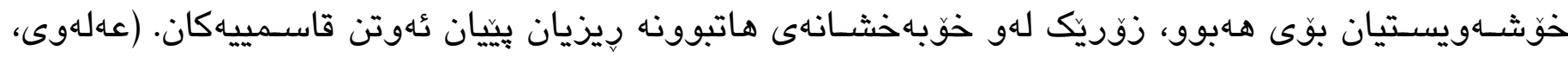

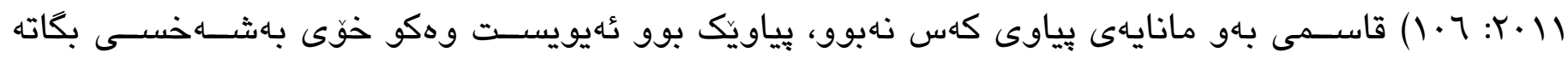

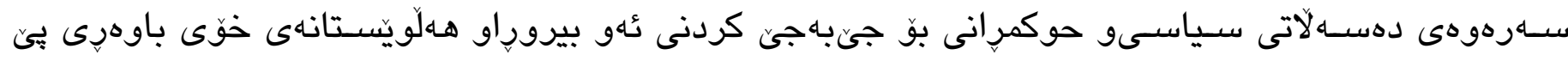

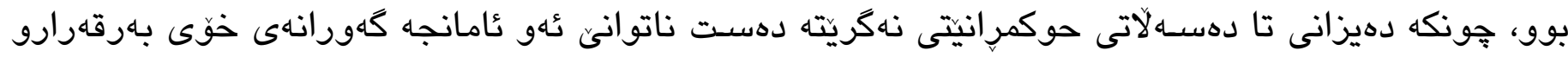

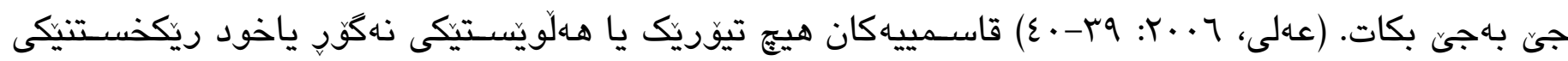

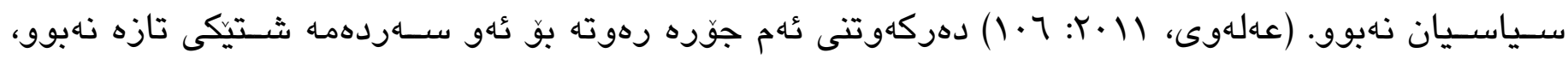

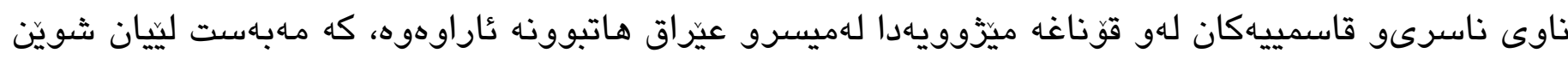
كهوتووانو لايهنكرانى ثٔهو كهسيايهتييه سـياسـيانه بوو، وهك ريكخسـتى سياسى بوونيان نهبوو. لهمبارهياهوه

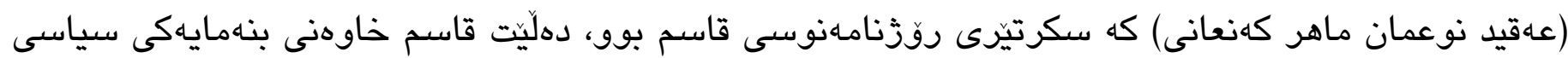

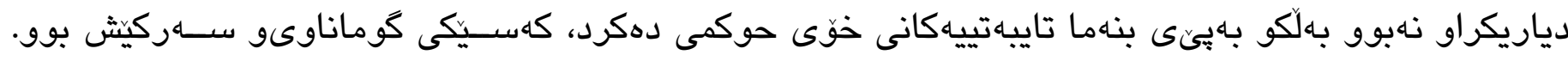

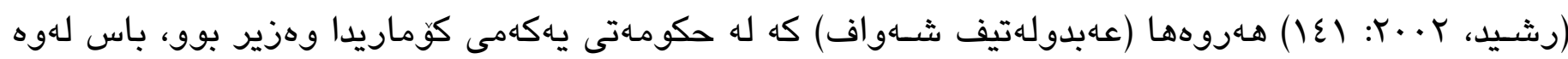
دهكات كه ئيسماعيل عارف داواى له عهبدولكهيم قاسـم كردووه حزبيكّى تايبهت بهخوّى دروسـت بكات تا ئهو

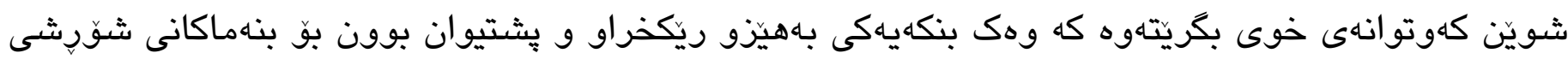




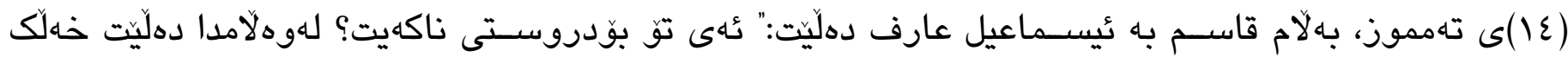
دواى من نهكهوتوون دواى تو كهوتوون". (شبر، V. •.r: (Y).

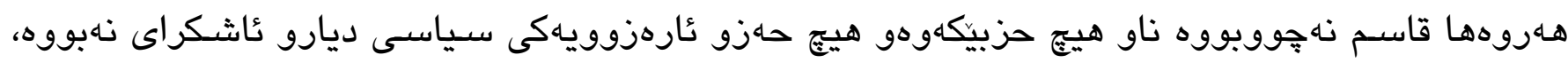

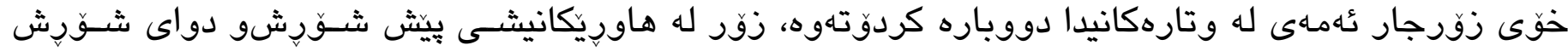

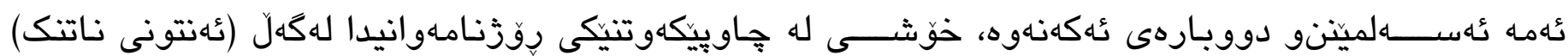
وهزيرى بهريتانى يِيثــوودا دهلّيت:" من هـهوو كات لهكَهل هـهوو كَلم من هـهوو كات له ســـرووى مـيلهو

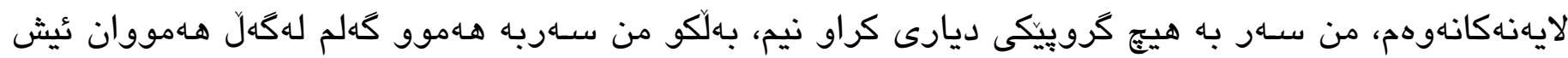

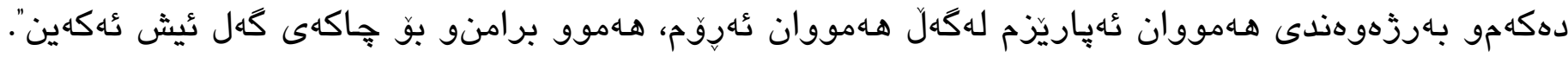

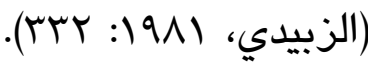

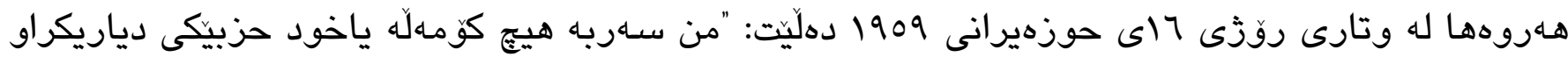

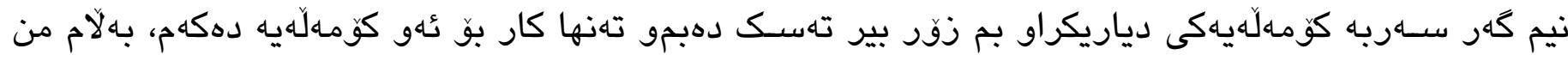

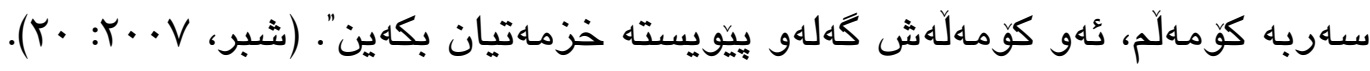

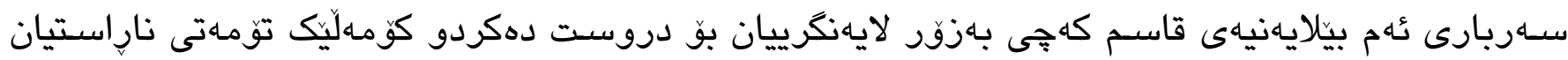

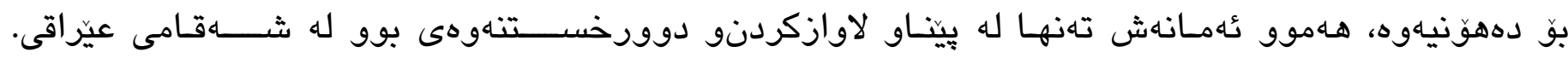
باهسـييهكان ياكيك بوون لهو لايهنانهى بـردهوام قاسـميان به شـيوعى ياخود لايهنكرى شـيوعييهكان تاوانبار

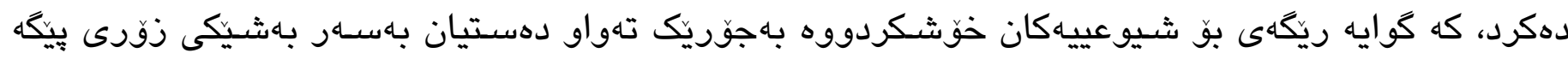

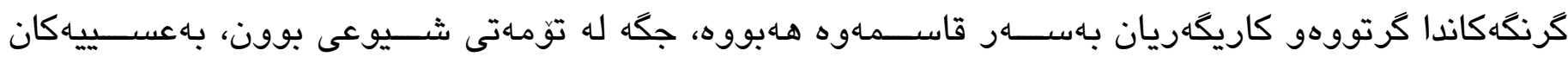

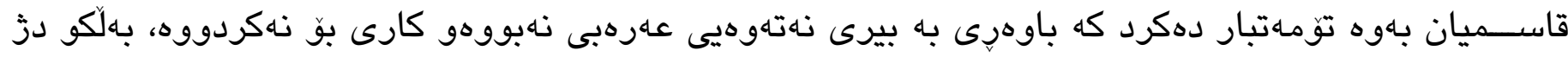

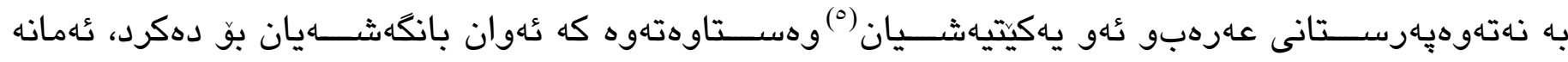

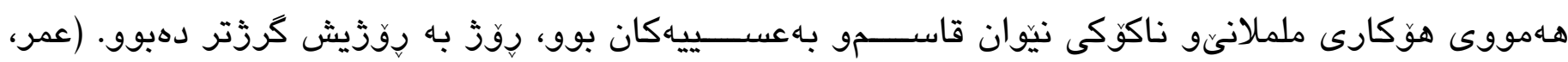
.$(Y \cdot 10$ له بارهى ياكيتى عـرهبييهوه، قاســـم هـميشــهـ جهختى لهوه دهكردهوه كه يهكيتى عهرهب، كُهلانى عهرهبى

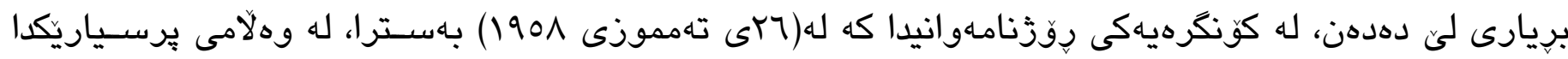

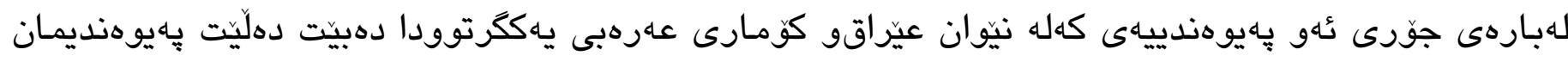

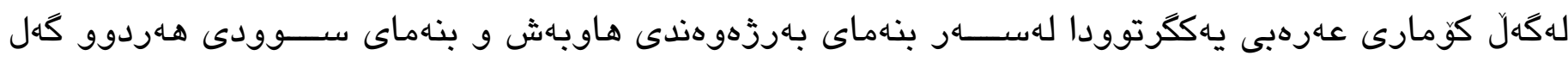
دهييّت، حهزدهكه جهخت لهوه بكهمهوه كه ئهم نيشـتيمانه لهنيّوان عـرهبو كورددا هاوبهشـه. لهم رسـتهيهوه

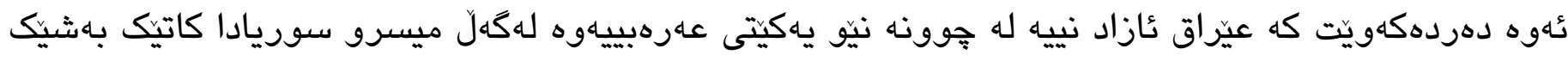

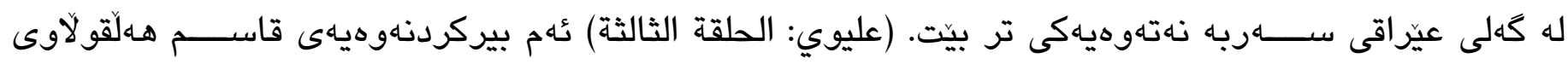

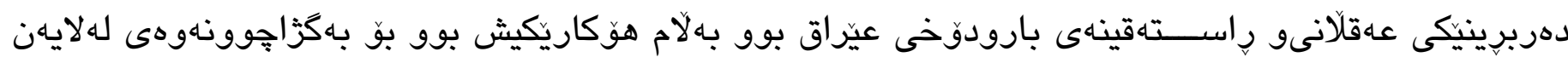

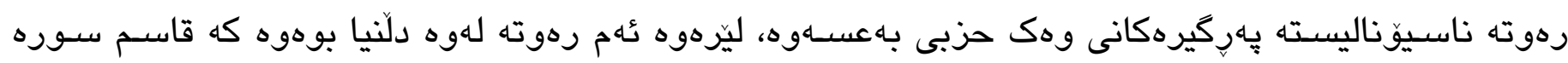




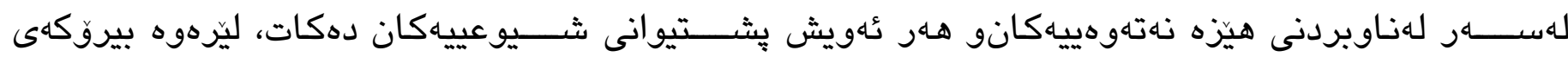

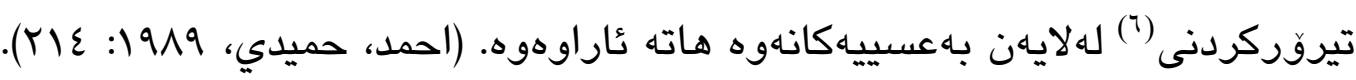

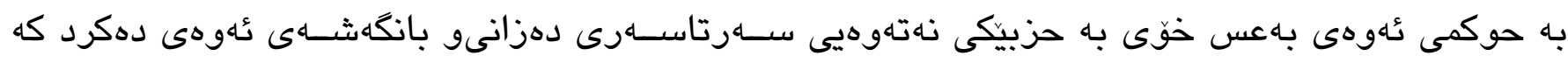

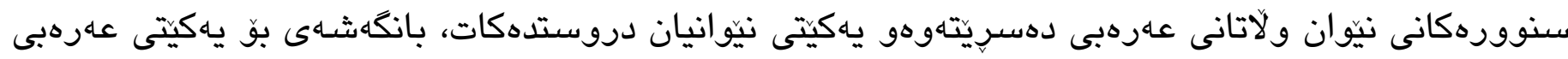
دهكرد، لهبهرامبهريشــدا عهبدولكهريم قاسـميان وهك كهــايهتييهكى ديموكراتخواز نمايش دهكرد كه دز بهو

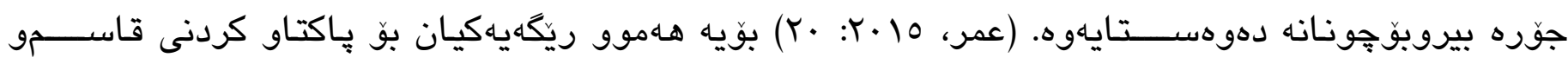
لايهنكرانى كرتهبهر. (نوعمان ماهر كهنعانى) دهلّيت: "قاسـم له سـهرهتاوه رقيى له نهتهوهى عهرهب بوو، تهنانهات

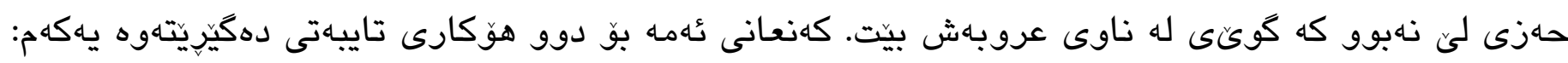

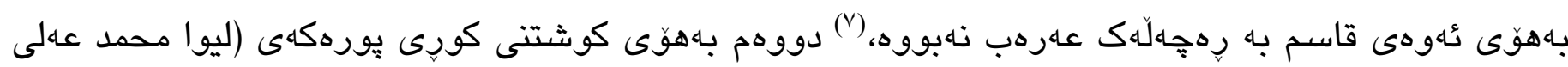

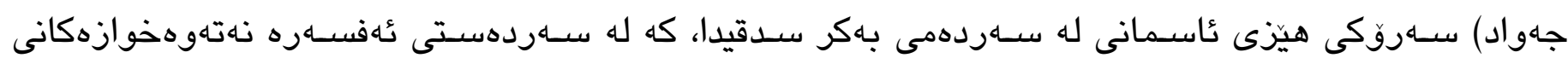

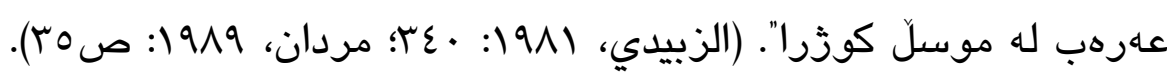

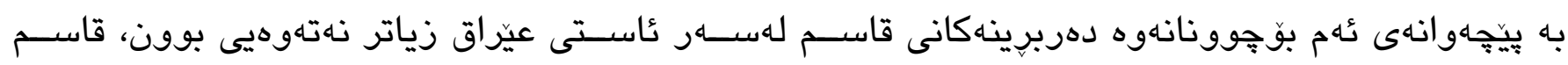

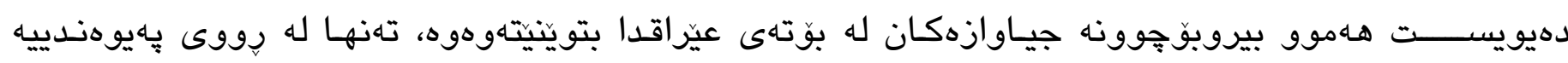

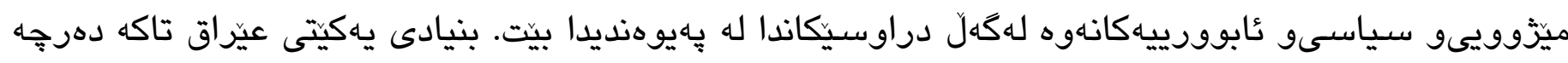

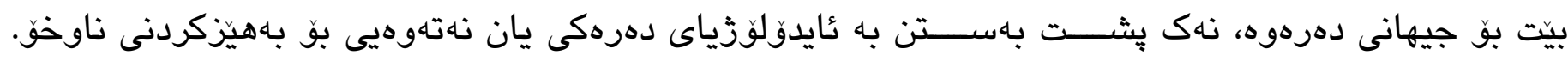

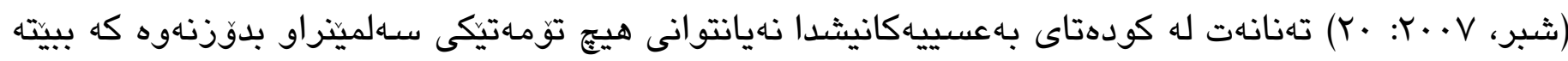

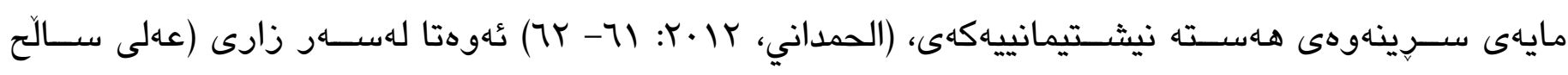

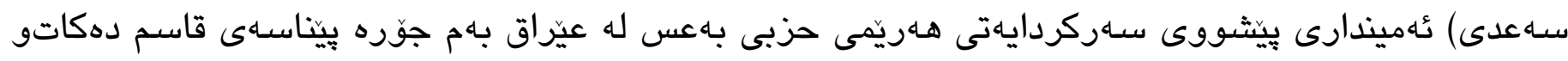

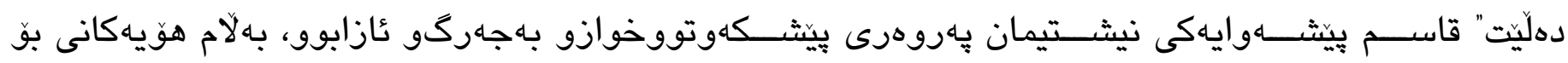

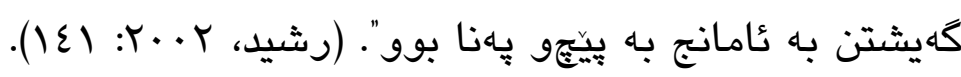

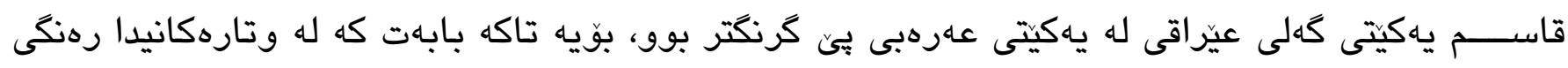

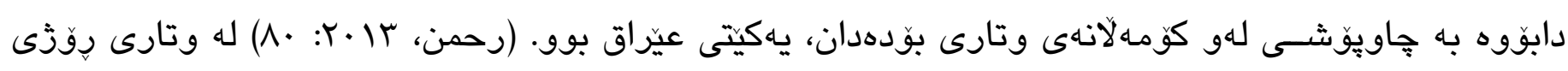

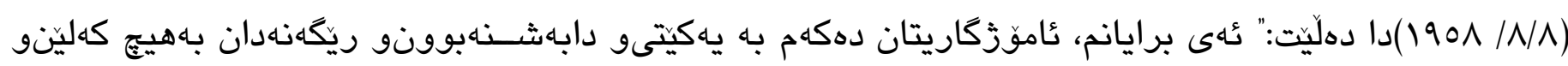

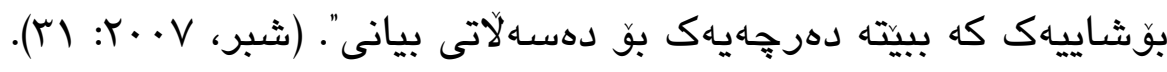

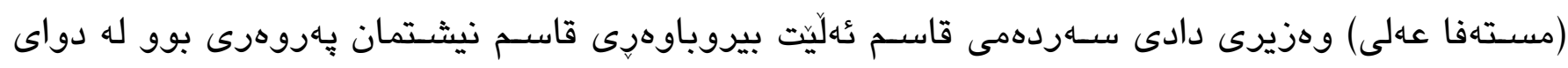

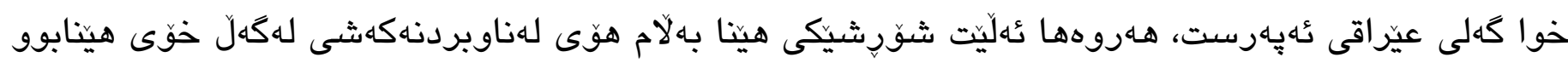

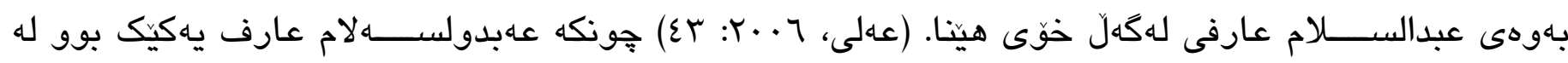
عهرهبه نهتهوهييهكان، ململانييهكى زوّر له نيّوانياندا بوو.

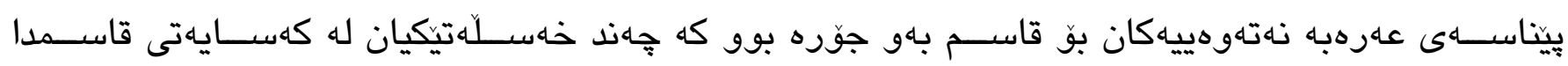

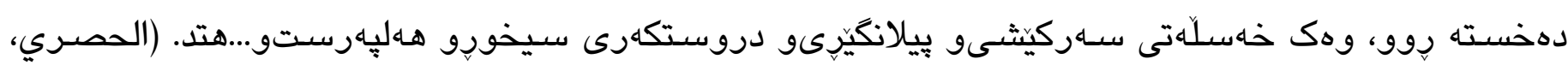




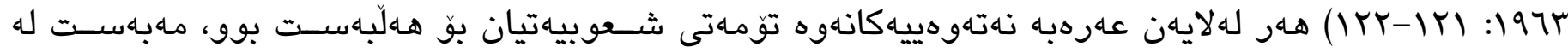

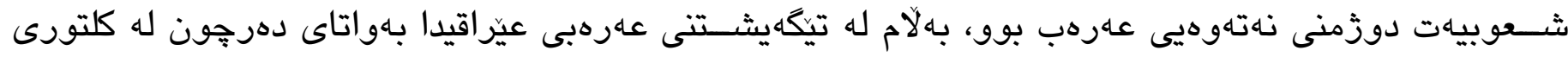

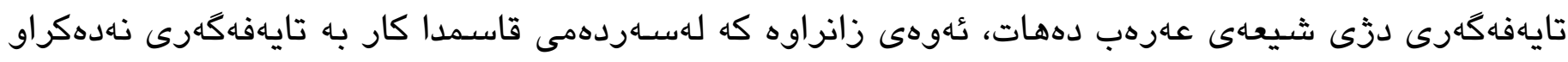

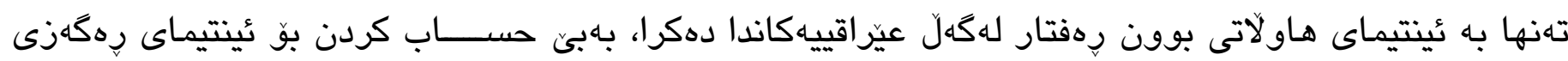

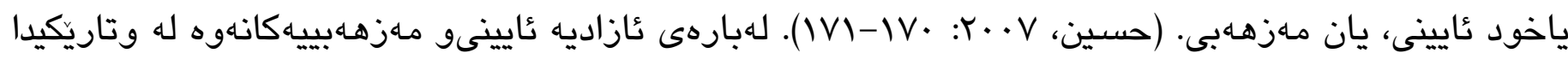

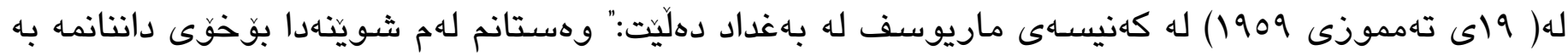

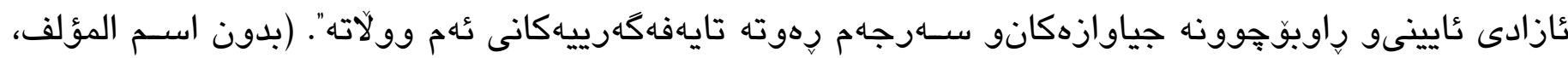
.(£广: 197 .

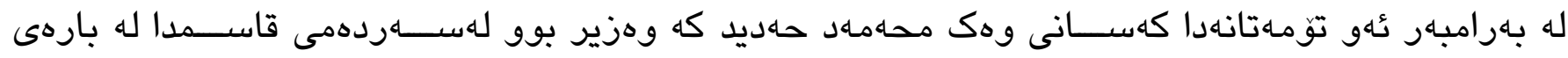

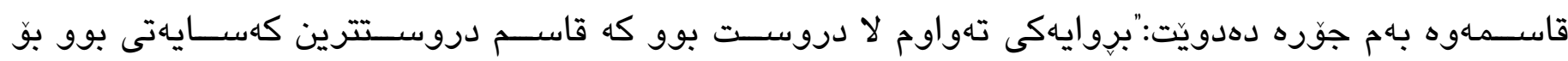

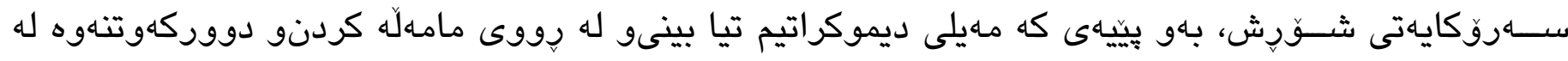

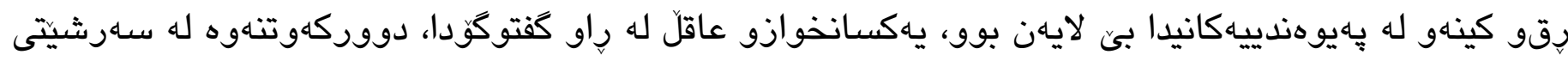
له قسـاهو هـلوّيستهكانيدا. بههوَى كاركردنم لهكَلَ قاسمدا سـربارى نارهزاييم لهو شيّوازهى كه دهيكرته بهر له

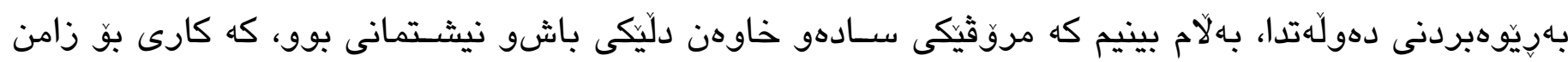

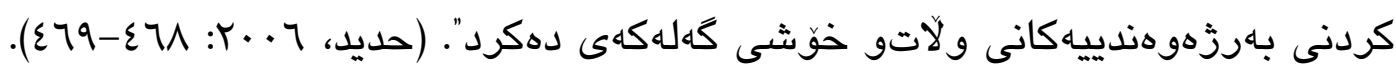
دوزمنانى قاسـم هـر بهوهوه نهوهستان بهلكو تومـهى شيّت بوونيشيان بوّ دروست كردو له نوسينهكانياندا

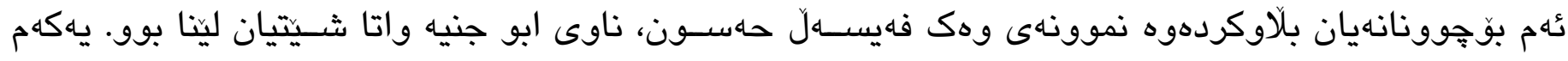

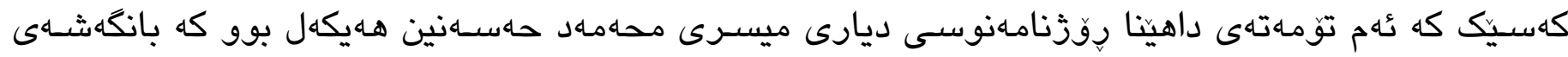

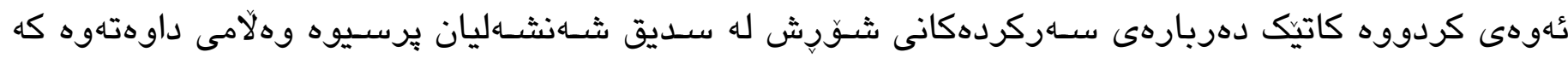

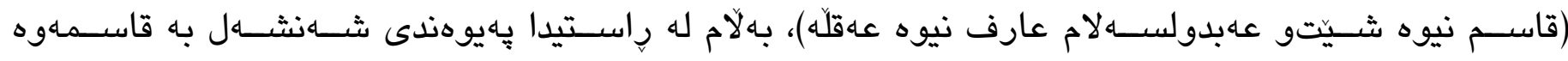

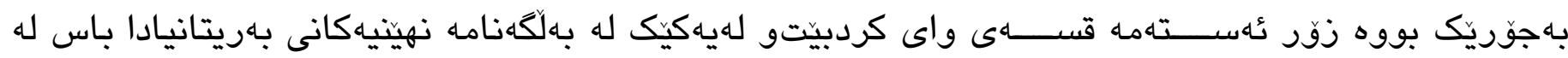

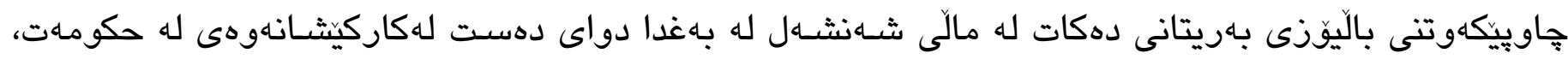

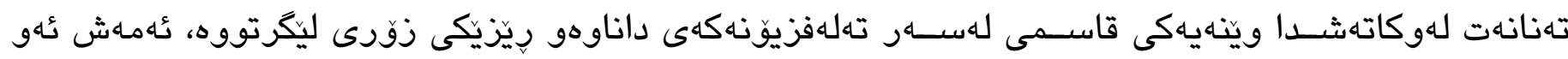

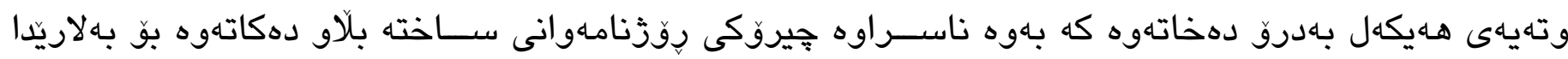

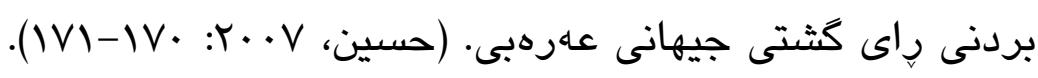

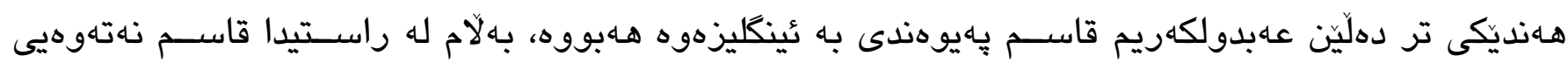

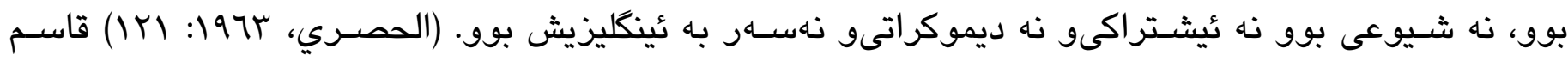

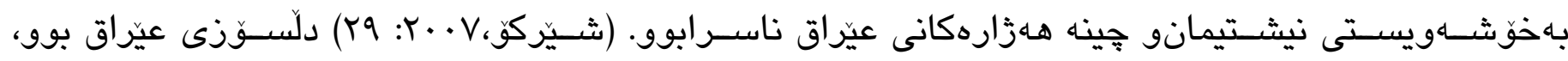

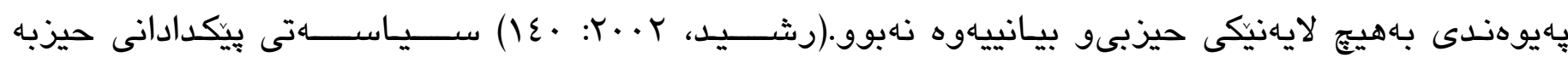

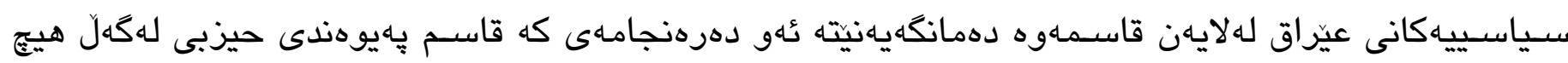




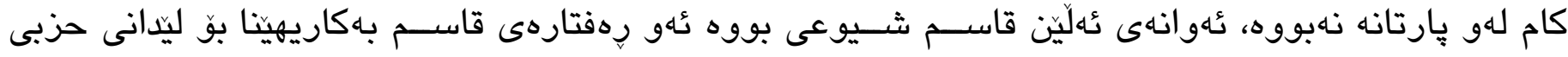

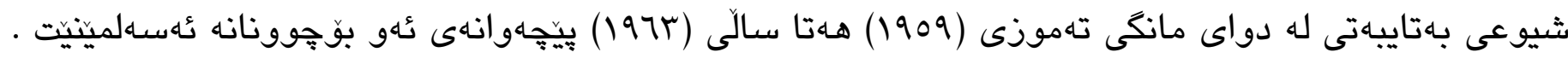

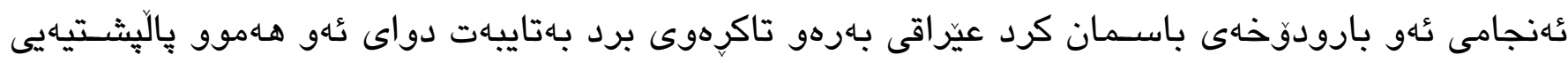

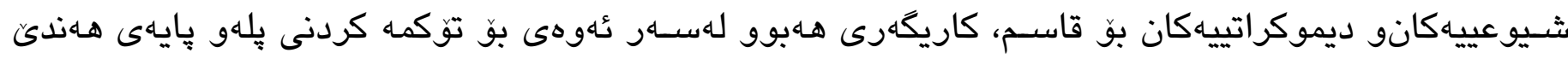
هـانكاو باويّت، يـكيك لهو هـهنكاوانه لادانى عـبدولسـهلام عارف له يوّستهكهى بوو، دواجاريش دورخستنهوهى

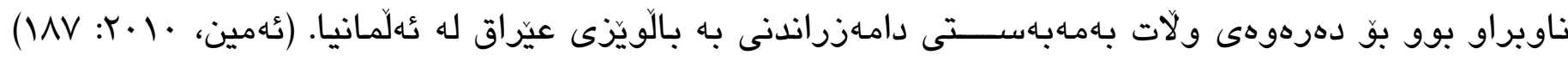

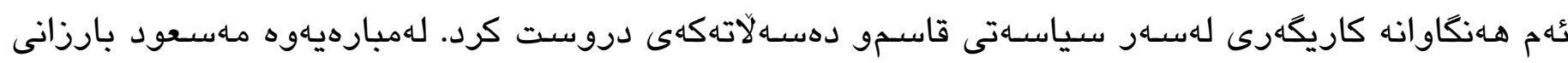

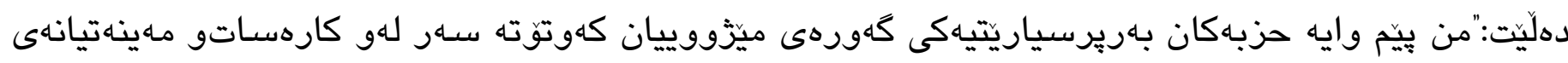

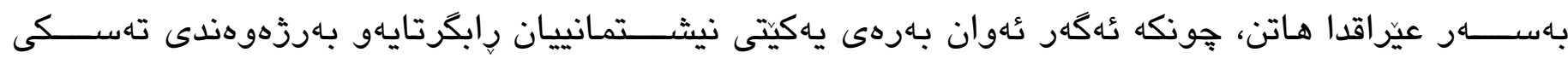

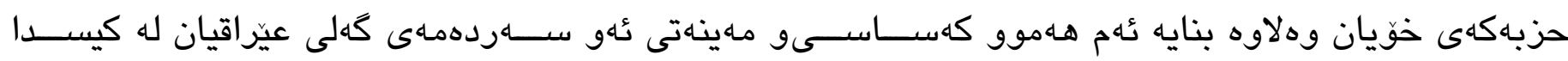

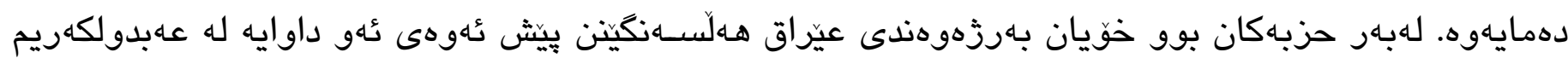

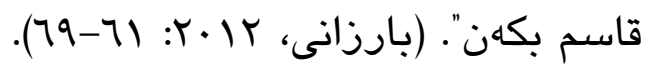

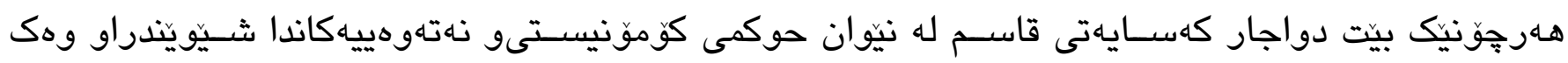

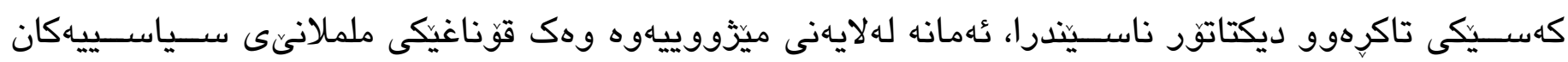

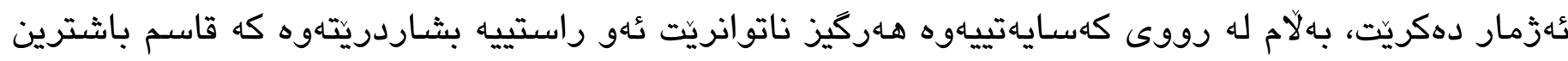

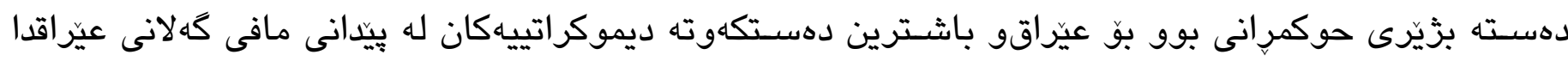

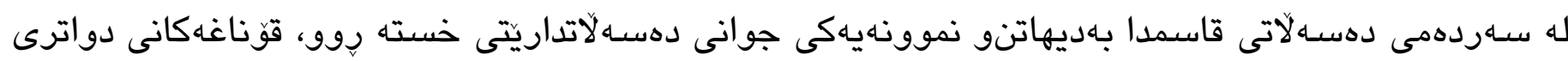

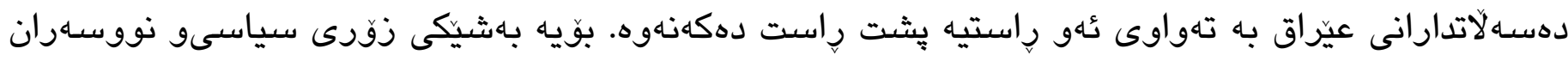

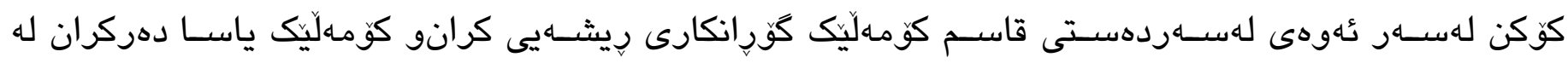

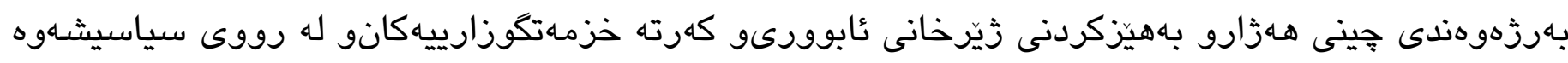

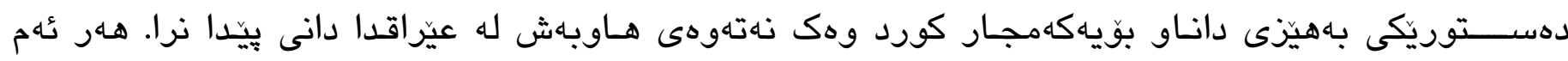
دهستكهوتانهش كهاياهتى قاسم له يادهوهرى تاكى عيّراقيدا دهيلّيتهوه. 


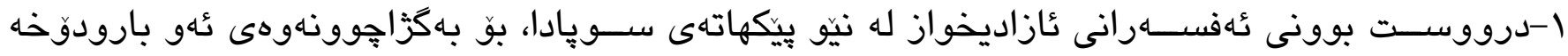

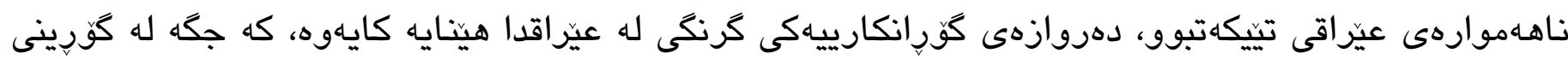

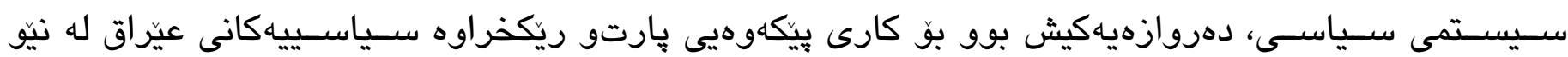

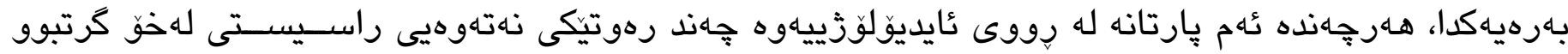

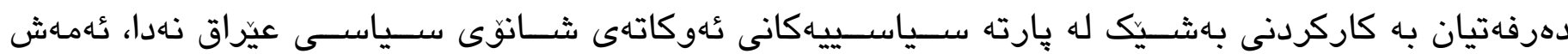

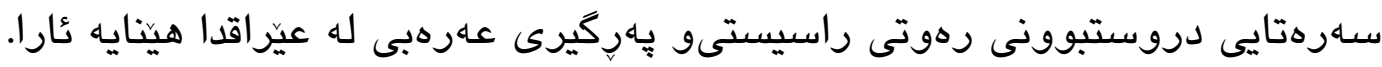

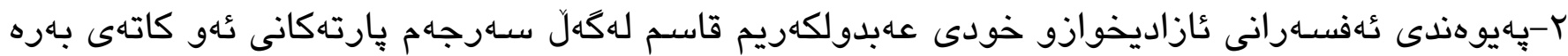

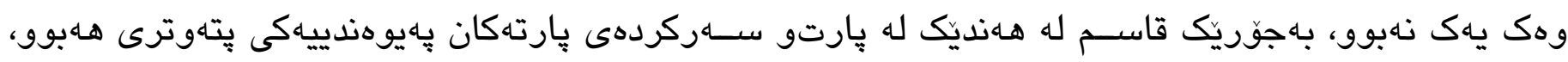

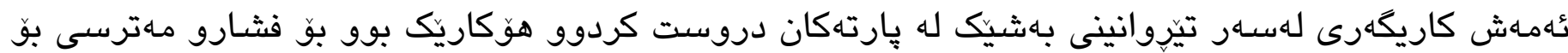
دهسـلاتيى قاسم دواى شوّرش.

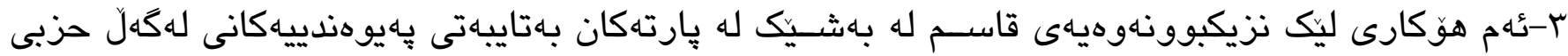

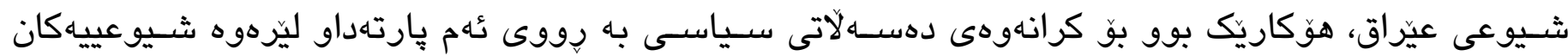

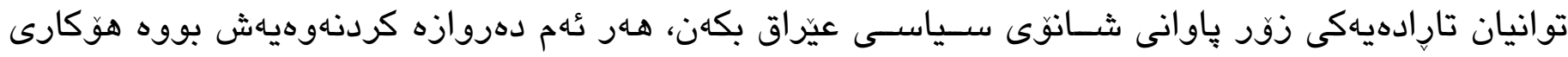

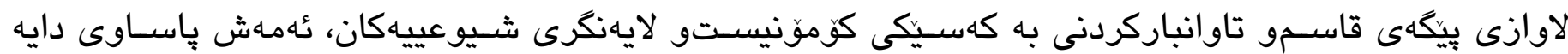

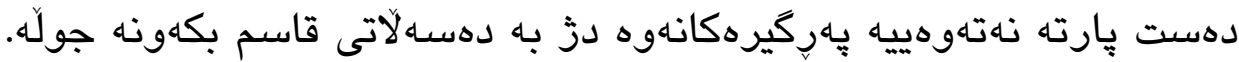

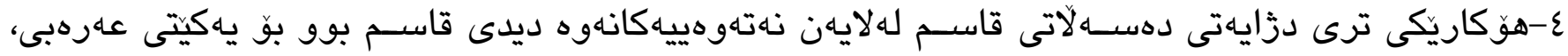

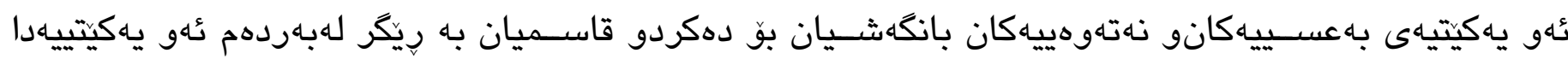

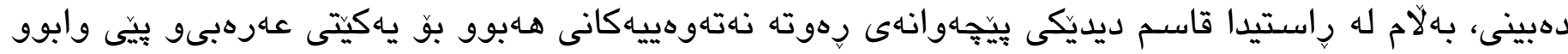

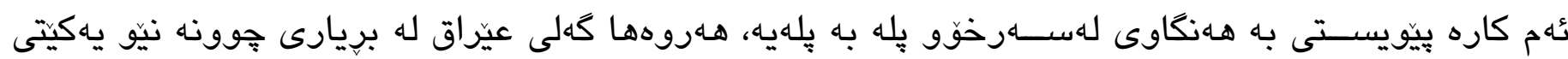

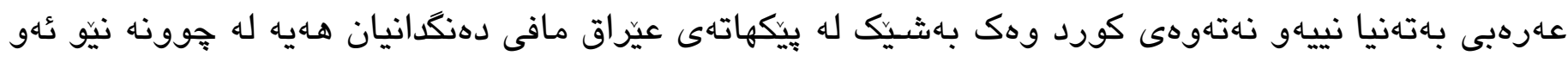

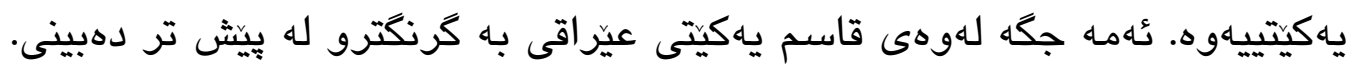

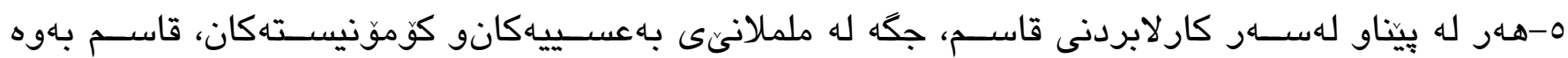

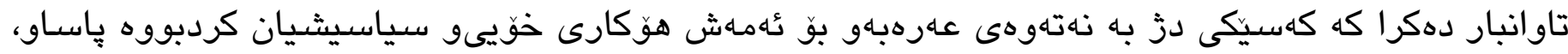

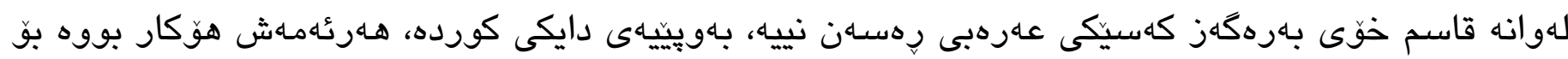

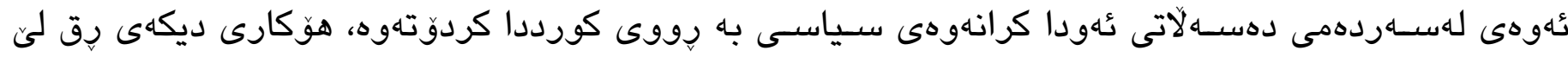

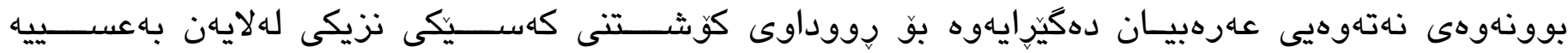

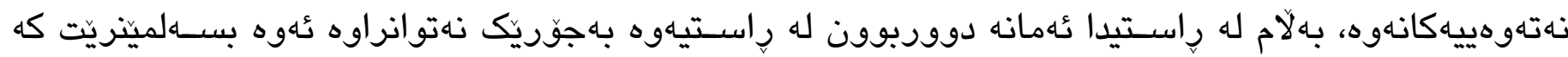
قاسم كهيكيكى دز به نهتهوه بووه دامالراو بووه له هـهتى نهتهوايهتى. 


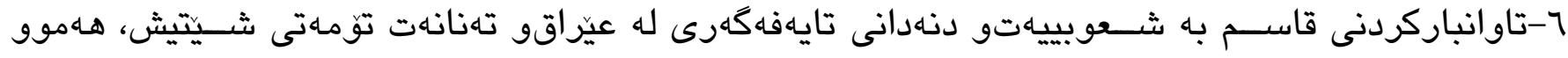

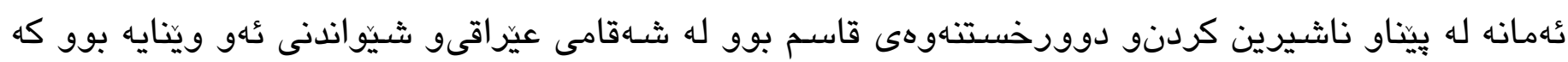
ماوهيهكى زور بوو كاريان له كَهردكردنى دهكرد، به جوريّك نازناوى (ماكو زعيم، الا كريم) بيووه هوتافى

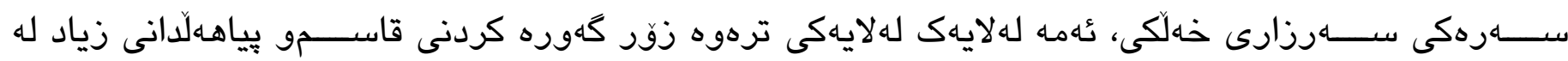

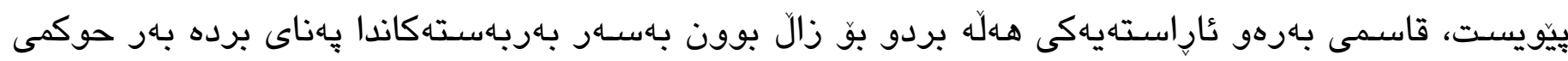

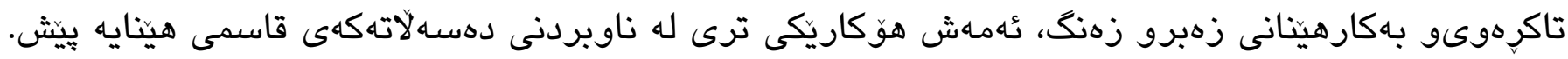

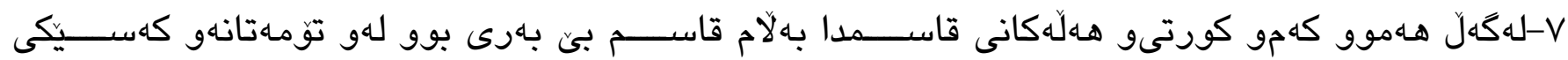

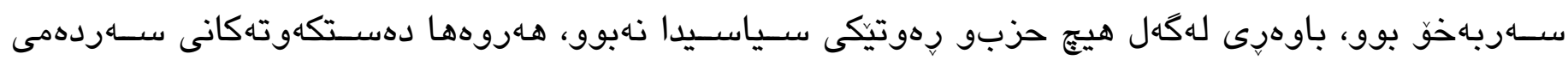
قاسميش دهرخهرى ثَهو راستيهن كه باشترين دهستهزيّرى حوكمرانى بوو له عيّراقدا له كوَنهوه تا ئيستا. 


\title{
The Character of Abdulkarim Qasim is Between National and Communist Discourse
}

\author{
Suzan Karim Mustafa \\ Department of History, College of Humanities, University of Sulaimani, Sulaimani, Kurdistan \\ Region, Iraq. \\ E-mail: Suzan.mustafa@univsul.edu.iq
}

\begin{abstract}
:
In the revolutions of history, an individual or leader is always given a higher role than all perpetrators of events, leaders have always been recognized as heroes in history, and a leader has faced all the factors of success and failure. In all societies, one or more people have always appeared and dominated the entire political and economic spheres of the country, a factor in the self-perception of history, or the hegemony of history, while the achievements of history belong only to one or the first leader, the total number of participants in the process of changing roles and his Impact on the direction of events.

Abdul Karim Qasim is an example of a leader in Iraq who went from revolution to dictatorship, while people looked at him with hope and described him as a leader who changed the course of history, the reason for his failure was the conflict between political parties and the international community.

This study is the gateway to getting to know Abdul Karim Qasim's personality from the point of view of his opponents. In this two-part study, we discussed the beginnings of AbdulKarim Qasim's relations with political parties, and the views of the nationalist and communist parties towards Abdul-Karim Qasim, relying on several sources of different ideologies.
\end{abstract}

Key words: Party, July Revolution, Abdul-Karim Qasim, Communist, Free Officers. 


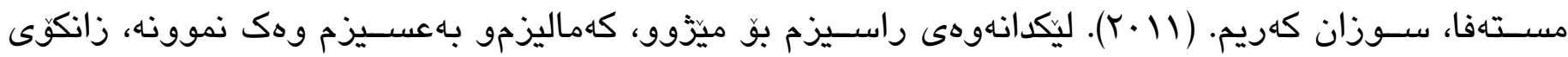

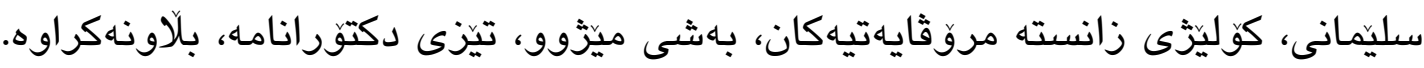

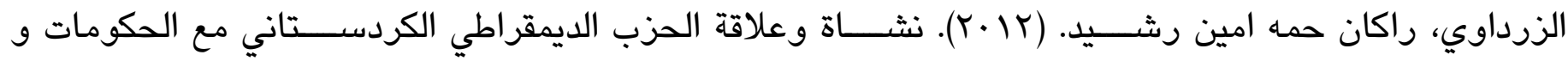

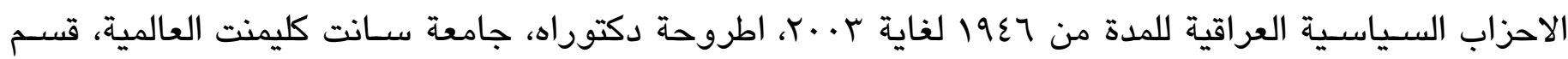
العلوم الانسانية. الركابي، قابل محسـن كاظم. (11 (1). الحياة الحزيية في العراق 1901- 1971، اطروحة دكتوراه مقدم الى جامعة سانت كليمنت العالمية.

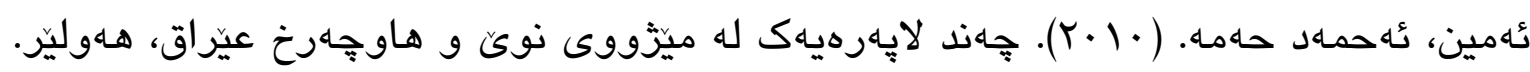

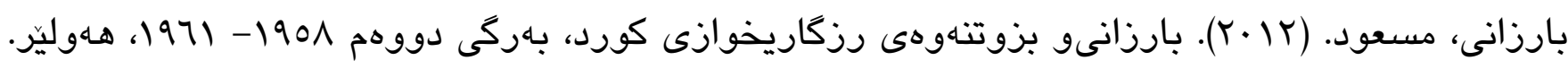

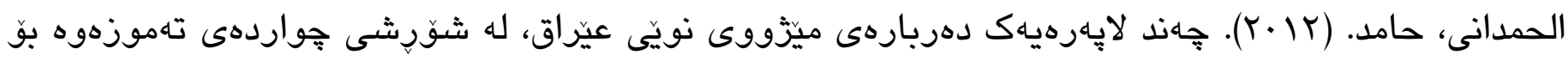
جهنكى دووهمى كهنداو، و/ شهالمال ئهممهد، سليمانى.

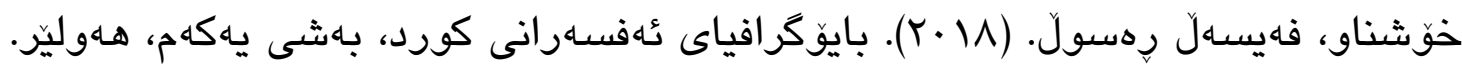

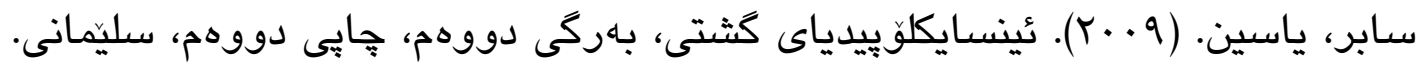

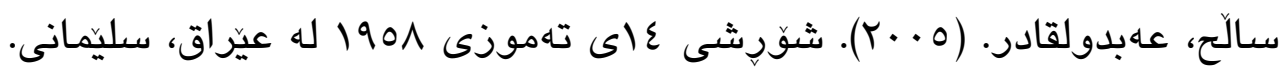
شيركو، فهرزهند. (V) . . (Y). عيراق قهيرانى عاسايشى ستراتيزى بنيانانهوهى، سليمانى. على، رهشيد محمد. (T . . ( ). عهبولكهريم قاسم له تهرازووى ويزداندا، سليمانى.

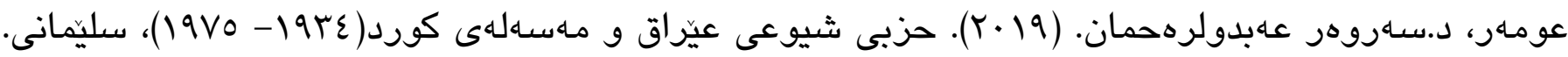

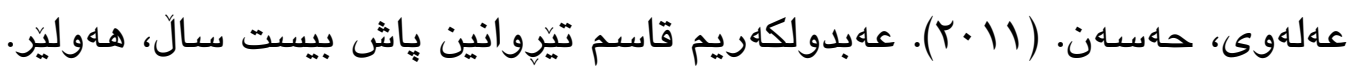

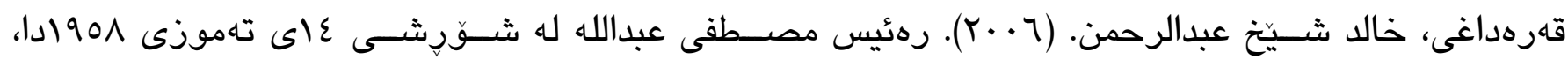
سبليمانى

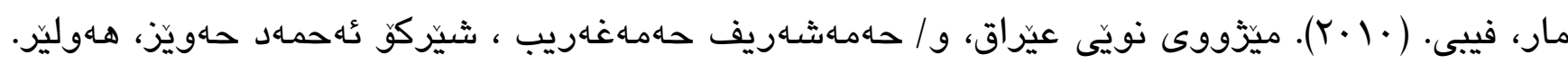

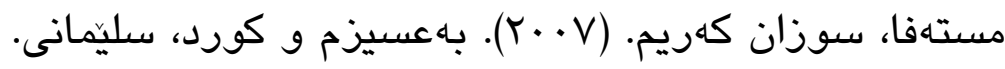

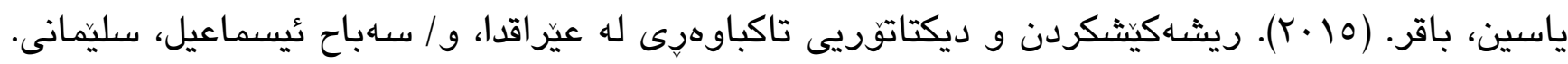
ابراهيم، ابراهيم محمد محمد. (1991). مقدمات الوحدة المصـرية السـورية بع 1901 1901، مطابع الهيئة المصـرية العامة للكتاب. احمد، د.ابراهيم خليل. (9199). جعفر عباس حميدي(الدكتور): تاريخ العراق المعاصر، الموصل. اعيان، احمد باش. (با. r). انقلاب عاتموز 1901 في العراق خلفياته وذيوله مع موجز عن العهد القاسمي 1901r 


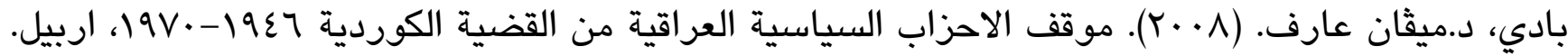

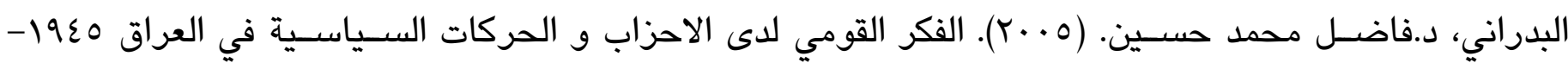
1901 بلدون اســم المؤلف. ( •197). مبادىء الثورة عا تموز في خطب ابن البار الزعيم عبدالكريم قاســم 1909، الجزء الثاني، جمهورية العراق. بطاطو، حنا. (9991). العراق، الشــيوعيون و البعثيون والضـــباط الاحرار، ت/ عفيف الرزاز، الكتاب الثالث، ط؟، بيروت.

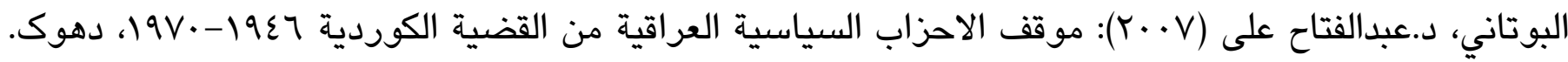
حديد، محمد. (T · ·ץ). مذكراتى، الصراع من اجل الديموقراطية في العراق، بيروت. حرفوش، اياد. (عا.با). الجمهورية العربية المتحدة حقائق الوحدة والاتفصال، دار عروية.

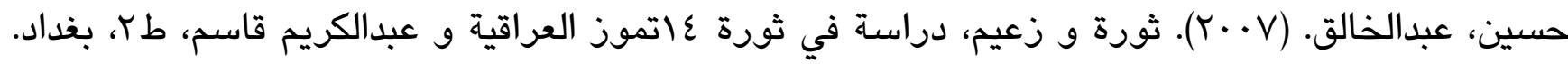

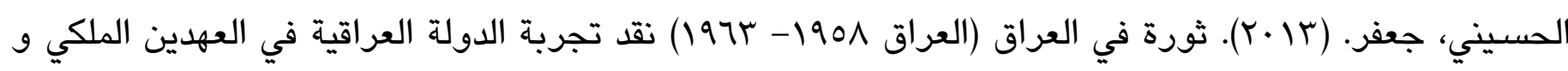
الجمهوري، بغداد. الحصري، خلدون ساطع. (rا97). ثورة عا تموز و حقيقة الثيوعيين في العراق، ط ب، بيروت.

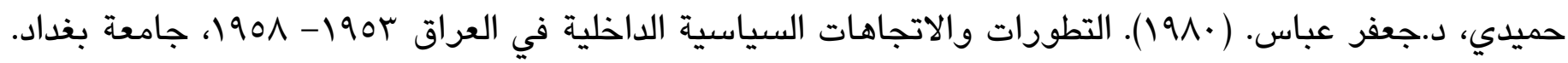

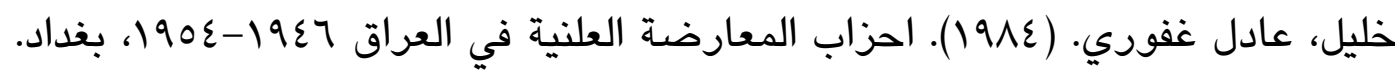
الدوري، سيف الدين. (• (·r). علي صالح السعدي، نائب رئيس الوزراء ووزير الداخلية و سلطة البعث الاولى في العراق س79 19، بيروت.

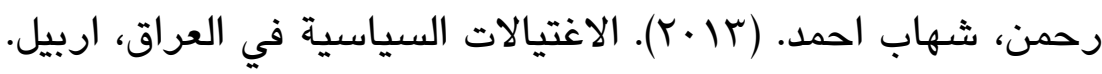
رشيد، د.عبدالوهاب حميد. (Y . .Y). العراق المعاصر، دمشق. الزبيدي، ليث عبدالحسن. (1911). ثوره عا تموز في العراق، طب، بغداد. السبع، د.جواد رضا (الدكتور): جماعة الاهالي وبرنامجهم في الديمقراطية الاجتماعية، كلية اداب، جامعة واسط.

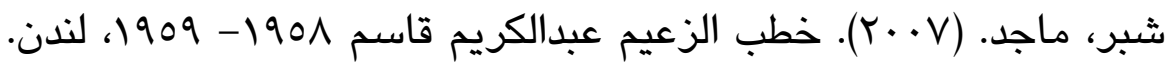

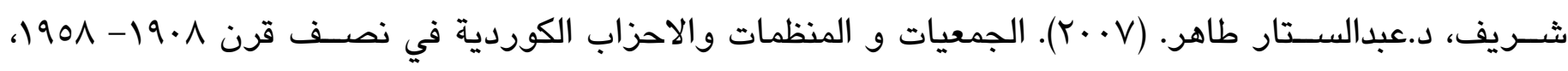
سليمانية. العاني، وسـيم رفعت عبدالمجيد. (IV) (Y). الزعيم الجاســوس، حقيقة الجاســوس الاســـائيلي الامريكي جمال عبدالناصر، بغداد. العگيلي، محمود جوار. (rا •r). ع اتموز ثوره وانحراف، بغداد. عليوي، هادي حسن. ( ( · (ץ). الاحزاب السياسية في العراق السرية و العلنية، بيروت. مردان، جمال مصطفى. (19199). عبدالكريم قاسم البداية و السقوط، بغداد. 
ناجي، د.طه. (9. . ץ): ثورة العراق المجيدة عا تموز 1901 و الرهان على العســكر، دار الرواد المزدهرة للطباعة و النشر.

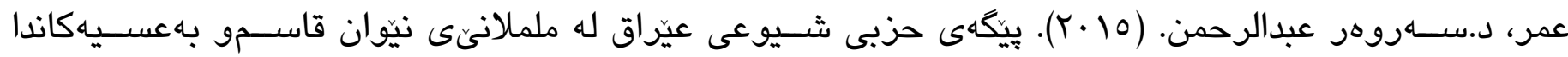

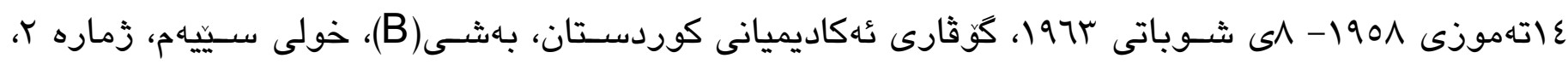
سبليمانى . محمد، نعيم جاسم ، دعاء الهادي محمد. (19 (Y). دور الشخصيات السياسية و العسكرية الموصلية في التطورات السياسية الداخلية في العراق(1901- r/197)، مجلة جامعة بابل للعلوم الانسانية، المجلد VY، العدده. عليوي، هادي حسن: علاقات عبدالكريم قاسـ بالآحزاب السياسية، العلاقات مع القوميين و البعثيين، حلقة الثالثة. .(WWW.kitabat.com)

عليوي، هادي حسن: القصة الكاملة لمحاولة فاشلة في اغتيال الزعيم عبدالكريم قاسم. (WWW.kitabat.com)

\section{هيلراويزّكان:}

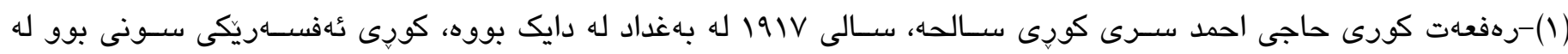

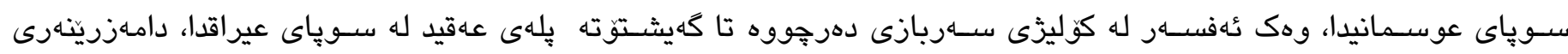

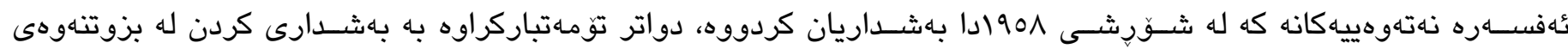

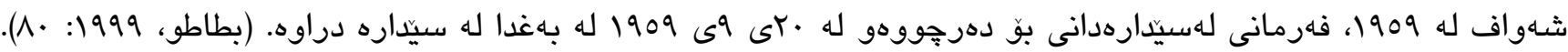
(Y)-ناوى تهواوى عهبدولكهريم قاســــ محهمهد بهكر زوبيديه، له شـــارى بهغداد له خيزّانيكى هـذزار لهدايك بووه، قوتابخانهى

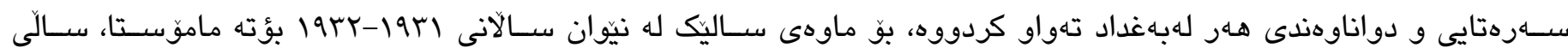

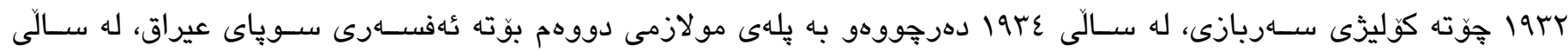

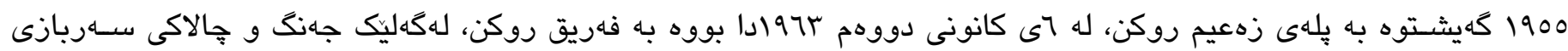
وهك فهلهستين، فورات، بارزان، زيّبار،...تاد بهشــاريكردووه، نيشـانهو مـدالياى ئازايهتى (وسـام الرافدين)ى وهركرتووه، لهكهل

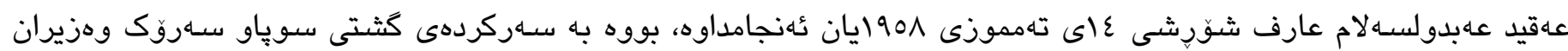
و وهزيرى بهركرى، لهماوهى ئهو جوار سـال و نيوهى دهسـلآتيدا كومهلّيك كارى باشـى ئهنجامداوه، له ئهنجامى كودهتاى ^ىى

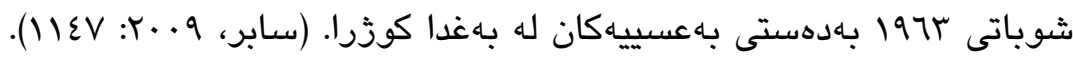

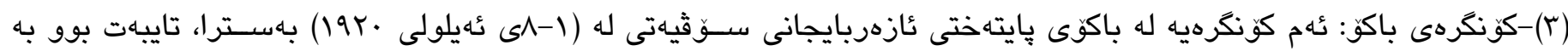

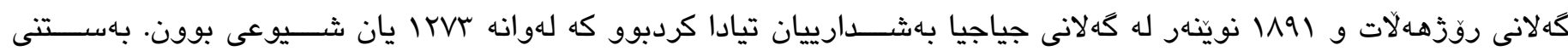




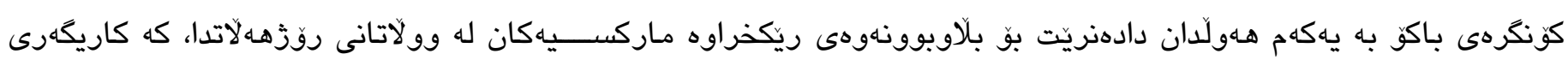
لهسهر جوتيارانى ميزوّيوّامياو سورياو لوينانو نيمجه دووركهى عهرهبى هـبوو، ئهويش به هاندانى نهتهوكانى ئهو نيّوجانه بوّ شوّرش كردن دزى دهسهلآتداريتى بهريتانياو فهرهنسا. سـهرهتاى درووست بوونى ريكخراوى ئهم بوّجوونه بوّ دواى درووست

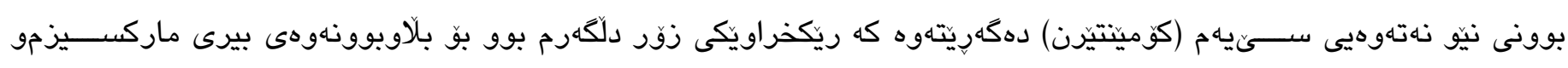

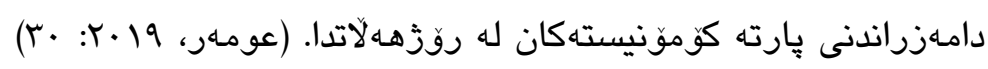

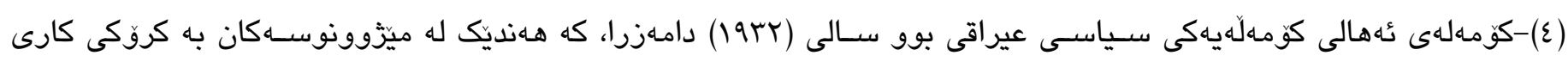

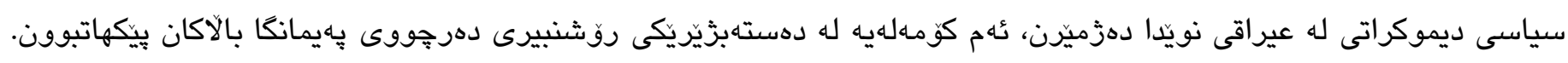

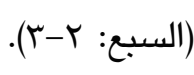
(0)-ئهو يهكيتيه نهتهوهييه بوو، كه له نيّوان كومارى ميسرو سوريا له يهكى شوباتى 1901 راكهيهندراو جهمال عهبدولناسر وهك

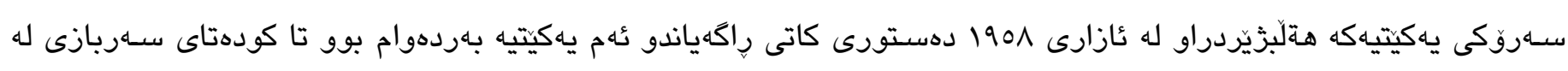

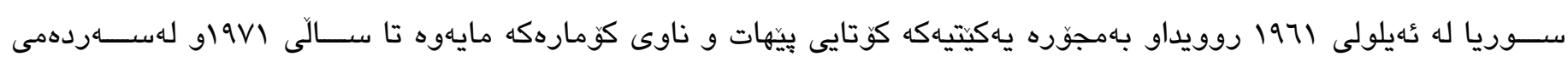

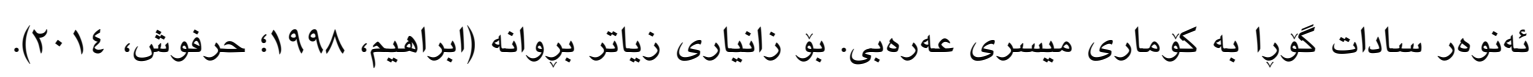

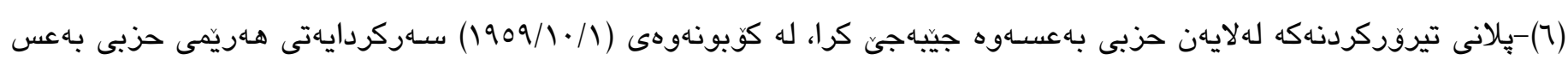

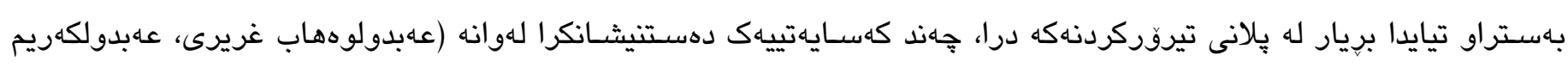

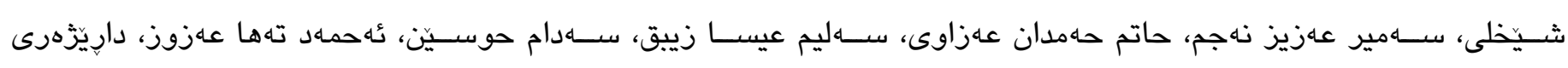

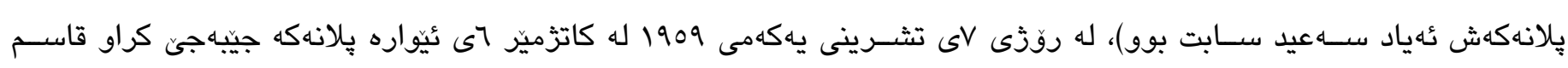

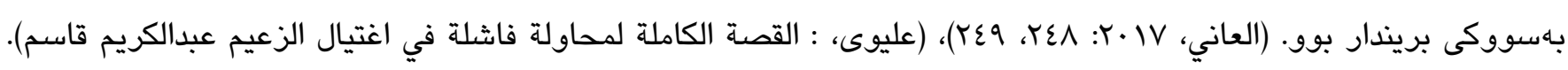
(V) و دايكيكى كوردى فهيلى شيعى لهدايك بووه. (بطاطو، 1999: MN). 